Article

\title{
Processability of Different Polymer Fractions Recovered from Mixed Wastes and Determination of Material Properties for Recycling
}

\author{
Selina Möllnitz ${ }^{1}{ }^{1}$, Michael Feuchter ${ }^{2}{ }^{\oplus}$, Ivica Duretek ${ }^{3}$, Gerald Schmidt ${ }^{4}{ }^{\oplus}$, Roland Pomberger ${ }^{1}$ \\ and Renato Sarc $1, *$ (i)
}

check for updates

Citation: Möllnitz, S.; Feuchter, M.; Duretek, I.; Schmidt, G.; Pomberger, R.; Sarc, R. Processability of Different Polymer Fractions Recovered from Mixed Wastes and Determination of Material Properties for Recycling.

Polymers 2021, 13, 457.

https:/ / doi.org/10.3390/ polym 13030457

Received: 12 January 2021

Accepted: 26 January 2021

Published: 31 January 2021

Publisher's Note: MDPI stays neutral with regard to jurisdictional claims in published maps and institutional affiliations.

Copyright: (c) 2021 by the authors. Licensee MDPI, Basel, Switzerland. This article is an open access article distributed under the terms and conditions of the Creative Commons Attribution (CC BY) license (https:// creativecommons.org/licenses/by/ $4.0 /)$
1 Department of Environmental and Energy Process Engineering, Chair of Waste Processing Technology and Waste Management, Montanuniversitaet Leoben-Franz-Josef-Straße 18, 8700 Leoben, Austria; selina.moellnitz@unileoben.ac.at (S.M.); roland.pomberger@unileoben.ac.at (R.P.)

2 Department of Polymer Engineering, Chair of Materials Science and Testing of Polymers, Montanuniversitaet Leoben-Otto Glöckel-Straße 2, 8700 Leoben, Austria; michael.feuchter@unileoben.ac.at

3 Department of Polymer Engineering, Chair of Polymer Processing, Montanuniversitaet Leoben-Otto Glöckel-Straße 2, 8700 Leoben, Austria; ivica.duretek@unileoben.ac.at

4 Saubermacher Dienstleistungs AG, Hans-Roth-Straße 1, 8073 Feldkirchen bei Graz, Austria; G.Schmidt@saubermacher.at

* Correspondence: renato.sarc@unileoben.ac.at; Tel.: +43-3842-402-5105

\begin{abstract}
To achieve future recycling targets and $\mathrm{CO}_{2}$ and waste reduction, the transfer of plastic contained in mixed waste from thermal recovery to mechanical recycling is a promising option. This requires extensive knowledge of the necessary processing depth of mixed wastes to enrich plastics and their processability in polymer processing machines. Also, the selection of a suitable processing method and product application area requires appropriate material behaviour. This paper investigates these aspects for a commercial processed, mixed waste, and two different mixed polyolefin fractions. The wastes are processed at different depths (e.g., washed/not washed, sorted into polyethylene, polypropylene, polyethylene terephthalate, polystyrene/unsorted) and then either homogenised in the extruder in advance or processed heterogeneously in the compression moulding process into plates. The produced recyclates in plate form are then subjected to mechanical, thermal, and rheological characterisation. Most investigated materials could be processed with simple compression moulding. The results show that an upstream washing process improves the achievable material properties, but homogenisation does not necessarily lead to an improvement. It was also found that a higher treatment depth (recovery of plastic types) is not necessary. The investigations show that plastic waste recovery with simple treatment from mixed, contaminated wastes into at least downcycling products is possible.
\end{abstract}

Keywords: mixed wastes; polymer recycling; processability; material characterisation; material properties; circular economy

\section{Introduction}

The waste management industry often talks about "plastics" as if it were a single material, but this is not the case. Plastics are an extensive family of entirely different materials. Each plastic type is designed with specific characteristics that make it ideal for its intended application. Whatever their application was, at the end of their service life, plastic materials are necessary resources that should first be recycled (upstream/downstream), and only when this is no longer technically possible and economically feasible, they should be used as an alternative energy source in energy recovery facilities [1-3].

In 2019, 368 million tonnes (Mt) of plastic were produced worldwide-57.9 Mt in Europe (EU28+NO/CH) [1], and the EU converters' demand was about 50.7 Mt. "Packaging" $(\sim 40 \%)$ and "building and construction" ( 20\%) represent the largest end-use markets 
followed by the "automotive industry" with about 10\% [4]. The most frequently used plastic types are the polyolefins (PO) (polyethylene-PE; polypropylene-PP) at approx. 50\% [4]. These are mainly used in the packaging sector, e.g., food packaging, hinged caps, bags, trays, films, and bottles, but also for pipes, automotive parts, agricultural films, houseware parts, etc. Other common packaging plastics are polyethylene terephthalate (PET) at about $8 \%$ and polystyrene (PS) at about 6.5\% [4]. The main areas of PET application are the production of fibres for the textile industry, moulding compounds, hollow bodies, and films, primarily for the packaging sector. Standard PS is mainly used to produce dimensionally stable food and other packaging products, e.g., cups, trays, caps, closures, boxes, and films. Expanded PS (EPS) and extruded PS (XPS) are also frequently used as insulation material for thermal insulation or impact sound insulation.

In 2018, 29.1 Mt plastic post-consumer waste was collected in the (EU28+NO/CH) [4], which ended up in three different waste management paths: $42.6 \%$ were used as SRF (solid recovered fuel) for energy recovery, $32.5 \%$ (81\% within the EU) were recycled, and $24.9 \%$ were still landfilled in Europe [4]. However, the figures for the last ten years show that waste management is currently transforming in Central Europe, especially in Austria. It is further developing from a thermal recovery to a recycling economy [5]. Nowadays, most plastics present in mixed wastes like commercial and municipal solid waste end up as SRF in energy recovery and are irrevocably lost for recycling [6]. Only PET in bottle form for recycling and PVC (polyvinyl chloride) parts are discharged, representing a contaminant for further processing. According to the EU [7], municipal solid waste recycling rates of $65 \%$ are to be achieved by 2035. In 2018, 86.1\% of mixed municipal solid waste (excluding bulky waste and separate collection) in Austria was treated thermally directly or after mechanicalbiological waste treatment, and $12.3 \%$ was treated biologically. Only $1.6 \%$, mainly metals and glass, were recycled [8]. The EU has released a plastic strategy that sets that by 2030, half of the plastic waste generated in the EU will be recycled. The sorting and recycling capacity has to be increased fourfold compared to the reference year 2015. Among others, future recycling rates can be met by upgrading relevant plastics from "Other recovery", e.g., "energy recovery", to "recycling" [3]. Recycled plastics are generally considered to be of lower quality than virgin plastics [1,2]. However, several key challenges need to be overcome. For a high recycled material quality, high purity of the input material is necessary, and external (e.g., glue) as well as internal impurities (e.g., adsorbed substances) must be removable. For pure, clean plastics, modern recycling processes can match virgin properties.

Nevertheless, many mixed waste streams (e.g., mixed commercial or municipal waste) are considered low value [9] and, therefore, not (economically) recyclable because of the high treatment costs or the high level of contamination [10]. Nevertheless, this does not mean that technical recycling is excluded. To investigate this, it is first of all necessary to determine whether a sufficient amount of plastic is contained in the mixed waste and whether separation is possible. If plastic mixtures or even individual types can be sorted out, the next step is to examine the processability with simple processing methods. If this is possible, a basic characterisation of the resulting materials follows. A suitable processing method can be selected only then, and the producible products can be determined [10].

The novelty of this research is the investigation of mixed, heterogenous, and contaminated (e.g., organic and inorganic impurities) mixtures with significant plastic amounts. Nowadays, such mixtures are declared as sorting residues (i.e., a non-recyclable fraction from material recovery facilities) and are utilised in energy recovery processes [10].

The plastic amount in the mixtures was investigated in two ways: on one side, at the polymer type (PE, PP, PET, and PS) level, and on the other side, as a varying mixture of unsorted polymers. Therefore, simple recoverability (i.e., sorting out with/without washing) and processability (i.e., compression moulding with/without homogenisation for production of recyclates) of the mentioned two ways were extensively investigated.

Next, the material properties of the plates produced from the recyclates were determined to create a material database for further research work in the linking of waste management with the plastic recycling sector. Finally, the applied strategy and the charac- 
terisation included have been widely studied and validated both at the industrial level and the research stage.

\section{Materials and Methods}

\subsection{Materials and Sampling}

A common mixed waste, i.e., SRF (approx. $200 \mathrm{~kg}$ ) produced from pre-treated and untreated mixed wastes (mixed municipal waste, commercial waste, etc., excluding separately collected wastes such as lightweight packaging waste) from a production facility near the city Graz in Austria, was used for the studies. In spring 2018, the sample was taken from the falling material stream according to ÖNORM S 2123-3 [11]. The material sample was taken from the SRF processing line after pre-shredding $(<500 \mathrm{~mm})$, magnetic separation, and PVC separation using a NIR (near-infrared) sorter and had a particle size $>100 \mathrm{~mm}$.

At the same time, about $20 \mathrm{~kg}$ of a sample of a PO-rich waste fraction (sample name: PO_A) was taken at the same plant. According to ÖNORM S 2123-3 [11], the sample was taken from the falling material stream. The sampling is carried out after pre-shredding, magnetic separation, PVC discharge, separation of heavy materials by a wind sifter, and subsequent post-shredding $(<35 \mathrm{~mm})$.

A further PO sample (approx. $8 \mathrm{~kg}$ ) (sample name: PO_B) was taken out from the wet-mechanical processing unit using a centrifugal force separator [12] with a particle size $<30 \mathrm{~mm}$. The input material was a mixture of common SRF, mixed plastics from light-weight packaging treatment, and mixed plastics from the industry.

All samples mentioned are representative samples composed of individual increments taken continuously over several hours during the plant operation or test run. Exemplary photos of the three test materials are shown in Figure A2 in Appendix I.

\subsection{Methods}

In this section, the experimental and analytical procedures are described. Figure 1 (I. Plant set up for investigations) shows the modular plant configuration for material preparation, as it could also look like in real processing plants. The investigation method is divided into three areas: A.) Mechanical pre-processing of the input materials; B.) Polymer processing consisting of material homogenisation, a compression moulding process, and test specimen preparation; and C.) Material characterisation with thermal, mechanical, and rheological material testing.

The mechanical pre-processing consists of a drum screen for the separation of fine material (<20 mm), a manual sorting station for the removal of non-plastics and other materials, a double shaft pre-shredder to reduce the average particle size of plastics below $100 \mathrm{~mm}$, a cold washing aggregate (a self-built stirred washer), a thermal drying cabinet (drying at $105^{\circ} \mathrm{C}$ up to constant weight according to ONR CEN/TS 15414-1), a sensor-based sorting system (near-infrared) for the manual sorting of the standard plastic types (PE, PP, PET, and PS), and a post-shredder (cutting mill) to reduce the particle size to $<4 \mathrm{~mm}$.

In the polymer processing step, one-half of the shredded plastic flakes per plastic type were fed to a counter-rotating parallel twin-screw extruder TSE 42/7D (screw diameter (D): 42 mm; screw length: 7D; model no.: 8324; type: Plasti-Corder PL2000 from Brabender ${ }^{\circledR}$ $\mathrm{GmbH} \&$ Co. KG, Duisburg, Germany) with a three-zone screw for thermoplastics. This equipment is used for material homogenisation, e.g., thermoplastic multicomponent systems, polymer blends, or composite materials. The product (filament) was cooled in a water bath and granulated afterwards. The other half of the materials were directly processed into plates (dimensions: $160 \mathrm{~mm} \times 160 \mathrm{~mm} \times 4 \mathrm{~mm}$ ) with a hot vacuum compression moulding process (vacuum press type P200PV, Dr. Collin GmbH, Maitenbeth, Germany). The material-specific four-zone temperature profile for material homogenisation is given in Table A3 in Appendix C. All materials were homogenised at a screw speed of $110 \mathrm{rpm}$. The material-specific, five-stage press profiles (temperature, pressure, and time) were determined empirically. The press profiles are presented in Table A4 in Appendix C. 


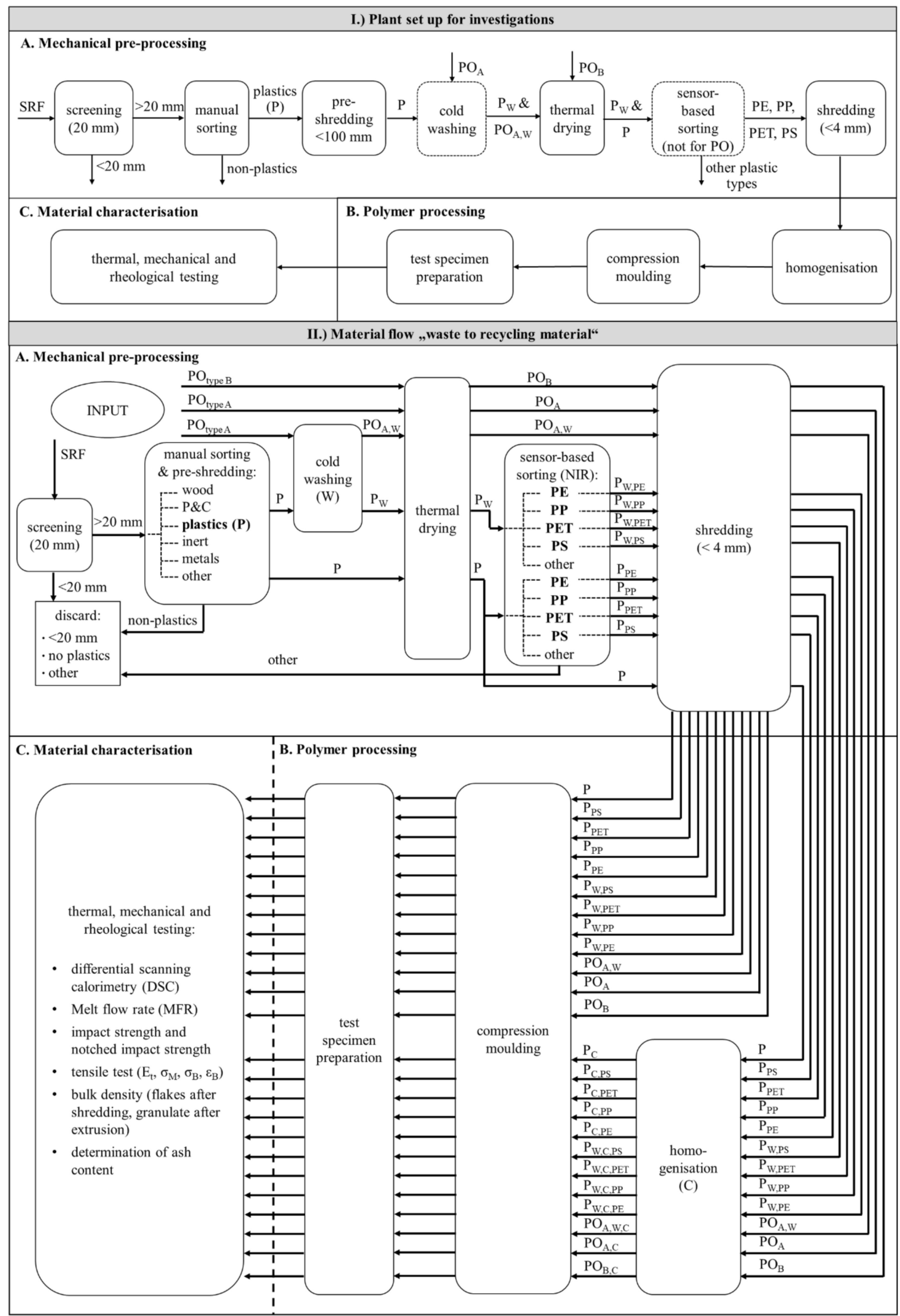

Figure 1. Flow chart for the plant set up of the investigations (I) and all material flows of input materials and resulting flows during the investigations (II); The process is divided into three sub-processes: A. Mechanical pre-processing, B. Polymer processing and $\mathbf{C}$. Material characterisation. 
Test specimens used for material characterisation were stamped or cut (CNC milling machine) from the plates. Extensive tests were carried out for this purpose: thermal characterisation with differential scanning calorimetry (DSC), melt mass flow rate (MFR), determination of ash content, mechanical characterisation with tensile tests, (notched) impact strength, and determination of the bulk density from plastic flakes after shredding and granulates after homogenisation.

Crystallinity $\left(X_{C}\right)$ is calculated from the melting enthalpy $\left(\Delta H_{m}\right)$ measured with DSC and the approximated melting enthalpy of totally crystalline material $\left(\Delta H_{0}\right)$ from the literature according to Equation (1) $[13,14]$.

$$
X_{C}=\frac{\Delta H_{m}}{\Delta H_{0}} \times 100 \%
$$

Figure 1 (II. Material flow "waste to recycling material") shows all material flows generated during the investigations from waste to finished test specimens.

The mixed waste, i.e., SRF, was the only input material screened and manually sorted into six material fractions (wood, paper, and cardboard (P\&C), plastics, inert, metals, and other materials). Exemplary photos of the manually sorted material fractions are shown in Appendix I in Figure A3. Only the plastic fraction was further processed and investigated. The other fractions were discarded and, therefore, not relevant for further investigation. The plastic fraction was divided into three similar parts. One part was dried and shredded without NIR sorting. The second part was dried and sorted by NIR into five plastic types and the rest. Exemplary photos of plastic types sorted with NIR are given in Appendix I in Figure A4. The third SRF part was washed, dried, and NIR-sorted. The sorted plastic types were post-shredded separately.

The two PO materials were not screened and not manually sorted due to their small grain size (i.e., $<35 \mathrm{~mm}$ and $<30 \mathrm{~mm}$ ).

The input material PO_A was divided into two similar parts. One part was washed, dried, and shredded. The other part was dried and shredded without a washing step. As the input material, PO_B came from wet-mechanical processing, it was only dried and shredded.

All material flows were divided after shredding. Half of each material went into the extruder for homogenisation, and the other half was compression moulded directly into test plates without homogenisation.

\section{C.) Material Characterisation}

For thermal characterisation of the materials, DSC measurements were performed using a DSC1 (Mettler-Toledo $\mathrm{GmbH}$, Urdorf, Switzerland) in a temperature range from 0 to $230{ }^{\circ} \mathrm{C}$ for PE, PP, and PS materials, and from 0 to $200{ }^{\circ} \mathrm{C}$ for $\mathrm{PO}$ and $\mathrm{P}$ materials with a heating rate of $10 \mathrm{~K} / \mathrm{min}$ in a nitrogen atmosphere (nitrogen flux rate $50 \mathrm{~mL} / \mathrm{min}$ ). The cooling rate was $20 \mathrm{~K} / \mathrm{min}$. To make the thermal history the same for all materials, a measuring program with one heating, one cooling, and second heating was chosen. Only the cooling and second heating curves were used for analysis. In advance, for checking the thermal stability, measurements up to $300{ }^{\circ} \mathrm{C}$ with a heating rate of $20 \mathrm{~K} / \mathrm{min}$ in a nitrogen atmosphere were carried out for each material. This was used to determine the range of measurement itself. Seven reproducibility measurements for the heterogeneous and three for the homogeneous materials were carried out according to DIN EN ISO 11357-1 [15]. Standard $40 \mu \mathrm{L}$ aluminum crucibles with pierced lids were used.

Charpy impact tests and notched impact tests (Ceast Resil 25, INSTRON/Ceast, Pianezza, Italy) according to DIN EN ISO179-1 [16] were performed at room temperature using a pendulum with $2 \mathrm{~J}$ (unnotched) and $0.5 \mathrm{~J}$ (notched) for P_PE, P_W,PE, P_W,C,PE, P_W,PP, P_W,C,PP, PO_A,W, and PO_B,C; a pendulum with $0.5 \mathrm{~J}$ (notched and unnotched) for P_PP, P_C,PP, all PS materials, PO_A, PO_A,C, PO_A,W,C, PO_B, and P; and a 7.5 J pendulum (unnotched) for P_W,C,PE. Tensile tests (Zwick Z010, Zwick/ Roell GmbH \& Co. KG, Ulm, Germany) were performed at room temperature according to DIN EN ISO 
527-1 [17] and EN ISO 527-2 [18]. The ash content was determined according to DIN EN ISO 3451-1 [19]. Due to the heterogeneity, three reproducibility measurements were carried out, and the mean values were calculated for the discussion. The bulk density was determined for the plastic flakes after shredding and for the granulates after compounding, respectively, according to DIN EN ISO 60 [20]. Five measurements per material were carried out. The MFR (Modular Melt (Mass) Flow Tester, INTERON/Ceast, I) was determined according to DIN EN ISO 1133-1 [21]. The test conditions were set to $190{ }^{\circ} \mathrm{C}$ and $2.16 \mathrm{~kg}$ for all materials except for the PS materials. For PS, the test conditions were set to $200^{\circ} \mathrm{C}$ and $5 \mathrm{~kg}$.

\section{Results}

For the examined plastic materials, the following properties were investigated: The composition of mixed waste, i.e., SRF and its plastic type content, thermal and mechanical properties, characterisation of the flow behaviour (MFR), bulk density, and ash content.

All stated values are wt.\% ${ }_{D S}$ (DS-dry substance), given in full percent only for clarity purposes.

All PE, PP, PO, and P materials could be processed without any major problems. The PS materials emitted much gas in both processing variants, and several test runs were necessary to find a stable processing method. The PET materials could neither be homogenised nor compression moulded due to excessive contamination. Possible impurities are multilayer bottles, residual label material (PO), different non-compatible PET grades [10], diffused substances, etc. The reasons for non-processability were not further investigated in this paper. All other materials could be processed. The plates made out of the heterogeneous materials showed flow directions (see Appendix I: Figures A7-A9). These are due to material accumulations in the compression moulding process.

\subsection{Total Composition of the Mixed Wastes and Plastic Type Content}

The composition of the input materials does not influence the subsequent investigations and is given here only to complete the information. Further extensive and current data on typical SRF composition are given by [22]. The detailed data of the investigated material are given in Appendix A.

Of the fine material ( $<20 \mathrm{~mm}$ ), $8.5 \% \mathrm{OS}$ (OS-original substance) was separated by pre-screening and discarded from SRF. The subsequent manual sorting analysis revealed the following composition of SRF $>20 \mathrm{~mm}$. The plastics represented the largest material fraction with $86.5 \%$ os. The other fraction (sorting residue and composites) represented $6.5 \% \mathrm{Os}$. The share of $\mathrm{P} \& \mathrm{C}$ was $5.8 \% \mathrm{Os}$. The share of metals and inert materials was $0.6 \% \mathrm{OS}$ each, and $0.1 \%$ os was the content of wood. The mass losses caused by material drying during storage, sorting losses (mobile organic material, dust formation, etc.), and screening losses were not taken into consideration for calculation here. These are in the range of $3 \%$ os of the total sample.

The sorted out plastic fraction $(86.5 \% \mathrm{OS}$, see above) consisted of the following plastic types. The PE fraction represented the largest share with $36.4 \%$ Os. The other fraction (black and other plastics as well as unidentified objects) represented $21.2 \%$ Os. The PET share was $20.7 \%_{\mathrm{OS}}$, and PP was contained with $15.7 \%_{\mathrm{OS}}$. The smallest fraction was PS with $6 \%_{\mathrm{OS}}$.

\subsection{Thermal Material Properties}

Table 1 displays the evaluations of the DSC measurements. Evaluated were the crystallisation temperature $\left(T_{C}\right)$ with respective crystallisation enthalpy $\left(\Delta \mathrm{H}_{\mathrm{c}}\right)$, melting temperatures $\left(\mathrm{T}_{\mathrm{m} 1}\right.$ and $\left.\mathrm{T}_{\mathrm{m} 2}\right)$ with respective melting enthalpy $\left(\Delta \mathrm{H}_{\mathrm{m} 1}\right.$ and $\left.\Delta \mathrm{H}_{\mathrm{m} 2}\right)$, and glass transition temperature $\left(\mathrm{T}_{\mathrm{g}}\right)$. A representative cooling curve and the second heating curve per analysed material for the respective material group (PE, PP, $\mathrm{PS}, \mathrm{PO}$, and $\mathrm{P}$ ) are shown in Appendix $\mathrm{B}$ for better illustration. 
Table 1. Results of the DSC measurements: crystallisation temperature $\left(T_{C}\right)$, crystallisation enthalpy $\left(\Delta H_{c}\right)$, melting temperatures $\left(\mathrm{T}_{\mathrm{m} 1}\right.$ and $\left.\mathrm{T}_{\mathrm{m} 2}\right)$, melting enthalpy $\left(\Delta \mathrm{H}_{\mathrm{m} 1}\right.$ and $\left.\Delta \mathrm{H}_{\mathrm{m} 2}\right)$, and glass transition temperature $\left(\mathrm{T}_{\mathrm{g}}\right)$.

\begin{tabular}{|c|c|c|c|c|c|c|c|}
\hline Parameters & $\mathbf{T}_{\mathrm{C}}$ & $\Delta \mathbf{H}_{\mathrm{c}}$ & $\mathrm{T}_{\mathrm{m} 1}$ & $\Delta \mathrm{H}_{\mathrm{m} 1}$ & $\mathrm{~T}_{\mathrm{m} 2}$ & $\Delta \mathrm{H}_{\mathrm{m} 2}$ & $T_{g}$ \\
\hline Material & $\left({ }^{\circ} \mathrm{C}\right)$ & $(\mathrm{J} / \mathrm{g})$ & $\left({ }^{\circ} \mathrm{C}\right)$ & $(\mathrm{J} / \mathrm{g})$ & $\left({ }^{\circ} \mathrm{C}\right)$ & $(\mathrm{J} / \mathrm{g})$ & $\left({ }^{\circ} \mathrm{C}\right)$ \\
\hline P_PE & $110.3 \pm 2.2$ & $115.8 \pm 18.6$ & $129.3 \pm 2.8$ & $94.4 \pm 18.6$ & $162.8 \pm 1.2$ & $4.8 \pm 4$ & - \\
\hline P_W,PE & $105.1 \pm 1.8$ & $118.9 \pm 8.2$ & $125.4 \pm 0.7$ & $97.1 \pm 10.4$ & $161.5 \pm 0.6$ & $4 \pm 1.4$ & - \\
\hline P_C,PE & $107.6 \pm 0.3$ & $109.7 \pm 4.8$ & $127.6 \pm 0.2$ & $80.9 \pm 2.3$ & $162.7 \pm 0.1$ & $4.5 \pm 0.2$ & - \\
\hline P_W,C,PE & $108.8 \pm 1.3$ & $128.3 \pm 3$ & $127.1 \pm 0.8$ & $98.7 \pm 1.8$ & - & - & - \\
\hline P_PP & $116 \pm 2.9$ & $86.7 \pm 8.8$ & $165.3 \pm 0.8$ & $74.2 \pm 11.2$ & - & - & - \\
\hline P_W,PP & $115.5 \pm 2.5$ & $91.8 \pm 2.7$ & $166.3 \pm 1$ & $79.6 \pm 6.9$ & - & - & - \\
\hline P_C,PP & $119.4 \pm 1.6$ & $83.5 \pm 4.1$ & $164 \pm 1$ & $47.6 \pm 18.3$ & $128.1 \pm 0.6$ & $6.1 \pm 0.2$ & - \\
\hline P_W,C,PP & $119 \pm 0.8$ & $83.5 \pm 2.1$ & $163.8 \pm 0.7$ & $63.6 \pm 0.5$ & - & - & - \\
\hline P_PS & $119.6 \pm 3.9$ & $10.4 \pm 8.9$ & $163.5 \pm 1.4$ & $7.7 \pm 9.5$ & - & - & $99.5 \pm 0.9$ \\
\hline P_W,PS & $113.4 \pm 3.5$ & $5.2 \pm 2.4$ & $162.2 \pm 0.9$ & $2.8 \pm 2.2$ & - & - & $98.9 \pm 1.6$ \\
\hline P_C,PS & $114 \pm 0.3$ & $7.7 \pm 0.9$ & $161.5 \pm 0.1$ & $4.5 \pm 0.3$ & - & - & $98.3 \pm 0.2$ \\
\hline P_W,C,PS & - & - & $161.9 \pm 0.1$ & $3.6 \pm 0.2$ & - & - & $98.9 \pm 0.4$ \\
\hline PO_A & $108.7 \pm 4.6$ & $74.1 \pm 18.9$ & $124.2 \pm 1.2$ & $46.1 \pm 14.9$ & $163.1 \pm 1.1$ & $13.7 \pm 4.2$ & - \\
\hline PO_A,W & $107.9 \pm 2.4$ & $81.1 \pm 4.6$ & $125.4 \pm 0.8$ & $50.8 \pm 4.8$ & $163.5 \pm 1.3$ & $15 \pm 4.6$ & - \\
\hline PO_A,C & $108.3 \pm 1.1$ & $83.8 \pm 0.3$ & $125.4 \pm 0.3$ & $50.2 \pm 2.9$ & $162 \pm 0.5$ & $15.1 \pm 0.2$ & - \\
\hline PO_A,W,C & $107.8 \pm 1.5$ & $86.6 \pm 3.2$ & $125.4 \pm 0.6$ & $51 \pm 0.5$ & $162 \pm 0.7$ & $17.5 \pm 1.4$ & - \\
\hline PO_B & $110.4 \pm 3.9$ & $105 \pm 10.3$ & $129 \pm 4.9$ & $54.6 \pm 12.4$ & $163.7 \pm 1$ & $18.8 \pm 3.9$ & - \\
\hline PO_B,C & $110.4 \pm 1.4$ & $110 \pm 1.5$ & $126.7 \pm 0.3$ & $61.9 \pm 3.1$ & $162 \pm 0.6$ & $22.1 \pm 0.9$ & - \\
\hline $\mathrm{P}$ & $111.2 \pm 1.8$ & $52.2 \pm 10.6$ & $128.2 \pm 6.9$ & $31.5 \pm 9.4$ & $164.2 \pm 1.2$ & $12 \pm 7.1$ & - \\
\hline P_C & $110.6 \pm 0.5$ & $67.3 \pm 2.4$ & $126.4 \pm 0.3$ & $39.6 \pm 3.1$ & $161.1 \pm 0.4$ & $13.1 \pm 0.3$ & - \\
\hline
\end{tabular}

The measured $\mathrm{T}_{\mathrm{C}}$ for the investigated PE materials is, on average, $108^{\circ} \mathrm{C}$. The calculation of the crystallinity for the PE materials according to $[13,14]$ with $293 \mathrm{~J} / \mathrm{g}$ for totally crystalline PE resulted in values between $36 \%$ and $38 \%$ for a cooling rate of $20 \mathrm{~K} / \mathrm{min}$. This is a comparatively low crystallinity for PE and corresponds to that for virgin (v)LLDPE $(10-50 \%)$ [23]. vLDPE typically has a crystallinity in the range of $45-55 \%$ and vHDPE in the range of $70-80 \%$ [23].

Two melting temperatures were determined for the PE materials. The primary melting point $\left(\mathrm{T}_{\mathrm{m} 1}\right)$ is that most of the material melts are between 125 and $129^{\circ} \mathrm{C}$. The measured secondary melting point $\mathrm{T}_{\mathrm{m} 2}$ is about $162^{\circ} \mathrm{C}$ and is due to contained impurities (higher melting foreign plastics such as PP, for example). Only P_W,PE shows a more distinct secondary melting point at approx. $110^{\circ} \mathrm{C}$. In the literature, melting temperature ranges for different vPE types are given as follows: $120-130{ }^{\circ} \mathrm{C}$ for LLDPE, $105-115^{\circ} \mathrm{C}$ for LDPE, and $128-136^{\circ} \mathrm{C}$ for HDPE [24]. It is interesting to note that the DSC curves are very similar, especially for the heterogeneous PE materials. As was to be expected, these become even more similar through homogenisation, which is evident in the smaller fluctuation margins.

The measured $\mathrm{T}_{\mathrm{C}}$ for the investigated PP materials is $117^{\circ} \mathrm{C}$ on average. According to $[13,14]$, the calculation of the crystallinity with $207 \mathrm{~J} / \mathrm{g}$ for totally crystalline PP yields values between $55 \%$ and $58 \%$ for a cooling rate of $20 \mathrm{~K} / \mathrm{min}$. This is a relatively high crystallinity for PP. Isotactic vPP has a crystallinity of 70-80\%, syndiotactic PP of 30-40\%, and atactic $\mathrm{PP}$ is amorphous and has no crystallinity $[23,25]$. The $\mathrm{T}_{\mathrm{m} 1}$ at approx. $165^{\circ} \mathrm{C}$ was determined for the PP materials. Only P_PP and $\mathrm{P}_{-} \mathrm{C}, \mathrm{PP}$ show a distinct $\mathrm{T}_{\mathrm{m} 2}$ at about $128^{\circ} \mathrm{C}$, which is due to contamination with foreign material, which can be removed by washing. In the literature, melting temperature ranges for vPP types are given between 161 and $186^{\circ} \mathrm{C}$ [26]. Likewise, the DSC curves of the heterogeneous PP materials are very similar and, after homogenisation, even closer to each other.

Both heating curves of all investigated PS materials show a continuous decrease over the measured temperature range. This corresponds to the literature, as PS has low heat resistance, and from $55{ }^{\circ} \mathrm{C}$ onwards, an acceleration of ageing starts, which is why PS is usually only used up to $70^{\circ} \mathrm{C}$ [27]. The measured $\mathrm{T}_{\mathrm{g}}$ is about $99^{\circ} \mathrm{C}$ on average, which corresponds to the literature value of about $80-100{ }^{\circ} \mathrm{C}$ for vPS $[24,25]$. The vPS types 
predominantly used are atactic and are, thus, in amorphous form and, therefore, have neither a $T_{C}$ nor a $T_{m}[24]$. Therefore, it is remarkable that both a $T_{C}\left(113-120{ }^{\circ} \mathrm{C}\right)$ and a $T_{m 1}$ $\left(161-164{ }^{\circ} \mathrm{C}\right)$ were measured for the PS materials. The melting temperature is $240^{\circ} \mathrm{C}$ [28] for isotactic vPS and $270{ }^{\circ} \mathrm{C}$ [28] for syndiotactic vPS. The heterogeneous PS materials' curves are much more heterogeneous compared to those of PE and PP and show more fluctuations and deviations from each other. Due to the homogenisation, these are smoothed considerably and are more similar to each other.

For the $\mathrm{PO}$ materials, a $\mathrm{T}_{\mathrm{C}}$ at approx. $108^{\circ} \mathrm{C}$, a distinct $\mathrm{T}_{\mathrm{m} 1}$ at approx. $125^{\circ} \mathrm{C}\left(\Delta \mathrm{H}_{\mathrm{m}}=50 \mathrm{~J} / \mathrm{g}\right)$, and a $\mathrm{T}_{\mathrm{m} 2}$ at approx. $163^{\circ} \mathrm{C}\left(\Delta \mathrm{H}_{\mathrm{m}}=15 \mathrm{~J} / \mathrm{g}\right)$ are measured. Furthermore, a further secondary melting temperature is measured at approx. $110^{\circ} \mathrm{C}$. This has already been observed with P_W,PE. With PO_B,C, it is evident compared to the other $\mathrm{PO}$ materials that $\mathrm{T}_{\mathrm{m} 1}$ is more distinct and the secondary melting temperature at $110^{\circ} \mathrm{C}$ is hardly present. Additionally, with PO_B,C, a second crystallisation peak at approx. $120^{\circ} \mathrm{C}$ becomes clear from the HDPE content [24]. The comparison of the curves of the $\mathrm{PO} \_\mathrm{A}$ materials shows major deviations only for the cooling curves. The other curves are very similar, especially those of the homogeneous PO_A materials. For PO_B, the 2nd heating curves also show major deviations from each other.

The mixed plastic fraction $(\mathbf{P})$ curves are surprisingly similar and show a high degree of similarity with those of PO materials. This is especially true for P_C and PO_B,C.

\subsection{Melt Mass Flow Rate}

Figure 2 shows a comparison of the mean MFR values of all materials investigated. The MFR results of all investigated materials are given in Appendix D.

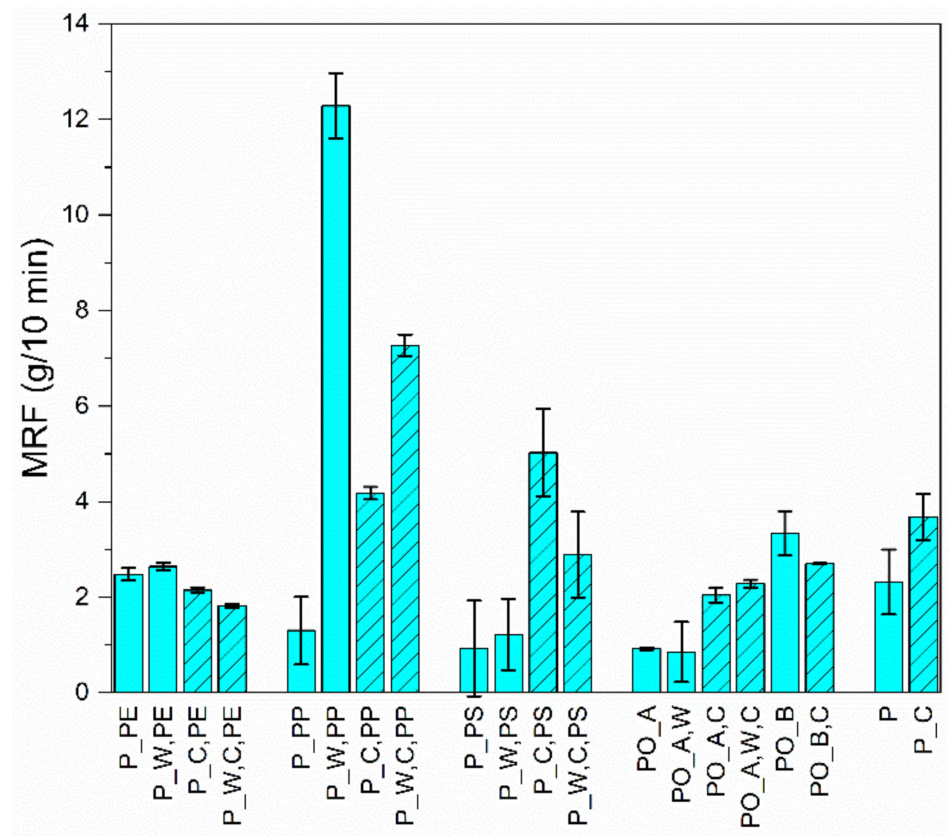

Figure 2. Averaged mass flow rate (MFR) values with standard deviation of all materials investigated.

\subsection{Mechanical Material Properties}

The measured MFR for the PE materials is between 1.8 and $2.6 \mathrm{~g} / 10 \mathrm{~min}$. These are very low values. In the literature, MFR values between 0.5 and $25 \mathrm{~g} / 10 \mathrm{~min}$ (test conditions: 190/2.16) are given for vLDPE and $0.35-17 \mathrm{~g} / 10 \mathrm{~min}$ for vHDPE [24]. These are surprisingly good values, which indicate low material damage and, thus, good processability. No influence of the washing process can be seen.

PP materials show a significant increase in MFR due to washing. Thus, the MFR of P_PP is increased by a factor of 12 for P_W,PP. The MFR for P_C,PP is higher by a factor of three than for P_PP. The homogenised PP materials also show that a $40 \%$ higher MFR is achieved by washing. During all PP sample measurements, outgassing of volatile 
components was observed, which pushed the sample upwards [29,30]. This leads to certain measurement uncertainties. The reasons for this have not been further investigated in this paper. In the literature, MFR values of 0.5-65 (test conditions: 190/5) are found for vPP [24]

The large fluctuation ranges of all PS materials can be explained by the measurement uncertainties caused by clogging of the nozzle after a certain time. This was observed in all PS samples and can be explained by contaminants with a higher melting temperature [29]. The two heterogeneous PS materials show low MFR values compared to the homogenised PS materials. P_W,C,PS shows a lower MFR than P_C,PS. In the literature, MFR values between 1.5 and $18 \mathrm{~g} / 10 \mathrm{~min}$ (test conditions: 200/5) are achieved for vPS [24]. Thus, the heterogeneous PS materials can be classified as very easy flowing and the homogeneous materials as normal flowing.

The heterogeneous PO_A materials show the lowest MFR values (below $1 \mathrm{~g} / 10 \mathrm{~min}$ ). There is no influence of washing on the MFR of the PO_A materials seen. Due to the homogenisation, the MFR rises to the MFR level of the PE materials. PO_B has a mean MFR of 3.3, which is reduced to 2.7 by homogenisation.

P has a mean MFR of 2.3, which is increased to 3.7 by homogenisation. The fluctuation ranges of the mean values can be explained by the measurement uncertainty caused by the outgassing of volatile components after a certain time $[29,30]$. The reasons for this have not been further investigated in this paper.

The tensile parameters, the Charpy impact strength $\left(\mathrm{a}_{\mathrm{CU}}\right)$, and the Charpy notched impact strength $\left(\mathrm{a}_{\mathrm{cN}}\right)$ are reported in Figure 3 for all materials. The results of the impact tests of all investigated materials are given in Appendix E, and the results of the tensile tests are given in Appendix F.

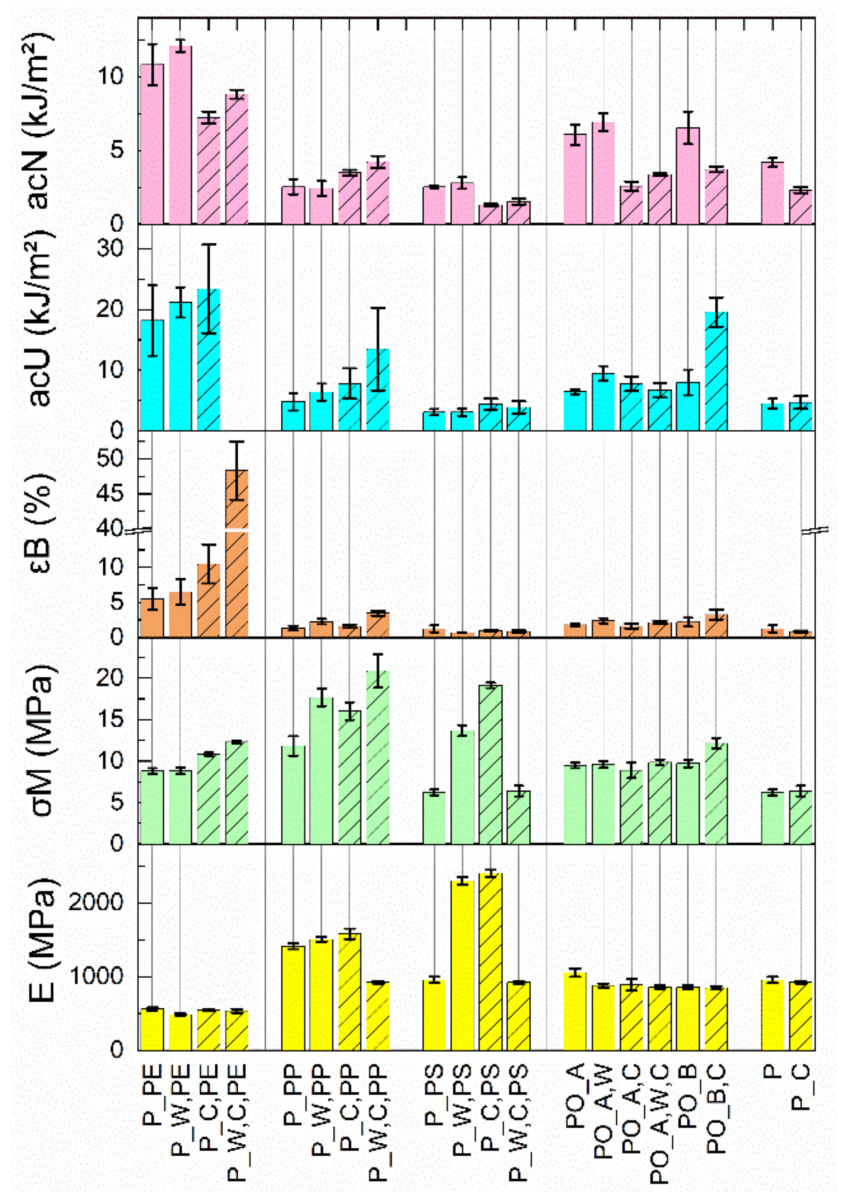

Figure 3. The results of the tensile tests $\left(\mathrm{E}, \sigma_{\mathrm{M}}, \varepsilon_{\mathrm{B}}\right)$, the Charpy impact strength $\left(\mathrm{a}_{\mathrm{cU}}\right)$, and the Charpy notched impact strength $\left(\mathrm{a}_{\mathrm{CN}}\right)$ for all materials investigated. 
Only P_W,C,PE displays plastic deformation with a well-defined yield point in the stress-strain curves [31]. P_PS, P_W,C,PP, P_PE, PO_A, and PO_A,C showed this behaviour only with single test specimens. The other materials showed mainly brittle behaviour [31].

The Young's modulus (E) is for all PE materials in a similar range around $530 \pm 40 \mathrm{MPa}$, and no significant influences due to washing or homogenisation can be detected. Comparison with data from the literature (vLDPE: 200 MPa; vHDPE: 1000 MPa) [24,31] shows that the achievable values are acceptable. According to the literature, $\mathrm{vPE}$ has the following tensile strengths $\left(\sigma_{\mathrm{M}}\right)$ and elongations at the yield point $\left(\varepsilon_{\mathrm{M}}\right)$ : vLDPE $-8-15 \mathrm{MPa}$ at $\sim 20 \%$; and vHDPE-20-30 MPa at $\sim 12 \%$ [24,31]. The literature gives elongations at break $\left(\varepsilon_{B}\right)$ of $400-800 \%$ [24]. The measured values for $\sigma_{M}$ correspond to those for vLDPE. However, both $\varepsilon_{M}$ and $\varepsilon_{B}$ are far below the literature values. The notched impact strength for all PE materials is in the range between 6 and $15 \mathrm{~kJ} / \mathrm{m}^{2}$. In the literature, values of about $6 \mathrm{kN} / \mathrm{m}^{2}$ or without a break are given for vPE $[24,31]$. For the impact strength, the literature predominantly states "no break". The examined PE materials are mostly only partially broken, and P_W,C,PE is not broken at all (see notes in Tables A6-A25 in Appendix E) [32].

The PP materials have Young's moduli ( 1500 MPa) almost three times higher than PE. Interestingly, $P_{-} W, C, P P$ is the lowest value of this material series at $923 \pm 19 \mathrm{MPa}$. Again, a comparison with the literature values (E: 1300-1800 MPa) [23,33] shows that these values are acceptable. For vPP, $\sigma_{\mathrm{M}}$ between 25 and $40 \mathrm{MPa}$ at $\varepsilon_{\mathrm{M}}$, around $20 \%$ [24], depending on the type, can be found in the literature. Depending on the vPP type, $\varepsilon_{B}$ of $200-900 \%$ is possible [24]. The measured $\sigma_{\mathrm{M}}$ for PP materials is below $25 \mathrm{MPa}$, and only an $\varepsilon_{\mathrm{B}}$ of $2.5 \pm 0.4 \%$ was measured. As with the PE materials, this indicates significant material embrittlement. The impact strength determined for the PP materials is below $20 \mathrm{~kJ} / \mathrm{m}^{2}$, which corresponds to the literature values [24]. The $\mathrm{a}_{\mathrm{cN}}$ determined is between 2 and $5 \mathrm{~kJ} / \mathrm{m}^{2}$, which is slightly below the literature's values (vPP: $4-12 \mathrm{~kJ} / \mathrm{m}^{2}$ ) [24].

The Young's modulus of P_PS ( $\sim 955 \mathrm{MPa})$ shows a sharp increase to $\sim 2300 \mathrm{MPa}$ for P_W,PS and about $2400 \mathrm{MPa}$ for P_C,PS and thus, are the highest values of all materials examined. However, the combination of washing and homogenisation causes E ( $923 \mathrm{MPa})$ to drop even below the initial value of P_PS. In the literature, values between 2200 and $3300 \mathrm{MPa}$ [24] are given for vPS. For vPS, $\sigma_{\mathrm{B}}$ between 45 and $65 \mathrm{MPa} / \mathrm{mm}^{2}$ and 3 and $4 \%$ for $\varepsilon_{\mathrm{B}}$ are found in the literature [24,33]. The measured $\mathrm{a}_{\mathrm{CU}}$ of the PS materials is below $5 \mathrm{~kJ} / \mathrm{m}^{2}$ and below the values found in the literature $\left(5-20 \mathrm{~kJ} / \mathrm{mm}^{2}\right)$ for vPS $[31,33]$. The $\mathrm{a}_{\mathrm{cN}}$ of the PS materials are between 1 and $2.5 \mathrm{~kJ} / \mathrm{m}^{2}$, and this is in the field of the literature values (vPS: $2.0 \mathrm{~kJ} / \mathrm{m}^{2}$ ) [24].

Except for PO_A (1,053 $\pm 56 \mathrm{MPa})$, the PO materials have very similar Young's moduli between 830 and $900 \mathrm{MPa}$. Significant influences due to washing or homogenisation are not recognisable. The Young's moduli of the P and P_C material ( 940 MPa) are also very similar, and no influence of homogenisation can be seen.

The values of $\sigma_{M}$ and $\varepsilon_{B}$ increases due to the homogenisation of PE, PP, and PO_B materials. With PS, a significant increase is measured of $\sigma_{\mathrm{M}}$ and $\varepsilon_{\mathrm{M}}$ by washing or compounding, but in combination, no significant change to P_PS is observed. The PO_A materials all show very similar values for $\sigma_{M}$ and $\varepsilon_{M}$, with the higher values for PO_A,W,C being achieved.

\subsection{Ash Content}

Figure 4 shows the ash contents (AC) of all investigated materials. The results of the ash content measurements of all investigated materials are given in Appendix $\mathrm{H}$.

The AC for the PE materials decreases for both the heterogeneous and the homogeneous fraction from about $4 \%$ to $2.4 \%$ by about $40 \%$ due to the washing process. For the two heterogeneous PP materials, no influence of the washing on the AC of about $2.4 \%$ was observed. In the homogenised PP fraction, the AC decreases by approx. $40 \%$ from $2.7 \%$ to $1.7 \%$ due to washing. The AC of the PS and PO_A materials has been reduced by approx. $30 \%$ for both the heterogeneous and the homogeneous fraction by washing. The unwashed PO_A materials have the second-highest AC of all investigated materials. The average AC for the PO_B is $2.2 \%$, and for PO_B,C 2.5\%. The lower contents compared to PO_A can be 
explained by the cleaner input materials (e.g., pre-sorted mixed plastic fraction) used for PO_B production. As expected, the unwashed, unsorted mixed plastic fraction $(\mathrm{P})$ has the highest AC (approx. $8.4 \%$ for $\mathrm{P}$ and $6.2 \%$ for $\mathrm{P}_{-} \mathrm{C}$ ) since there was no surface cleaning by washing or losing fine material, e.g., by sorting.

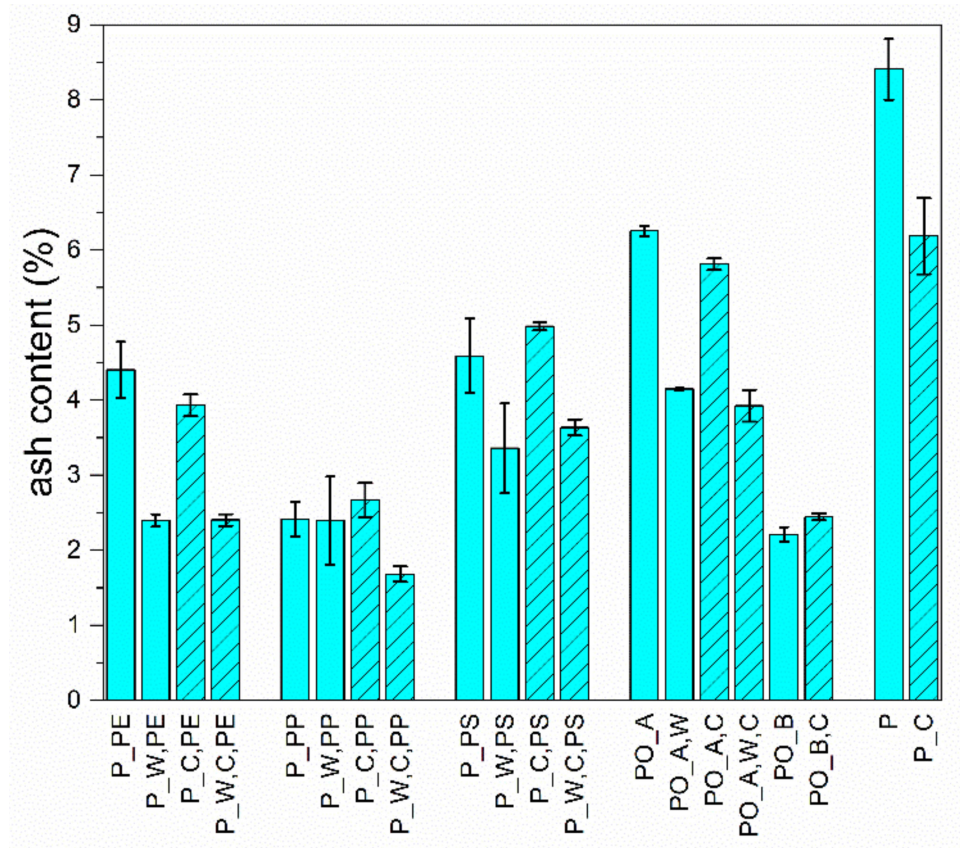

Figure 4. Calculated ash contents of all investigated materials.

\subsection{Bulk Densities}

The determined bulk densities of all materials are shown in Figure 5 before (flakes $<4 \mathrm{~mm}$ ) and after homogenisation (granulates). The results of the bulk densities of all investigated materials are given in Appendix G. Exemplary photos of the produced flakes (Figure A5), and granulates (Figure A6) are given in Appendix I.

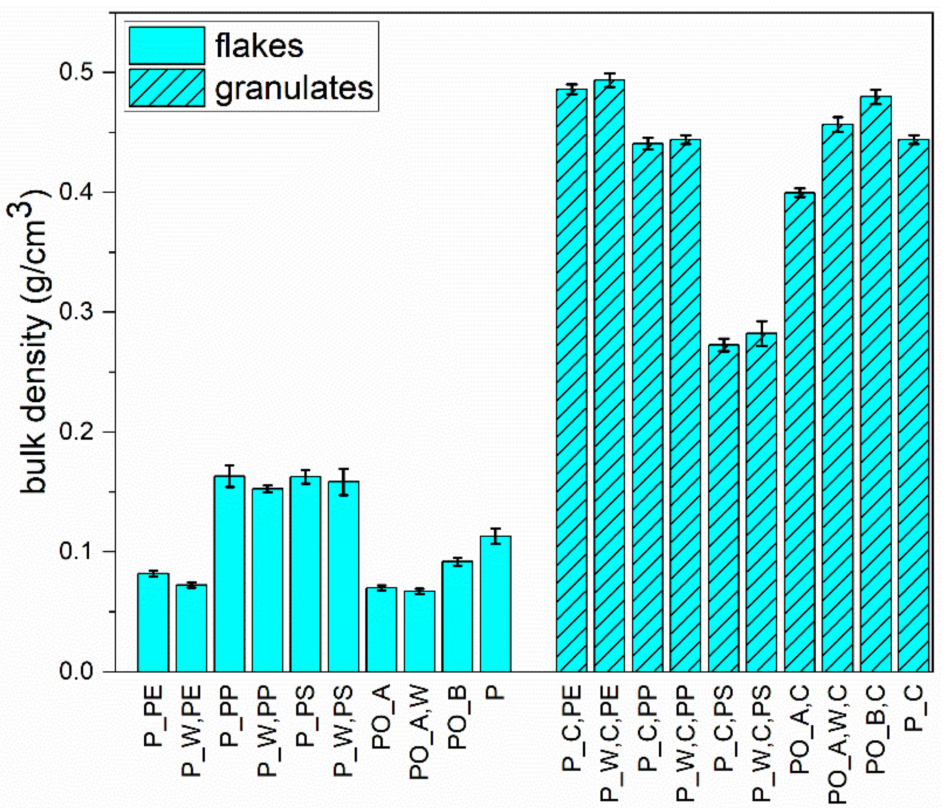

Figure 5. Determined bulk densities of all investigated materials before (flakes $<4 \mathrm{~mm}$ ) and after homogenisation (granulates). 


\subsubsection{Flakes}

As expected, the bulk densities of all flakes are lower than those of the granules. The PE flakes have a bulk density of $0.082 \pm 0.0023 \mathrm{~g} / \mathrm{cm}^{3}$ (P_PE) and $0.072 \pm 0.0022 \mathrm{~g} / \mathrm{cm}^{3}$ (P_W,PE). The PP and PS flakes have a bulk density of approx. $0.16 \mathrm{~g} / \mathrm{cm}^{3}$, almost twice as high. For PP, this can be explained by the higher proportion of compacted, threedimensional particles, although vPP $\left(0.895-0.91 \mathrm{~g} / \mathrm{cm}^{3}\right)$ is in the same material density range as vPE $\left(0.87-0.97 \mathrm{~g} / \mathrm{cm}^{3}\right)$ [24]. The PE flakes consist mainly of flat, thin, twodimensional particles, although vPS has a higher material density $\left(0.104-0.109 \mathrm{~g} / \mathrm{cm}^{3}\right)$ [24] than vPE or vPP, and 2D particles are less common. Nevertheless, PS can occur in an expanded form (EPS: $0.0015-0.009 \mathrm{~g} / \mathrm{cm}^{3}$ ) [31], which would significantly reduce the bulk density. The PO_A flakes have a bulk density of about $0.07 \mathrm{~g} / \mathrm{cm}^{3}$. This suggests that the flakes contain a high proportion of mainly PE films. The bulk density of PO_B is $0.092 \mathrm{~g} / \mathrm{cm}^{3}$ and of $P$ is $0.113 \mathrm{~g} / \mathrm{cm}^{3}$. No feeding problems (e.g., bridge formation) were observed for the flakes of all materials.

\subsubsection{Granulates}

The homogeneous PE granulates have the highest bulk density with $0.49 \mathrm{~g} / \mathrm{cm}^{3}$. The PP granulates have a bulk density of $0.44 \mathrm{~g} / \mathrm{cm}^{3}$. The PS granulates have the lowest bulk density of the homogeneous materials with approx. $0.27 \mathrm{~g} / \mathrm{cm}^{3}$. This can be explained by the fact that degradation processes caused increased outgassing during extrusion, which could not be sufficiently removed (see Figure A6 in Appendix I). Additionally, the different bulk densities of PO_A,C $\left(0.4 \mathrm{~g} / \mathrm{cm}^{3}\right)$ and PO_A,W,C $\left(0.46 \mathrm{~g} / \mathrm{cm}^{3}\right)$ can be explained in this way. The bulk density of PO_B,C was the second highest with $0.48 \mathrm{~g} / \mathrm{cm}^{3}$. P_C had a bulk density of $0.44 \mathrm{~g} / \mathrm{cm}^{3}$. Commercially available plastic granulates have a bulk density between 0.5 and $0.9 \mathrm{~g} / \mathrm{cm}^{3}$ [32]. No feeding problems (e.g., bridge formation) were observed for the granulates produced from all materials.

\section{Discussion}

The degree of crystallinity of polymers is directly related to their material properties: the more crystalline a polymer is, the harder and more brittle it is, and dimensional stability and melting point or softening point increase because intermolecular forces can act more effectively due to the more uniform arrangement of the molecules [13,22]. Despite the low crystallinity (36-38\%), the PE materials examined, except for P_W,C,PE, show predominantly brittle material behaviour. Since a washing process somewhat improves the mechanical properties, it can be concluded that these are mainly impurities that negatively influence the material properties and that material ageing plays a subordinate role. Likewise, the distinct, second melting temperature at about $128^{\circ} \mathrm{C}$ for P_PP and P_C,PP can be explained by the presence of organic impurities (e.g., other plastics with a density $>1 \mathrm{~g} / \mathrm{cm}^{3}$ ), which can also be removed by washing. Therefore, $\mathrm{T}_{\mathrm{C}}$ and $\mathrm{T}_{\mathrm{m} 1}$ of the PS materials can only be explained by contained organic impurities, e.g., PP.

The DSC curve progressions of the investigated PO materials as well as the determined values of $\mathrm{T}_{\mathrm{C}}$ and a distinct $\mathrm{T}_{\mathrm{m} 1}$ at approx. $125^{\circ} \mathrm{C}$ and a $\mathrm{T}_{\mathrm{m} 2}$ at approx. $163{ }^{\circ} \mathrm{C}$ indicate a higher PE than PP content of the PO materials. The melting temperature at approx. $110^{\circ} \mathrm{C}$ of some $\mathrm{PO}$ materials and P_W,PE can be attributed to organic impurities or a higher LDPE content. A second crystallisation peak at approx. $120^{\circ} \mathrm{C}$ for PO_B,C becomes clear from the HDPE content [34]. This and the higher $\Delta \mathrm{H}_{\mathrm{m}}$ of $\mathrm{T}_{\mathrm{m} 2}$ allow the assumption of a somewhat higher PP content than in PO_A. The similar DSC curves of mixed plastics $(\mathrm{P})$ to the investigated $\mathrm{PO}$ materials lead to the hypothesis that most investigated P materials consist of PO. This indicates that a separation, and separate PE, PP, and PO processing is not necessary since the thermal properties do not change significantly.

The MFR results are surprisingly good for almost all materials examined, which indicate low material damage and thus, good processability. Depending on the material (high or low viscosity), suitable processing methods must be selected. The investigated $\mathrm{PO}$ and P materials have similar MRF values to the investigated PE materials. From this, 
it can be concluded for the MFR that a separation of the PE materials out of mixed plastics is not mandatory.

Except for the very brittle PS materials, all other materials investigated have surprisingly good mechanical properties. The mechanical characteristics show that wet processing, combined with a homogenisation step, does not necessarily lead to an improvement in mechanical properties. Most of the investigated materials show a clear decrease in mechanical properties compared to virgin homopolymers known from the literature. This indicates the existence of organic and inorganic impurities as well as material degradation due to ageing [35].

The investigations on the ash content of the materials show high inorganic contents, which are mostly significantly reduced by washing. These inorganic impurities are a plausible explanation for the observed deviations between the washed and unwashed materials. Additionally, a short service life ( $<1$ year) is to be expected for the plastics in the wastes examined. It is therefore assumed that material ageing plays only a minor role. A part of the $\mathrm{AC}$ is due to inorganic fillers (e.g., glass fibres, silicates, oxides, and hydroxides) in the polymer matrix. Thus, despite the comparatively high ash contents (3-8\%), the PO and P materials investigated show a good mechanical property profile. This suggests that the inorganic impurities contained act to a certain extent as a reinforcing material.

Knowledge of the bulk density of free-flowing materials is an essential parameter for the design of storage, transport, and dosing equipment. The bulk density is also essential for the material feed behaviour and the pressure build-up in solid conveying areas of extruders or injection moulding machines [36]. It should be noted that the pelletising system's settings and the melt strand temperature have a significant influence on the pellet geometry and, thus, on the bulk density [31]. Commercially available plastic granulates have a bulk density between 0.5 and $0.9 \mathrm{~g} / \mathrm{cm}^{3}$ [33]. As the granulate bulk densities determined are only slightly lower, with the exception of P_C,PS, and P_W,C,PS, it is assumed that these materials have good conveying and feeding properties. No feeding problems (e.g., bridging) occurred with the flakes and granulates produced from all materials.

\section{Conclusions}

The investigations have shown that all waste materials could be processed into plasticrich fractions with a grain size $<4 \mathrm{~mm}$ using simple waste treatment without any significant problems. The processing of the different plastic fractions with simple compression moulding showed that all PE, PP, PO, and P materials could be processed without any major problems. This, together with the low MFR values, suggests that conventional extrusion into semi-finished products such as pipes or plates could be technically possible. A list of potential products for the materials investigated is given in Appendix J. The injection moulding process must be tested, and investigations must be carried out with a high-pressure capillary rheometer. Furthermore, thermogravimetric (TGA) and Fouriertransform infrared (FTIR) analysis to determine chemical structure changes possible for polymeric waste during the technological process of the materials is recommended for future investigations. The PS materials emitted gas in both processing variants, and several test runs were necessary to find a stable processing method. Therefore, an evaluation of volatile organic compound emissions from the materials is necessary if they would be implemented in industrial processes. The PET materials could neither be homogenised nor compression moulded due to excessive contamination.

In some cases, the material properties determined are (Young's modulus, impact strength) clearly below those of virgin polymers. This limits the product range that can be manufactured and its range of applications. The results also show that an upstream washing process improves the achievable properties, but homogenisation does not necessarily improve properties. It was also found that a higher treatment depth (recovery of plastic types) from mixed wastes is not necessary since the $\mathrm{PO}$ and mixed plastics fractions showed similarly good material data with good processability. 
In summary, the investigations show that the recovery and simple treatment of plastics from mixed, contaminated wastes into at least downcycling products seems to be possible. The transfer of used plastics from thermal recovery to recycling could make an important contribution to achieving additional recycling targets, resource conservation, and $\mathrm{CO}_{2}$ and waste reduction.

Author Contributions: Conceptualization, S.M.; methodology, S.M.; validation, M.F. and I.D.; formal analysis, S.M.; investigation, S.M., M.F. and I.D.; resources, M.F., I.D. and G.S.; data curation, S.M., M.F. and I.D.; writing—original draft preparation, S.M.; writing—review and editing, M.F., I.D., G.S., R.P. and R.S.; visualization, S.M.; supervision, R.S.; project administration, S.M.; funding acquisition, R.P. and R.S. All authors have read and agreed to the published version of the manuscript.

Funding: Partial funding for this work was provided by: The Center of Competence for Recycling and Recovery of Waste 4.0 (acronym ReWaste4.0) (contract number 860884 ) under the scope of the COMET—Competence Centers for Excellent Technologies—financially supported by BMK, BMDW, and the federal states of Styria, managed by the FFG.

Institutional Review Board Statement: Not applicable.

Informed Consent Statement: Not applicable.

Data Availability Statement: Not applicable.

Acknowledgments: The authors would like to thank their student Anna-Lisa Lanthaler who actively supported the execution of experiments. We express our thanks also to the proofreader, Thomas Lucyshyn and Lisa Kandlbauer for the graphic support.

Conflicts of Interest: The authors declare that they have no known competing financial interests or personal relationships that could have appeared to influence the work reported in this paper. We express our thanks also to the project partners who contributed significantly to the successful completion of the test series with their equipment and infrastructure.

\section{Abbreviations}

$\begin{array}{ll}\text { Abbreviation } & \text { Description } \\ \Delta \mathrm{H}_{\mathrm{C}} & \text { crystallisation enthalpy } \\ \Delta \mathrm{H}_{\mathrm{m}} & \text { melting enthalpy } \\ \varepsilon_{\mathrm{B}} & \text { elongation at break } \\ \varepsilon_{\mathrm{M}} & \text { maximum elongation at the yield point } \\ \sigma_{\mathrm{B}} & \text { tensile strength at break } \\ \sigma_{\mathrm{M}} & \text { maximum tensile strength } \\ \mathrm{AC} & \text { ash content } \\ \mathrm{a}_{\mathrm{cN}} & \text { notched impact strength } \\ \mathrm{a}_{\mathrm{CU}} & \text { impact strength } \\ \mathrm{C} & \text { homogenised } \\ \mathrm{CO} & \text { carbon dioxide-greenhouse gas } \\ \mathrm{D} & \text { screw diameter } \\ \mathrm{DS} & \text { dry substance } \\ \mathrm{DSC} & \text { differential scanning calorimetry } \\ \mathrm{E} & \text { Young's modulus } \\ \text { e.g., } & \text { for example } \\ \text { EPS } & \text { expanded polystyrene } \\ \text { EU } & \text { European Union } \\ \text { FTIR } & \text { Fourier-transform infrared } \\ \text { HDPE } & \text { high-density polyethylene } \\ \text { LDPE } & \text { low-density polyethylene } \\ \text { LLDPE } & \text { linear low-density polyethylene } \\ \text { min } & \text { minutes } \\ \text { MFR } & \text { melt (mass) flow rate } \\ \text { Mt } & \text { million tonnes } \\ \text { NIR } & \text { near-infrared } \\ & \end{array}$




$\begin{array}{ll}\text { Abbreviation } & \begin{array}{l}\text { Description } \\ \text { original substance }\end{array} \\ \text { P } & \text { plastics } \\ \text { P\&C } & \text { paper and cardboard } \\ \text { PO } & \text { polyolefins } \\ \text { (v)PE } & \text { virgin) polyethylene } \\ \text { PET } & \text { polyethylene terephthalate } \\ \text { PP } & \text { polypropylene } \\ \text { PS } & \text { polystyrene } \\ \text { PVC } & \text { polyvinyl chloride } \\ \text { rpm } & \text { revolutions per minute } \\ \text { SRF } & \text { solid recovered fuel } \\ T_{C} & \text { crystallisation temperature } \\ T_{g} & \text { glass transition temperature } \\ T_{m} & \text { melting temperature } \\ \text { TSE } & \text { twin-screw extruder } \\ \text { v } & \text { virgin } \\ \text { W } & \text { washed }\end{array}$

\section{Appendix A. Total Composition of SRF and Plastic Type Content}

Table A1. Total composition of SRF determined by manual sorting analysis (Note: fine fraction $<20$ $(8.5 \%) \mathrm{mm}$ was separated and is not considered in the table).

\begin{tabular}{ccc}
\hline Fraction & $\begin{array}{c}\text { Mass } \\
(\mathbf{k g})\end{array}$ & $\begin{array}{c}\text { Mass } \\
(\mathbf{\%})\end{array}$ \\
\hline Plastics & 150.4 & 86.5 \\
Metals & 1.01 & 0.6 \\
P\&C 1 & 10.03 & 5.8 \\
Inert & 1.04 & 0.6 \\
Wood & 0.17 & 0.1 \\
Other & 11.27 & 6.5 \\
Total & 173.92 & 100 \\
\hline
\end{tabular}

${ }^{1}$ P\&C: paper and cardboard.

Table A2. Plastic type content of P determined by sensor-based sorting with near-infrared.

\begin{tabular}{ccc}
\hline Fraction & $\begin{array}{c}\text { Mass } \\
(\mathbf{k g})\end{array}$ & $\begin{array}{c}\text { Mass } \\
(\mathbf{\%})\end{array}$ \\
\hline PE & 44.64 & 36.42 \\
PP & 19.19 & 15.66 \\
PET & 25.34 & 20.67 \\
PS & 7.41 & 6.04 \\
Other & 26 & 21.21 \\
Total & 122.58 & 100 \\
\hline
\end{tabular}




\section{Appendix B. DSC Measurements}

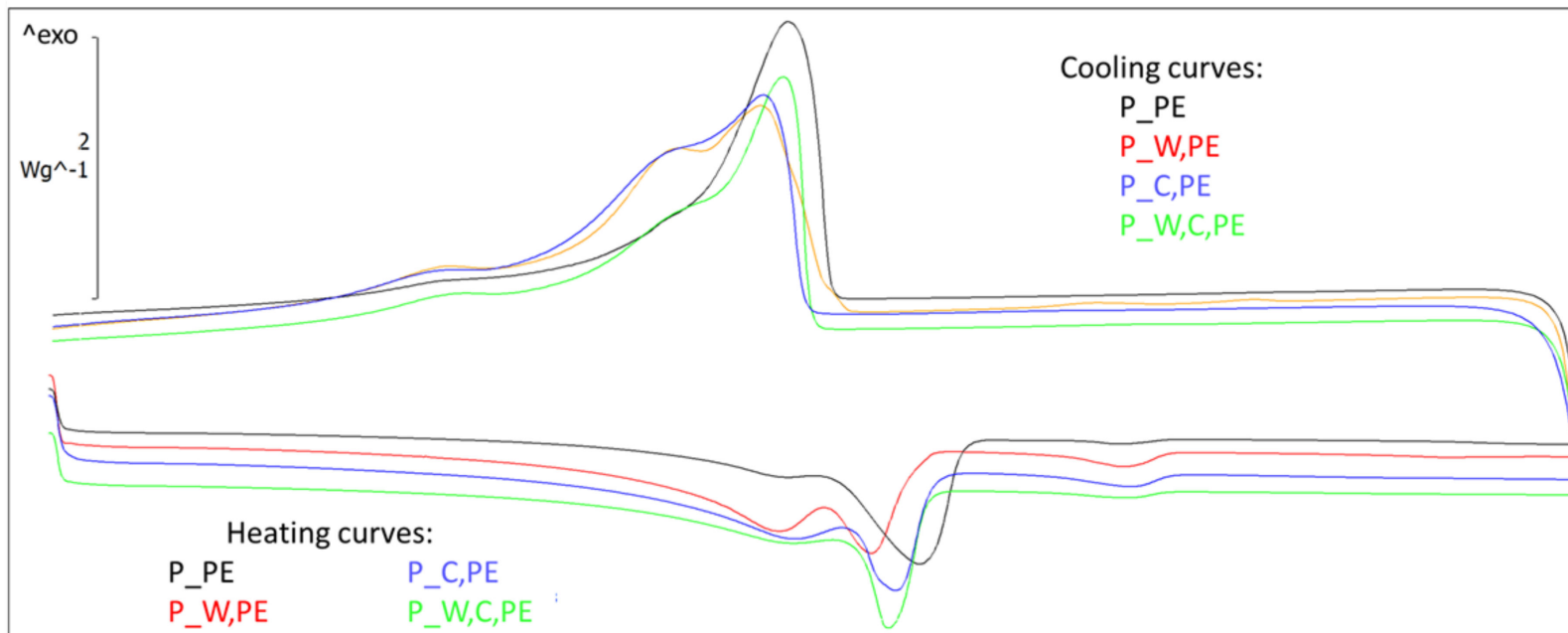

$\begin{array}{llllllllllllllllllllllll}A & 10 & 20 & 30 & 40 & 50 & 60 & 70 & 80 & 90 & 100 & 110 & 120 & 130 & 140 & 150 & 160 & 170 & 180 & 190 & 200 & 210 & 220 & { }^{\circ} \mathrm{C}\end{array}$

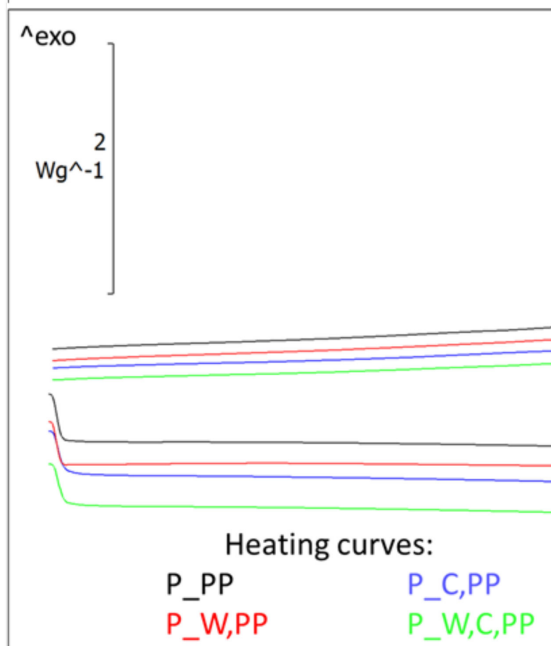

\begin{tabular}{lllllllllllllllllllllllllllll}
$\mathrm{B}$ & 10 & 20 & 30 & 40 & 50 & 60 & 70 & 80 & 90 & 100 & 110 & 120 & 130 & 140 & 150 & 160 & 170 & 180 & 190 & 200 & 210 & ${ }^{\circ} \mathrm{C}$ \\
\hline
\end{tabular}

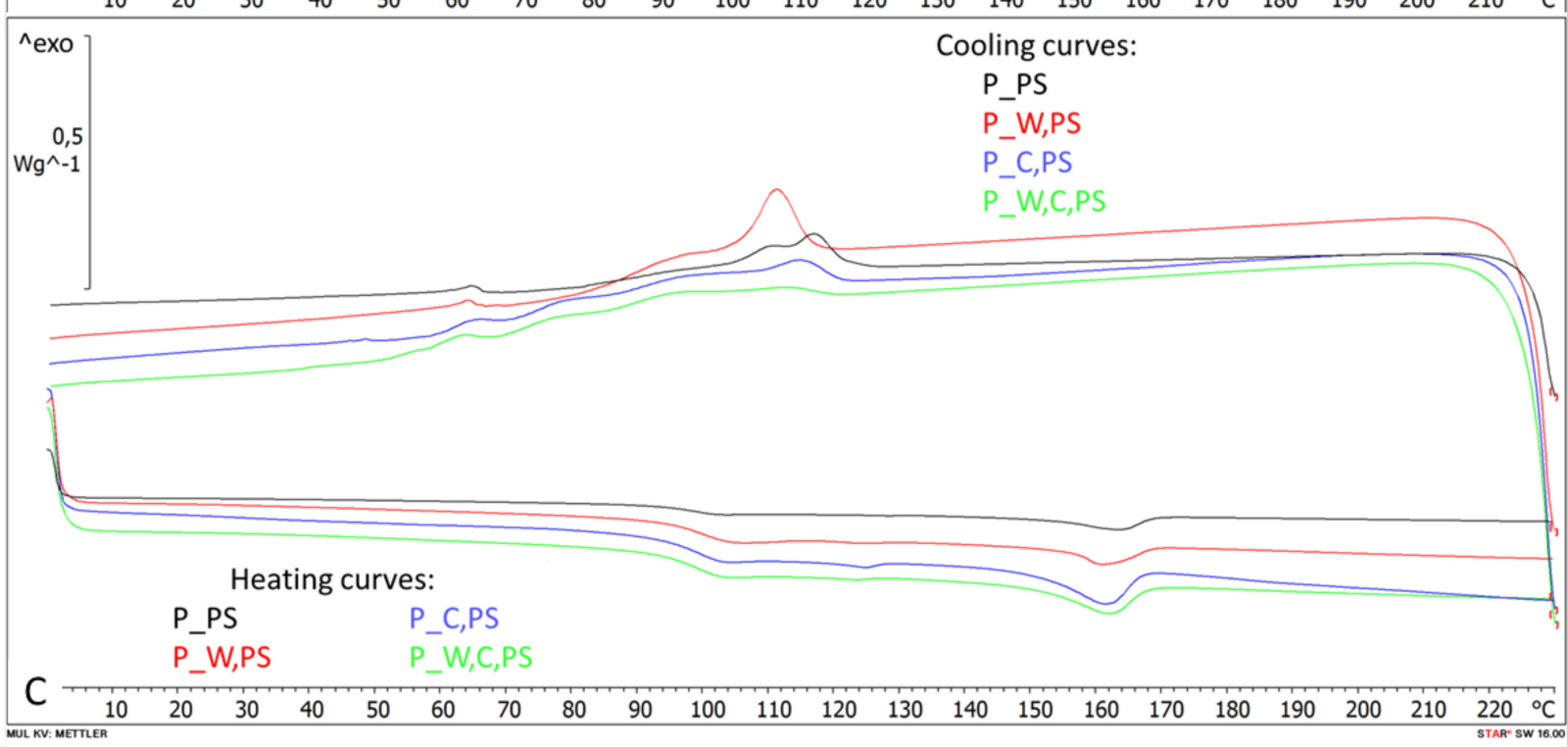

Figure A1. Cont. 


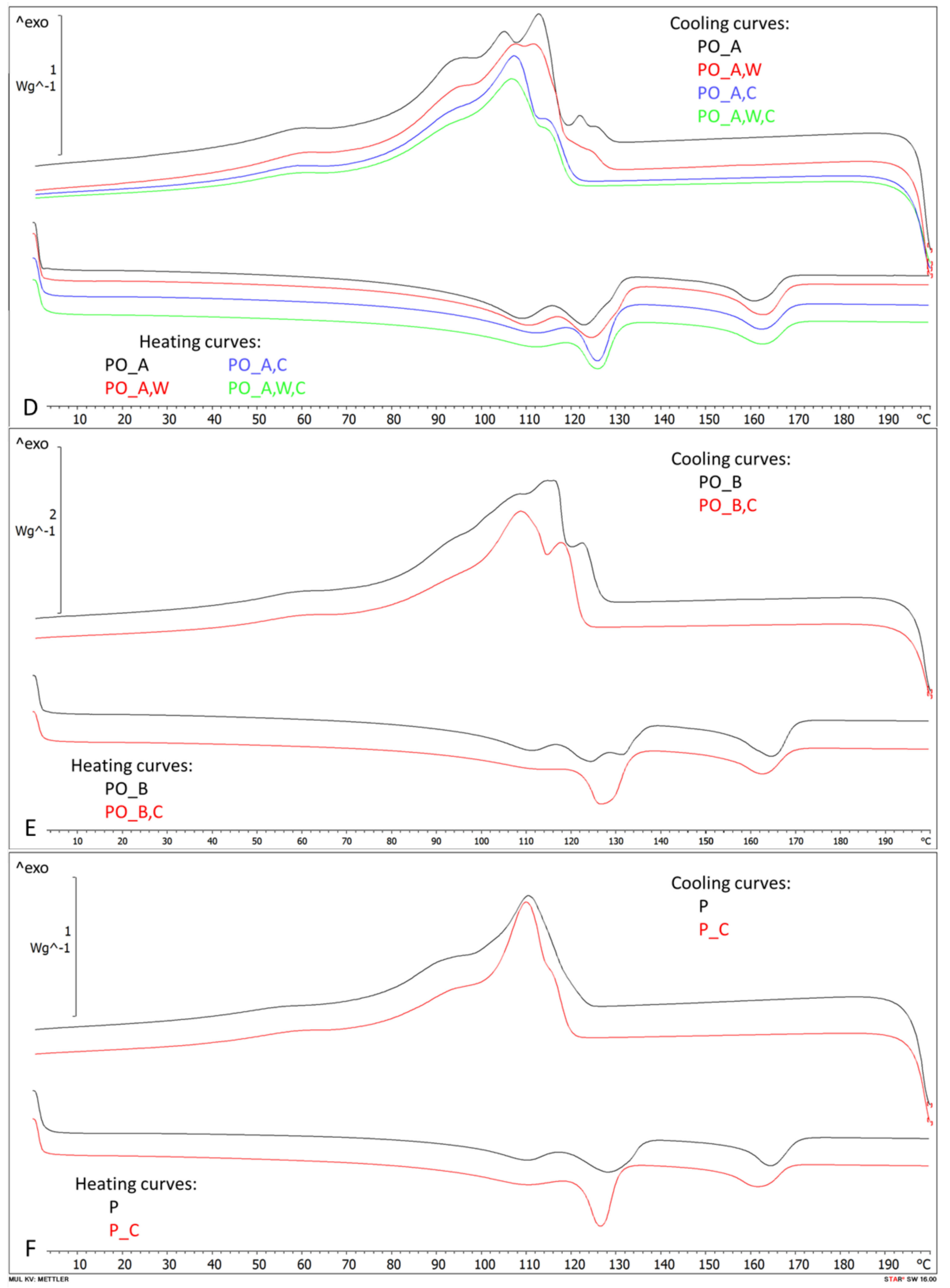

Figure A1. Representative DSC measurement results for (A) PE, (B) PP, (C) PS materials. Note: cooling with $20 \mathrm{~K} / \mathrm{min}$ on top and second heating with $10 \mathrm{~K} / \mathrm{min}$ at the bottom of each diagram, (D) PO_A, (E) PO_B, and (F) P materials. Note: cooling with $20 \mathrm{~K} / \mathrm{min}$ on top and second heating with $10 \mathrm{~K} / \mathrm{min}$ at the bottom of each diagram. 


\section{Appendix C. Processing Conditions}

Table A3. Extrusion conditions for homogenization of all investigated materials.

\begin{tabular}{ccccc}
\hline Materials: & \multicolumn{4}{c}{ P_PE; P_W,PE; P_PP; P_W,PP; P_PS; P_W,PS } \\
\hline Zones & Zone 1 & Zone 2 & Zone 3 & Zone 4 \\
\hline Temperature $\left({ }^{\circ} \mathrm{C}\right)$ & 150 & 170 & 170 & 170 \\
\hline Materials: & & PO_A; PO_A,W; PO_B & \\
\hline Temperature $\left({ }^{\circ} \mathrm{C}\right)$ & Zone 1 & Zone 2 & Zone 3 & Zone 4 \\
\hline
\end{tabular}

Table A4. Compression moulding conditions of all investigated materials.

\begin{tabular}{|c|c|c|c|c|c|}
\hline Materials: & P_PE & P_W,PE & & & \\
\hline Phases & Phase 1 & Phase 2 & Phase 3 & Phase 4 & Phase 5 \\
\hline Temperature $\left({ }^{\circ} \mathrm{C}\right)$ & 210 & 210 & 210 & 210 & 30 \\
\hline Pressure (bar) & 1 & 10 & 50 & 100 & 100 \\
\hline Time (min) & 8 & 5 & 4 & 4 & 15 \\
\hline Materials: & P_C,PE & P_W,C,PE & & & \\
\hline Phases & Phase 1 & Phase 2 & Phase 3 & Phase 4 & Phase 5 \\
\hline Temperature $\left({ }^{\circ} \mathrm{C}\right)$ & 200 & 200 & 200 & 200 & 30 \\
\hline Pressure (bar) & 1 & 10 & 50 & 100 & 100 \\
\hline Time (min) & 10 & 5 & 4 & 4 & 15 \\
\hline Materials: & P_PP & P_W,PP & $P_{-} C, P P$ & P_W,C,PP & \\
\hline Phases & Phase 1 & Phase 2 & Phase 3 & Phase 4 & Phase 5 \\
\hline Temperature $\left({ }^{\circ} \mathrm{C}\right)$ & 200 & 200 & 200 & 200 & 30 \\
\hline Pressure (bar) & 1 & 10 & 50 & 100 & 100 \\
\hline Time (min) & 14 & 5 & 4 & 4 & 15 \\
\hline Materials: & P_PS & P_W,PS & P_C,PS & P_W,C,PS & \\
\hline Phases & Phase 1 & Phase 2 & Phase 3 & Phase 4 & Phase 5 \\
\hline Temperature $\left({ }^{\circ} \mathrm{C}\right)$ & 207 & 205 & 205 & 205 & 30 \\
\hline Pressure (bar) & 5 & 10 & 50 & 100 & 100 \\
\hline Time (min) & 10 & 5 & 4 & 4 & 15 \\
\hline Materials: PO_A & PO_A,W & PO_A,C & PO_A,W,C & PO_B & PO_B,C \\
\hline Phases & Phase 1 & Phase 2 & Phase 3 & Phase 4 & Phase 5 \\
\hline Temperature $\left({ }^{\circ} \mathrm{C}\right)$ & 210 & 210 & 210 & 210 & 30 \\
\hline Pressure (bar) & 1 & 10 & 50 & 100 & 100 \\
\hline Time (min) & 8 & 5 & 4 & 4 & 15 \\
\hline Materials: & $\mathrm{P}$ & P_C & & & \\
\hline Phases & Phase 1 & Phase 2 & Phase 3 & Phase 4 & Phase 5 \\
\hline Temperature $\left({ }^{\circ} \mathrm{C}\right)$ & 210 & 210 & 210 & 210 & 30 \\
\hline Pressure (bar) & 1 & 10 & 50 & 100 & 100 \\
\hline Time (min) & 8 & 5 & 4 & 4 & 15 \\
\hline
\end{tabular}


Appendix D. MFR Measurements

Table A5. MFR measurement results.

\begin{tabular}{|c|c|c|c|c|c|c|}
\hline $\begin{array}{c}\text { Sample } \\
\text { Identification }\end{array}$ & $\begin{array}{l}\text { Sample } \\
\text { Number }\end{array}$ & $\begin{array}{c}\text { Total Mass } \\
\text { (g) }\end{array}$ & $\begin{array}{c}\text { Time Interval } \\
\text { (min) }\end{array}$ & $\begin{array}{c}\text { MFR } \\
\text { (g/10 min) }\end{array}$ & $\begin{array}{l}\text { Mean Value } \\
\text { (g/10 min) }\end{array}$ & $\begin{array}{l}\text { Standard Deviation } \\
\text { (g/10 } \mathrm{min})\end{array}$ \\
\hline P_PE & $\mathrm{P} 1$ & 2.10 & 10 & 2.571 & \multirow{2}{*}{2.479} & \multirow{2}{*}{0.130} \\
\hline P_PE & P2 & 2.09 & 10 & 2.387 & & \\
\hline P_W,PE & P1 & 2.71 & 10 & 2.586 & \multirow{2}{*}{2.641} & \multirow{2}{*}{0.078} \\
\hline P_W,PE & $\mathrm{P} 2$ & 3.08 & 10 & 2.696 & & \\
\hline P_C,PE & P1 & 2.38 & 10 & 2.184 & \multirow{2}{*}{2.147} & \multirow{2}{*}{0.053} \\
\hline P_C,PE & P2 & 2.31 & 15 & 2.110 & & \\
\hline P_W,C,PE & P1 & 2.41 & 20 & 1.794 & \multirow{2}{*}{1.820} & \multirow{2}{*}{0.037} \\
\hline P_W,C,PE & P2 & 2.40 & 20 & 1.846 & & \\
\hline P_PP & $\mathrm{P} 1$ & 2.20 & 5 & 1.805 & \multirow{2}{*}{1.304} & \multirow{2}{*}{0.708} \\
\hline P_PP & P2 & 2.18 & 10 & 0.803 & & \\
\hline P_W,PP & P1 & 2.78 & 10 & 11.801 & \multirow{2}{*}{12.286} & \multirow{2}{*}{0.687} \\
\hline P_W,PP & P2 & 3.35 & 5 & 12.772 & & \\
\hline P_C,PP & P1 & 2.53 & 10 & 3.932 & \multirow{2}{*}{4.178} & \multirow{2}{*}{0.130} \\
\hline P_C,PP & P2 & 2.62 & 10 & 4.029 & & \\
\hline P_W,C,PP & P1 & 2.31 & 10 & 7.114 & \multirow{2}{*}{7.273} & \multirow{2}{*}{0.225} \\
\hline P_W,C,PP & P2 & 3.19 & 10 & 7.432 & & \\
\hline P_PS & $\mathrm{P} 1$ & 2.82 & 20 & 0.218 & \multirow{2}{*}{0.927} & \multirow{2}{*}{1.003} \\
\hline P_PS & $\mathrm{P} 2$ & 2.56 & 10 & 1.636 & & \\
\hline P_W,PS & $\mathrm{P} 1$ & 3.21 & 20 & 1.744 & \multirow{2}{*}{1.217} & \multirow{2}{*}{0.746} \\
\hline P_W,PS & P2 & 2.94 & 20 & 0.689 & & \\
\hline P_C,PS & P1 & 2.00 & 10 & 5.673 & \multirow{2}{*}{5.026} & \multirow{2}{*}{0.914} \\
\hline P_C,PS & $\mathrm{P} 2$ & 2.00 & 10 & 4.380 & & \\
\hline P_W,C,PS & $\mathrm{P} 1$ & 2.78 & 10 & 3.526 & \multirow{2}{*}{2.891} & \multirow{2}{*}{0.898} \\
\hline P_W,C,PS & $\mathrm{P} 2$ & 2.73 & 10 & 2.255 & & \\
\hline PO_A & $\mathrm{P} 1$ & 2.67 & 20 & 0.936 & \multirow{2}{*}{0.920} & 0023 \\
\hline PO_A & $\mathrm{P} 2$ & 2.72 & 20 & 0.904 & & \\
\hline PO_A,W & $\mathrm{P} 1$ & 2.56 & 20 & 0.410 & 0855 & 0630 \\
\hline PO_A,W & P2 & 2.50 & 20 & 1.301 & 0.035 & 0.030 \\
\hline PO_A,C & P1 & 2.23 & 20 & 1.934 & 2042 & 0153 \\
\hline PO_A,C & P2 & 2.56 & 20 & 2.150 & 2.042 & 0.153 \\
\hline PO_A,W,C & P1 & 2.34 & 15 & 2.220 & 2280 & 0085 \\
\hline PO_A,W,C & $\mathrm{P} 2$ & 2.71 & 15 & 2.341 & 2.200 & 0.000 \\
\hline PO_B & P1 & 2.40 & 10 & 3.012 & 3338 & 0460 \\
\hline PO_B & $\mathrm{P} 2$ & 2.44 & 10 & 3.663 & & \\
\hline PO_B,C & P1 & 2.64 & 10 & 2.690 & 2700 & 0013 \\
\hline PO_B,C & P2 & 2.39 & 10 & 2.709 & 2.700 & 0.010 \\
\hline $\mathrm{P}$ & P1 & 2.32 & 10 & 2.798 & 2310 & 0677 \\
\hline $\mathrm{P}$ & $\mathrm{P} 2$ & 2.94 & 10 & 1.840 & 2.319 & $0.07 /$ \\
\hline$P_{-} C$ & P1 & 2.35 & 10 & 3.333 & 3676 & 0485 \\
\hline P_C & P2 & 2.50 & 10 & 4.019 & 0.070 & 0.400 \\
\hline
\end{tabular}




\section{Appendix E. Impact Tests}

Table A6. Results of the notched impact tests and unnotched impact tests of P_PE.

\begin{tabular}{|c|c|c|c|c|c|c|c|c|c|}
\hline $\begin{array}{l}\text { Sample } \\
\text { Number }\end{array}$ & $\begin{array}{c}1 \\
(\mathrm{~mm})\end{array}$ & $\begin{array}{c}b_{B} \\
(\mathrm{~mm})\end{array}$ & $\underset{(\mathrm{mm})}{\mathrm{d}}$ & $\begin{array}{c}A \\
\left(m^{2}\right)\end{array}$ & $\begin{array}{l}W \\
(J)\end{array}$ & $\begin{array}{c}W_{\text {empty }} \\
\text { (J) }\end{array}$ & $\begin{array}{c}W_{\text {corr }} \\
(\mathrm{kJ})\end{array}$ & $\begin{array}{c}\mathrm{a}_{\mathrm{cN}} \\
\left(\mathrm{kJ} / \mathrm{m}^{2}\right)\end{array}$ & Note \\
\hline P1 & 78.54 & 10.10 & 3.51 & 0.000035 & 0.988 & 0.004 & 0.000984 & 27.8 & partially broken \\
\hline P2 & 78.35 & 10.09 & 3.40 & 0.000034 & 0.500 & 0.004 & 0.000496 & 14.5 & partially broken \\
\hline P3 & 78.50 & 10.07 & 3.42 & 0.000034 & 0.596 & 0.004 & 0.000592 & 17.2 & partially broken \\
\hline P4 & 78.62 & 10.09 & 3.42 & 0.000035 & 0.452 & 0.004 & 0.000448 & 13.0 & \\
\hline P5 & 78.26 & 10.08 & 3.48 & 0.000035 & 0.660 & 0.004 & 0.000656 & 18.7 & \\
\hline P6 & 78.62 & 8.12 & 3.51 & 0.000029 & 0.322 & 0.007 & 0.000315 & 11.1 & \\
\hline P7 & 78.64 & 8.15 & 3.51 & 0.000029 & 0.298 & 0.007 & 0.000291 & 10.2 & \\
\hline P8 & 78.72 & 7.89 & 3.48 & 0.000027 & 0.357 & 0.007 & 0.000350 & 12.7 & \\
\hline P9 & 78.55 & 8.00 & 3.53 & 0.000028 & 0.324 & 0.007 & 0.000317 & 11.2 & \\
\hline P10 & 78.71 & 7.95 & 3.49 & 0.000028 & 0.255 & 0.007 & 0.000248 & 8.9 & \\
\hline
\end{tabular}

Table A7. Results of the notched impact tests and unnotched impact tests of P_W,PE.

\begin{tabular}{|c|c|c|c|c|c|c|c|c|c|}
\hline $\begin{array}{l}\text { Sample } \\
\text { Number }\end{array}$ & $\begin{array}{c}1 \\
(\mathrm{~mm})\end{array}$ & $\begin{array}{c}b_{B} \\
(\mathrm{~mm})\end{array}$ & $\begin{array}{c}\mathrm{d} \\
(\mathrm{mm})\end{array}$ & $\underset{\left(\mathrm{m}^{2}\right)}{\mathrm{A}}$ & $\begin{array}{l}W \\
(J)\end{array}$ & $\begin{array}{c}W_{\text {empty }} \\
\text { (J) }\end{array}$ & $\begin{array}{c}W_{\text {corr }} \\
(\mathrm{kJ})\end{array}$ & $\begin{array}{c}\mathrm{a}_{\mathrm{cN}} \\
\left(\mathrm{kJ} / \mathrm{m}^{2}\right)\end{array}$ & Note \\
\hline P1 & 78.94 & 10.08 & 3.50 & 0.000035 & 0.808 & 0.004 & 0.000804 & 22.8 & partially broken \\
\hline $\mathrm{P} 2$ & 79.04 & 10.04 & 3.52 & 0.000035 & 0.732 & 0.004 & 0.000728 & 20.6 & partially broken \\
\hline P3 & 79.03 & 9.95 & 3.49 & 0.000035 & 0.604 & 0.004 & 0.000600 & 17.3 & partially broken \\
\hline $\mathrm{P} 4$ & 78.58 & 10.03 & 3.51 & 0.000035 & 0.844 & 0.004 & 0.000840 & 23.9 & partially broken \\
\hline P5 & 79.10 & 10.15 & 3.51 & 0.000036 & 0.772 & 0.004 & 0.000768 & 21.6 & partially broken \\
\hline P6 & 77.55 & 7.90 & 3.70 & 0.000029 & 0.348 & 0.007 & 0.000341 & 11.7 & \\
\hline P7 & 78.45 & 7.94 & 3.53 & 0.000028 & 0.337 & 0.007 & 0.000330 & 11.8 & \\
\hline P8 & 78.46 & 7.84 & 3.54 & 0.000028 & 0.345 & 0.007 & 0.000338 & 12.2 & partially broken \\
\hline P9 & 78.30 & 8.03 & 3.49 & 0.000028 & 0.348 & 0.007 & 0.000341 & 12.2 & \\
\hline P10 & 77.60 & 7.79 & 3.60 & 0.000028 & 0.364 & 0.007 & 0.000357 & 12.7 & partially broken \\
\hline
\end{tabular}

Table A8. Results of the notched impact tests and unnotched impact tests of P_C,PE.

\begin{tabular}{|c|c|c|c|c|c|c|c|c|c|}
\hline $\begin{array}{l}\text { Scheme } \\
\text { Number }\end{array}$ & $\begin{array}{c}1 \\
(\mathrm{~mm})\end{array}$ & $\begin{array}{c}b_{B} \\
(\mathbf{m m})\end{array}$ & $\underset{(\mathrm{mm})}{\mathrm{d}}$ & $\underset{\left(\mathrm{m}^{2}\right)}{\mathrm{A}}$ & $\begin{array}{l}W \\
\text { (J) }\end{array}$ & $\begin{array}{c}W_{\text {empty }} \\
\text { (J) }\end{array}$ & $\begin{array}{c}\mathbf{W}_{\text {corr }} \\
(\mathrm{kJ})\end{array}$ & $\begin{array}{c}\mathrm{a}_{\mathrm{cN}} \\
\left(\mathrm{kJ} / \mathrm{m}^{2}\right)\end{array}$ & Note \\
\hline P1 & 79.17 & 10.14 & 3.69 & 0.000037 & 0.764 & 0.004 & 0.000760 & 20.3 & \\
\hline $\mathrm{P} 2$ & 79.06 & 10.15 & 3.72 & 0.000038 & 1.068 & 0.004 & 0.001064 & 28.2 & \\
\hline P3 & 79.17 & 10.18 & 3.75 & 0.000038 & 0.604 & 0.004 & 0.000600 & 15.7 & \\
\hline $\mathrm{P} 4$ & 79.03 & 10.17 & 3.65 & 0.000037 & 0.716 & 0.004 & 0.000712 & 19.2 & \\
\hline P5 & 78.08 & 10.14 & 3.64 & 0.000037 & 1.240 & 0.004 & 0.001236 & 33.5 & \\
\hline P6 & 78.13 & 7.96 & 3.58 & 0.000028 & 0.213 & 0.007 & 0.000206 & 7.2 & \\
\hline P7 & 78.04 & 7.95 & 3.55 & 0.000028 & 0.213 & 0.007 & 0.000206 & 7.3 & \\
\hline P8 & 78.03 & 8.01 & 3.56 & 0.000029 & 0.230 & 0.007 & 0.000223 & 7.8 & \\
\hline P9 & 78.10 & 8.00 & 3.68 & 0.000029 & 0.206 & 0.007 & 0.000199 & 6.8 & \\
\hline P10 & 78.10 & 8.01 & 3.61 & 0.000029 & 0.214 & 0.007 & 0.000207 & 7.2 & \\
\hline
\end{tabular}


Table A9. Results of the notched impact tests and unnotched impact tests of P_W,C,PE.

\begin{tabular}{|c|c|c|c|c|c|c|c|c|c|}
\hline $\begin{array}{l}\text { Sample } \\
\text { Number }\end{array}$ & $\begin{array}{c}1 \\
(\mathrm{~mm})\end{array}$ & $\begin{array}{c}b_{B} \\
(\mathrm{~mm})\end{array}$ & $\begin{array}{c}\mathrm{d} \\
(\mathrm{mm})\end{array}$ & $\begin{array}{c}\text { A } \\
\left(\mathrm{m}^{2}\right)\end{array}$ & $\begin{array}{l}W \\
\text { (J) }\end{array}$ & $\begin{array}{c}W_{\text {empty }} \\
\text { (J) }\end{array}$ & $\begin{array}{c}W_{\text {corr }} \\
(\mathrm{kJ})\end{array}$ & $\underset{\left(\mathrm{kJ} / \mathrm{m}^{2}\right)}{\mathrm{a}_{\mathrm{cN}}}$ & Note \\
\hline P1 & 78.52 & 10.18 & 3.59 & 0.000037 & 2.080 & 0.030 & 0.002050 & 56.1 & not broken \\
\hline $\mathrm{P} 2$ & 78.18 & 10.16 & 3.54 & 0.000036 & 1.260 & 0.030 & 0.001230 & 34.2 & not broken \\
\hline P3 & 78.37 & 10.19 & 3.53 & 0.000036 & 3.250 & 0.030 & 0.003220 & 89.5 & not broken \\
\hline $\mathrm{P} 4$ & 78.25 & 10.22 & 3.55 & 0.000036 & 2.770 & 0.030 & 0.002740 & 75.5 & not broken \\
\hline P5 & 78.49 & 10.15 & 3.53 & 0.000036 & 3.000 & 0.030 & 0.002970 & 82.9 & not broken \\
\hline P6 & 78.67 & 8.00 & 3.57 & 0.000029 & 0.270 & 0.007 & 0.000263 & 9.2 & \\
\hline P7 & 78.72 & 7.90 & 3.58 & 0.000028 & 0.251 & 0.007 & 0.000244 & 8.6 & \\
\hline P8 & 78.77 & 7.82 & 3.56 & 0.000028 & 0.255 & 0.007 & 0.000248 & 8.9 & \\
\hline P9 & 78.74 & 8.05 & 3.60 & 0.000029 & 0.267 & 0.007 & 0.000260 & 9.0 & \\
\hline P10 & 78.79 & 8.06 & 3.59 & 0.000029 & 0.252 & 0.007 & 0.000245 & 8.5 & \\
\hline
\end{tabular}

Table A10. Results of the notched impact tests and unnotched impact tests of P_PP.

\begin{tabular}{|c|c|c|c|c|c|c|c|c|c|}
\hline $\begin{array}{l}\text { Sample } \\
\text { Number }\end{array}$ & $\begin{array}{c}1 \\
(\mathrm{~mm})\end{array}$ & $\begin{array}{c}b_{B} \\
(\mathrm{~mm})\end{array}$ & $\begin{array}{c}\mathrm{d} \\
(\mathrm{mm})\end{array}$ & $\begin{array}{c}A \\
\left(m^{2}\right)\end{array}$ & $\begin{array}{l}W \\
\text { (J) }\end{array}$ & $\begin{array}{c}W_{\text {empty }} \\
\text { (J) }\end{array}$ & $\begin{array}{c}\mathbf{W}_{\text {corr }} \\
(\mathbf{k J})\end{array}$ & $\begin{array}{c}a_{\mathrm{cN}} \\
\left(\mathrm{kJ} / \mathrm{m}^{2}\right)\end{array}$ & Note \\
\hline P1 & 78.60 & 10.24 & 3.81 & 0.000039 & 0.188 & 0.008 & 0.000180 & 4.6 & \\
\hline P2 & 77.92 & 10.25 & 3.62 & 0.000037 & 0.258 & 0.008 & 0.000250 & 6.7 & \\
\hline P3 & 77.94 & 10.25 & 3.62 & 0.000037 & 0.126 & 0.008 & 0.000118 & 3.2 & \\
\hline P4 & 77.92 & 10.25 & 3.63 & 0.000037 & 0.152 & 0.008 & 0.000144 & 3.9 & \\
\hline P5 & 77.91 & 10.25 & 3.62 & 0.000037 & 0.213 & 0.008 & 0.000205 & 5.5 & \\
\hline P6 & 78.80 & 8.37 & 3.59 & 0.000030 & 0.084 & 0.007 & 0.000077 & 2.6 & \\
\hline P7 & 79.26 & 8.29 & 3.63 & 0.000030 & 0.073 & 0.007 & 0.000066 & 2.2 & \\
\hline P8 & 78.20 & 8.20 & 3.60 & 0.000030 & 0.097 & 0.007 & 0.000090 & 3.0 & \\
\hline P9 & 78.06 & 8.13 & 3.63 & 0.000030 & 0.095 & 0.007 & 0.000088 & 3.0 & \\
\hline P10 & 77.68 & 8.57 & 3.67 & 0.000031 & 0.069 & 0.007 & 0.000062 & 2.0 & \\
\hline
\end{tabular}

Table A11. Results of the notched impact tests and unnotched impact tests of P_W,PP.

\begin{tabular}{|c|c|c|c|c|c|c|c|c|c|}
\hline $\begin{array}{l}\text { Sample } \\
\text { Number }\end{array}$ & $\begin{array}{c}1 \\
(\mathrm{~mm})\end{array}$ & $\begin{array}{c}b_{B} \\
(\mathrm{~mm})\end{array}$ & $\begin{array}{c}\mathrm{d} \\
(\mathrm{mm})\end{array}$ & $\underset{\left(\mathrm{m}^{2}\right)}{\mathrm{A}}$ & $\begin{array}{l}W \\
\text { (J) }\end{array}$ & $\begin{array}{c}W_{\text {empty }} \\
\text { (J) }\end{array}$ & $\begin{array}{c}\mathrm{W}_{\text {corr }} \\
(\mathrm{kJ})\end{array}$ & $\underset{\left(\mathrm{kJ} / \mathrm{m}^{2}\right)}{\mathrm{a}_{\mathrm{cN}}}$ & Note \\
\hline P1 & 77.24 & 10.25 & 3.65 & 0.000037 & 0.220 & 0.004 & 0.000216 & 5.8 & \\
\hline P2 & 77.65 & 10.30 & 3.60 & 0.000037 & 0.180 & 0.004 & 0.000176 & 4.7 & \\
\hline P3 & 77.40 & 10.24 & 3.58 & 0.000037 & 0.312 & 0.004 & 0.000308 & 8.4 & \\
\hline P4 & 77.88 & 10.18 & 3.60 & 0.000037 & 0.216 & 0.004 & 0.000212 & 5.8 & \\
\hline P5 & 77.59 & 10.20 & 3.55 & 0.000036 & 0.264 & 0.004 & 0.000260 & 7.2 & \\
\hline P6 & 79.02 & 7.96 & 3.65 & 0.000029 & 0.068 & 0.007 & 0.000061 & 2.1 & \\
\hline P7 & 77.68 & 7.96 & 3.80 & 0.000030 & 0.064 & 0.007 & 0.000057 & 1.9 & \\
\hline P8 & 77.86 & 8.38 & 3.76 & 0.000032 & 0.106 & 0.007 & 0.000099 & 3.1 & \\
\hline P9 & 77.92 & 8.01 & 3.77 & 0.000030 & 0.072 & 0.007 & 0.000065 & 2.2 & \\
\hline P10 & 79.02 & 8.22 & 3.80 & 0.000031 & 0.096 & 0.007 & 0.000089 & 2.8 & \\
\hline
\end{tabular}


Table A12. Results of the notched impact tests and unnotched impact tests of P_C,PP.

\begin{tabular}{|c|c|c|c|c|c|c|c|c|c|}
\hline $\begin{array}{l}\text { Sample } \\
\text { Number }\end{array}$ & $\begin{array}{c}1 \\
(\mathrm{~mm})\end{array}$ & $\begin{array}{c}b_{B} \\
(\mathrm{~mm})\end{array}$ & $\begin{array}{c}\mathrm{d} \\
(\mathrm{mm})\end{array}$ & $\underset{\left(\mathrm{m}^{2}\right)}{\mathrm{A}}$ & $\begin{array}{l}W \\
(J)\end{array}$ & $\begin{array}{c}W_{\text {empty }} \\
\text { (J) }\end{array}$ & $\begin{array}{c}\mathrm{W}_{\text {corr }} \\
(\mathrm{kJ})\end{array}$ & $\frac{\mathrm{a}_{\mathrm{cN}}}{\left(\mathrm{kJ} / \mathrm{m}^{2}\right)}$ & Note \\
\hline P1 & 77.61 & 10.35 & 3.88 & 0.000040 & 0.197 & 0.008 & 0.000189 & 4.7 & \\
\hline P2 & 78.07 & 10.25 & 3.70 & 0.000038 & 0.221 & 0.008 & 0.000213 & 5.6 & \\
\hline P3 & 77.84 & 10.10 & 3.70 & 0.000037 & 0.357 & 0.008 & 0.000349 & 9.3 & \\
\hline P4 & 78.05 & 10.22 & 3.73 & 0.000038 & 0.363 & 0.008 & 0.000355 & 9.3 & \\
\hline P5 & 77.47 & 10.02 & 3.69 & 0.000037 & 0.382 & 0.008 & 0.000374 & 10.1 & \\
\hline P6 & 77.77 & 8.06 & 3.68 & 0.000030 & 0.121 & 0.007 & 0.000114 & 3.8 & \\
\hline P7 & 78.08 & 8.24 & 3.64 & 0.000030 & 0.116 & 0.007 & 0.000109 & 3.6 & \\
\hline P8 & 77.89 & 8.37 & 3.66 & 0.000031 & 0.106 & 0.007 & 0.000099 & 3.2 & \\
\hline P9 & 77.85 & 8.14 & 3.69 & 0.000030 & 0.108 & 0.007 & 0.000101 & 3.4 & \\
\hline P10 & 77.94 & 8.43 & 3.92 & 0.000033 & 0.119 & 0.007 & 0.000112 & 3.4 & \\
\hline
\end{tabular}

Table A13. Results of the notched impact tests and unnotched impact tests of P_W,C,PP.

\begin{tabular}{|c|c|c|c|c|c|c|c|c|c|}
\hline $\begin{array}{l}\text { Sample } \\
\text { Number }\end{array}$ & $\begin{array}{c}1 \\
(\mathrm{~mm})\end{array}$ & $\begin{array}{c}b_{B} \\
(\mathrm{~mm})\end{array}$ & $\begin{array}{c}\mathrm{d} \\
(\mathrm{mm})\end{array}$ & $\underset{\left(\mathrm{m}^{2}\right)}{\mathrm{A}}$ & $\begin{array}{l}W \\
(J)\end{array}$ & $\begin{array}{c}W_{\text {empty }} \\
\text { (J) }\end{array}$ & $\begin{array}{c}\mathbf{W}_{\text {corr }} \\
(\mathrm{kJ})\end{array}$ & $\underset{\left(\mathrm{kJ} / \mathrm{m}^{2}\right)}{\mathrm{a}_{\mathrm{cN}}}$ & Note \\
\hline P1 & 77.87 & 10.25 & 3.70 & 0.000038 & 0.948 & 0.004 & 0.000944 & 24.9 & \\
\hline P2 & 77.85 & 10.20 & 3.71 & 0.000038 & 0.464 & 0.004 & 0.000460 & 12.2 & \\
\hline P3 & 77.49 & 10.25 & 3.80 & 0.000039 & 0.508 & 0.004 & 0.000504 & 12.9 & \\
\hline P4 & 77.50 & 10.25 & 3.63 & 0.000037 & 0.244 & 0.004 & 0.000240 & 6.5 & \\
\hline P5 & 77.47 & 10.00 & 3.65 & 0.000037 & 0.412 & 0.004 & 0.000408 & 11.2 & \\
\hline P6 & 77.74 & 8.14 & 3.65 & 0.000030 & 0.131 & 0.007 & 0.000124 & 4.2 & \\
\hline P7 & 77.68 & 8.02 & 3.65 & 0.000029 & 0.133 & 0.007 & 0.000126 & 4.3 & \\
\hline P8 & 77.74 & 8.22 & 3.65 & 0.000030 & 0.113 & 0.007 & 0.000106 & 3.5 & \\
\hline P9 & 77.78 & 7.99 & 3.67 & 0.000029 & 0.139 & 0.007 & 0.000132 & 4.5 & \\
\hline P10 & 77.63 & 8.28 & 3.61 & 0.000030 & 0.147 & 0.007 & 0.000140 & 4.7 & \\
\hline
\end{tabular}

Table A14. Results of the notched impact tests and unnotched impact tests of P_PS.

\begin{tabular}{|c|c|c|c|c|c|c|c|c|c|}
\hline $\begin{array}{l}\text { Sample } \\
\text { Number }\end{array}$ & $\begin{array}{c}1 \\
(\mathrm{~mm})\end{array}$ & $\begin{array}{c}b_{B} \\
(\mathrm{~mm})\end{array}$ & $\begin{array}{c}\mathrm{d} \\
(\mathrm{mm})\end{array}$ & $\begin{array}{c}\mathrm{A} \\
\left(\mathrm{m}^{2}\right)\end{array}$ & $\begin{array}{l}W \\
(J)\end{array}$ & $\begin{array}{c}W_{\text {empty }} \\
\text { (J) }\end{array}$ & $\begin{array}{c}\mathrm{W}_{\text {corr }} \\
(\mathrm{kJ})\end{array}$ & $\begin{array}{c}a_{\mathrm{cN}} \\
\left(\mathrm{kJ} / \mathrm{m}^{2}\right)\end{array}$ & Note \\
\hline P1 & 79.32 & 10.30 & 3.88 & 0.000040 & 0.121 & 0.006 & 0.000115 & 2.9 & \\
\hline $\mathrm{P} 2$ & 79.54 & 10.30 & 3.86 & 0.000040 & 0.098 & 0.006 & 0.000092 & 2.3 & \\
\hline P3 & 79.24 & 10.30 & 3.85 & 0.000040 & 0.129 & 0.006 & 0.000123 & 3.1 & \\
\hline $\mathrm{P} 4$ & 79.75 & 10.30 & 3.91 & 0.000040 & 0.143 & 0.006 & 0.000137 & 3.4 & \\
\hline P5 & 79.59 & 10.10 & 3.90 & 0.000039 & 0.149 & 0.006 & 0.000143 & 3.6 & \\
\hline P6 & 79.10 & 8.03 & 3.93 & 0.000032 & 0.091 & 0.006 & 0.000085 & 2.7 & \\
\hline P7 & 78.58 & 7.93 & 3.98 & 0.000032 & 0.085 & 0.006 & 0.000079 & 2.5 & \\
\hline P8 & 78.46 & 7.83 & 3.96 & 0.000031 & 0.083 & 0.006 & 0.000077 & 2.5 & \\
\hline P9 & 78.62 & 7.95 & 3.98 & 0.000032 & 0.085 & 0.006 & 0.000079 & 2.5 & \\
\hline P10 & 78.78 & 8.01 & 3.95 & 0.000032 & 0.088 & 0.006 & 0.000082 & 2.6 & \\
\hline
\end{tabular}


Table A15. Results of the notched impact tests and unnotched impact tests of P_W,PS.

\begin{tabular}{|c|c|c|c|c|c|c|c|c|c|}
\hline $\begin{array}{l}\text { Sample } \\
\text { Number }\end{array}$ & $\begin{array}{c}1 \\
(\mathrm{~mm})\end{array}$ & $\begin{array}{c}b_{B} \\
(\mathrm{~mm})\end{array}$ & $\begin{array}{c}\mathrm{d} \\
(\mathrm{mm})\end{array}$ & $\underset{\left(\mathrm{m}^{2}\right)}{\mathrm{A}}$ & $\begin{array}{l}W \\
(J)\end{array}$ & $\begin{array}{c}W_{\text {empty }} \\
\text { (J) }\end{array}$ & $\begin{array}{c}\mathrm{W}_{\text {corr }} \\
(\mathrm{kJ})\end{array}$ & $\begin{array}{c}\mathrm{a}_{\mathrm{cN}} \\
\left(\mathrm{kJ} / \mathrm{m}^{2}\right)\end{array}$ & Note \\
\hline P1 & 79.61 & 10.29 & 3.89 & 0.000040 & 0.101 & 0.008 & 0.000093 & 2.3 & \\
\hline $\mathrm{P} 2$ & 79.39 & 10.18 & 3.88 & 0.000039 & 0.152 & 0.008 & 0.000144 & 3.6 & \\
\hline P3 & 80.18 & 10.21 & 3.85 & 0.000039 & 0.109 & 0.008 & 0.000101 & 2.6 & \\
\hline $\mathrm{P} 4$ & 79.55 & 10.27 & 3.95 & 0.000041 & 0.145 & 0.008 & 0.000137 & 3.4 & \\
\hline P5 & 79.47 & 10.35 & 3.87 & 0.000040 & 0.157 & 0.008 & 0.000149 & 3.7 & \\
\hline P6 & 78.44 & 7.88 & 3.89 & 0.000031 & 0.110 & 0.007 & 0.000103 & 3.4 & \\
\hline P7 & 78.31 & 8.17 & 3.93 & 0.000032 & 0.109 & 0.007 & 0.000102 & 3.2 & \\
\hline P8 & 79.49 & 8.39 & 3.84 & 0.000032 & 0.092 & 0.007 & 0.000085 & 2.6 & \\
\hline P9 & 79.65 & 8.18 & 3.85 & 0.000031 & 0.079 & 0.007 & 0.000072 & 2.3 & \\
\hline P10 & 79.74 & 8.50 & 3.86 & 0.000033 & 0.091 & 0.007 & 0.000084 & 2.6 & \\
\hline
\end{tabular}

Table A16. Results of the notched impact tests and unnotched impact tests of P_C,PS.

\begin{tabular}{|c|c|c|c|c|c|c|c|c|c|}
\hline $\begin{array}{l}\text { Sample } \\
\text { Number }\end{array}$ & $\begin{array}{c}1 \\
(\mathrm{~mm})\end{array}$ & $\begin{array}{c}b_{B} \\
(\mathrm{~mm})\end{array}$ & $\begin{array}{c}\mathrm{d} \\
(\mathrm{mm})\end{array}$ & $\underset{\left(\mathrm{m}^{2}\right)}{\mathrm{A}}$ & $\begin{array}{l}W \\
(J)\end{array}$ & $\begin{array}{c}W_{\text {empty }} \\
\text { (J) }\end{array}$ & $\begin{array}{c}\mathbf{W}_{\text {corr }} \\
(\mathrm{kJ})\end{array}$ & $\underset{\left(\mathrm{kJ} / \mathrm{m}^{2}\right)}{\mathrm{a}_{\mathrm{cN}}}$ & Note \\
\hline P1 & 79.92 & 10.40 & 3.99 & 0.000041 & 0.157 & 0.008 & 0.000149 & 3.6 & \\
\hline P2 & 79.79 & 10.40 & 4.03 & 0.000042 & 0.230 & 0.008 & 0.000222 & 5.3 & \\
\hline P3 & 78.26 & 10.36 & 3.95 & 0.000041 & 0.175 & 0.008 & 0.000167 & 4.1 & \\
\hline P4 & 79.78 & 10.40 & 4.02 & 0.000042 & 0.157 & 0.008 & 0.000149 & 3.6 & \\
\hline P5 & 79.92 & 10.14 & 3.99 & 0.000040 & 0.222 & 0.008 & 0.000214 & 5.3 & \\
\hline P6 & 78.64 & 8.26 & 3.97 & 0.000033 & 0.050 & 0.007 & 0.000043 & 1.3 & \\
\hline P7 & 78.68 & 8.12 & 3.96 & 0.000032 & 0.048 & 0.007 & 0.000041 & 1.3 & \\
\hline P8 & 78.73 & 8.07 & 3.98 & 0.000032 & 0.047 & 0.007 & 0.000040 & 1.2 & \\
\hline P9 & 78.72 & 8.01 & 3.99 & 0.000032 & 0.052 & 0.007 & 0.000045 & 1.4 & \\
\hline P10 & 78.85 & 7.95 & 4.02 & 0.000032 & 0.047 & 0.007 & 0.000040 & 1.3 & \\
\hline
\end{tabular}

Table A17. Results of the notched impact tests and unnotched impact tests of P_W,C,PS.

\begin{tabular}{|c|c|c|c|c|c|c|c|c|c|}
\hline $\begin{array}{l}\text { Sample } \\
\text { Number }\end{array}$ & $\begin{array}{c}1 \\
(\mathrm{~mm})\end{array}$ & $\begin{array}{c}\mathrm{b}_{\mathrm{B}} \\
(\mathrm{mm})\end{array}$ & $\begin{array}{c}\mathrm{d} \\
(\mathrm{mm})\end{array}$ & $\underset{\left(m^{2}\right)}{A}$ & $\begin{array}{l}W \\
(J)\end{array}$ & $\begin{array}{c}\text { Wempty }_{\text {em }} \\
\text { (J) }\end{array}$ & $\begin{array}{c}\mathbf{W}_{\text {corr }} \\
(\mathbf{k J})\end{array}$ & $\begin{array}{c}\mathrm{a}_{\mathrm{cN}} \\
\left(\mathrm{kJ} / \mathrm{m}^{2}\right)\end{array}$ & Note \\
\hline P1 & 79.42 & 10.30 & 4.04 & 0.000042 & 0.155 & 0.008 & 0.000147 & 3.5 & \\
\hline P2 & 79.09 & 10.25 & 4.00 & 0.000041 & 0.114 & 0.008 & 0.000106 & 2.6 & \\
\hline P3 & 79.28 & 10.35 & 3.95 & 0.000041 & 0.163 & 0.008 & 0.000155 & 3.8 & \\
\hline P4 & 79.44 & 10.30 & 3.91 & 0.000040 & 0.179 & 0.008 & 0.000171 & 4.2 & \\
\hline P5 & 79.45 & 10.31 & 3.90 & 0.000040 & 0.217 & 0.008 & 0.000209 & 5.2 & \\
\hline P6 & 79.08 & 8.02 & 3.94 & 0.000032 & 0.067 & 0.007 & 0.000060 & 1.9 & \\
\hline P7 & 79.12 & 8.04 & 3.87 & 0.000031 & 0.055 & 0.007 & 0.000048 & 1.5 & \\
\hline P8 & 79.36 & 8.08 & 3.99 & 0.000032 & 0.054 & 0.007 & 0.000047 & 1.5 & \\
\hline P9 & 79.29 & 7.88 & 3.98 & 0.000031 & 0.049 & 0.007 & 0.000042 & 1.3 & \\
\hline P10 & 79.37 & 8.20 & 3.89 & 0.000032 & 0.055 & 0.007 & 0.000048 & 1.5 & \\
\hline
\end{tabular}


Table A18. Results of the notched impact tests and unnotched impact tests of PO_A.

\begin{tabular}{|c|c|c|c|c|c|c|c|c|c|}
\hline $\begin{array}{l}\text { Sample } \\
\text { Number }\end{array}$ & $\begin{array}{c}1 \\
(\mathrm{~mm})\end{array}$ & $\begin{array}{c}\mathrm{b}_{\mathrm{B}} \\
(\mathrm{mm})\end{array}$ & $\begin{array}{c}\mathrm{d} \\
(\mathrm{mm})\end{array}$ & $\begin{array}{c}\mathrm{A} \\
\left(\mathrm{m}^{2}\right)\end{array}$ & $\begin{array}{l}W \\
(J)\end{array}$ & $\begin{array}{c}W_{\text {empty }} \\
\text { (J) }\end{array}$ & $\begin{array}{c}\mathbf{W}_{\text {corr }} \\
(\mathrm{kJ})\end{array}$ & $\underset{\left(\mathrm{kJ} / \mathrm{m}^{2}\right)}{\mathrm{a}_{\mathrm{cN}}}$ & Note \\
\hline $\mathrm{P} 1$ & 79.36 & 10.03 & 3.76 & 0.000038 & 0.276 & 0.008 & 0.000268 & 7.1 & partially broken \\
\hline $\mathrm{P} 2$ & 79.57 & 10.06 & 3.73 & 0.000038 & 0.245 & 0.008 & 0.000237 & 6.3 & partially broken \\
\hline P3 & 79.46 & 10.13 & 3.76 & 0.000038 & 0.252 & 0.008 & 0.000244 & 6.4 & partially broken \\
\hline $\mathrm{P} 4$ & 79.66 & 10.06 & 3.75 & 0.000038 & 0.242 & 0.008 & 0.000234 & 6.2 & partially broken \\
\hline P5 & 79.38 & 10.03 & 3.80 & 0.000038 & 0.247 & 0.008 & 0.000239 & 6.3 & partially broken \\
\hline P6 & 78.64 & 8.13 & 3.79 & 0.000031 & 0.200 & 0.007 & 0.000193 & 6.3 & \\
\hline P7 & 78.57 & 8.00 & 3.80 & 0.000030 & 0.203 & 0.007 & 0.000196 & 6.4 & partially broken \\
\hline P8 & 78.63 & 8.08 & 3.78 & 0.000031 & 0.159 & 0.007 & 0.000152 & 5.0 & \\
\hline P9 & 78.61 & 8.15 & 3.83 & 0.000031 & 0.193 & 0.007 & 0.000186 & 6.0 & partially broken \\
\hline P10 & 78.59 & 8.13 & 3.78 & 0.000031 & 0.215 & 0.007 & 0.000208 & 6.8 & \\
\hline
\end{tabular}

Table A19. Results of the notched impact tests and unnotched impact tests of PO_A,W.

\begin{tabular}{|c|c|c|c|c|c|c|c|c|c|}
\hline $\begin{array}{l}\text { Sample } \\
\text { Number }\end{array}$ & $\begin{array}{c}1 \\
(\mathrm{~mm})\end{array}$ & $\begin{array}{c}b_{B} \\
(\mathrm{~mm})\end{array}$ & $\underset{(\mathrm{mm})}{\mathrm{d}}$ & $\underset{\left(\mathrm{m}^{2}\right)}{\mathrm{A}}$ & $\begin{array}{l}W \\
(J)\end{array}$ & $\begin{array}{c}W_{\text {empty }} \\
\text { (J) }\end{array}$ & $\begin{array}{c}W_{\text {corr }} \\
\text { (kJ) }\end{array}$ & $\begin{array}{c}a_{\mathrm{cN}} \\
\left(\mathrm{kJ} / \mathrm{m}^{2}\right)\end{array}$ & Note \\
\hline $\mathrm{P} 1$ & 78.52 & 10.11 & 3.68 & 0.000037 & 0.316 & 0.004 & 0.000312 & 8.4 & \\
\hline P2 & 78.98 & 10.11 & 3.82 & 0.000039 & 0.388 & 0.004 & 0.000384 & 9.9 & partially broken \\
\hline P3 & 78.64 & 10.10 & 3.70 & 0.000037 & 0.308 & 0.004 & 0.000304 & 8.1 & partially broken \\
\hline $\mathrm{P} 4$ & 78.66 & 10.20 & 3.68 & 0.000038 & 0.396 & 0.004 & 0.000392 & 10.4 & partially broken \\
\hline P5 & 78.70 & 10.15 & 3.65 & 0.000037 & 0.396 & 0.004 & 0.000392 & 10.6 & partially broken \\
\hline P6 & 78.85 & 8.01 & 3.67 & 0.000029 & 0.234 & 0.007 & 0.000227 & 7.7 & \\
\hline P7 & 78.86 & 8.30 & 3.61 & 0.000030 & 0.219 & 0.007 & 0.000212 & 7.1 & \\
\hline P8 & 78.85 & 8.13 & 3.62 & 0.000029 & 0.191 & 0.007 & 0.000184 & 6.3 & \\
\hline P9 & 78.75 & 8.15 & 3.65 & 0.000030 & 0.217 & 0.007 & 0.000210 & 7.1 & \\
\hline P10 & 78.70 & 8.09 & 3.64 & 0.000029 & 0.200 & 0.007 & 0.000193 & 6.6 & \\
\hline
\end{tabular}

Table A20. Results of the notched impact tests and unnotched impact tests of PO_A,C.

\begin{tabular}{|c|c|c|c|c|c|c|c|c|c|}
\hline $\begin{array}{l}\text { Sample } \\
\text { Number }\end{array}$ & $\begin{array}{c}1 \\
(\mathrm{~mm})\end{array}$ & $\begin{array}{c}\mathrm{b}_{\mathrm{B}} \\
(\mathrm{mm})\end{array}$ & $\begin{array}{c}\mathrm{d} \\
(\mathrm{mm})\end{array}$ & $\underset{\left(\mathrm{m}^{2}\right)}{\mathrm{A}}$ & $\begin{array}{l}W \\
\text { (J) }\end{array}$ & $\begin{array}{c}W_{\text {empty }} \\
\text { (J) }\end{array}$ & $\begin{array}{c}\text { W }_{\text {corr }} \\
(\mathrm{kJ})\end{array}$ & $\underset{\left(\mathrm{kJ} / \mathrm{m}^{2}\right)}{\mathrm{a}_{\mathrm{cN}}}$ & Note \\
\hline P1 & 79.55 & 10.05 & 3.87 & 0.000039 & 0.234 & 0.008 & 0.000226 & 5.8 & \\
\hline P2 & 78.61 & 10.03 & 3.61 & 0.000036 & 0.289 & 0.008 & 0.000281 & 7.8 & \\
\hline P3 & 78.66 & 9.96 & 3.75 & 0.000037 & 0.311 & 0.008 & 0.000303 & 8.1 & \\
\hline P4 & 78.37 & 9.95 & 3.63 & 0.000036 & 0.318 & 0.008 & 0.000310 & 8.6 & \\
\hline P5 & 78.59 & 9.81 & 3.65 & 0.000036 & 0.325 & 0.008 & 0.000317 & 8.9 & \\
\hline P6 & 78.56 & 8.35 & 3.65 & 0.000030 & 0.073 & 0.007 & 0.000066 & 2.2 & \\
\hline P7 & 78.51 & 8.21 & 3.65 & 0.000030 & 0.097 & 0.007 & 0.000090 & 3.0 & \\
\hline P8 & 78.75 & 8.62 & 3.59 & 0.000031 & 0.084 & 0.007 & 0.000077 & 2.5 & \\
\hline P9 & 78.21 & 8.35 & 3.68 & 0.000031 & 0.086 & 0.007 & 0.000079 & 2.6 & \\
\hline P10 & 78.60 & 8.18 & 3.63 & 0.000030 & 0.088 & 0.007 & 0.000081 & 2.7 & \\
\hline
\end{tabular}


Table A21. Results of the notched impact tests and unnotched impact tests of PO_A,W,C.

\begin{tabular}{|c|c|c|c|c|c|c|c|c|c|}
\hline $\begin{array}{l}\text { Sample } \\
\text { Number }\end{array}$ & $\begin{array}{c}1 \\
(\mathrm{~mm})\end{array}$ & $\begin{array}{c}b_{B} \\
(\mathrm{~mm})\end{array}$ & $\begin{array}{c}\mathrm{d} \\
(\mathrm{mm})\end{array}$ & $\underset{\left(\mathrm{m}^{2}\right)}{\mathrm{A}}$ & $\begin{array}{l}W \\
(J)\end{array}$ & $\begin{array}{c}W_{\text {empty }} \\
\text { (J) }\end{array}$ & $\begin{array}{c}\mathrm{W}_{\text {corr }} \\
(\mathrm{kJ})\end{array}$ & $\underset{\left(\mathrm{kJ} / \mathrm{m}^{2}\right)}{\mathrm{a}_{\mathrm{cN}}}$ & Note \\
\hline P1 & 78.96 & 9.90 & 3.61 & 0.000036 & 0.232 & 0.007 & 0.000225 & 6.3 & \\
\hline P2 & 79.11 & 9.89 & 3.85 & 0.000038 & 0.245 & 0.007 & 0.000238 & 6.3 & \\
\hline P3 & 78.71 & 9.97 & 3.59 & 0.000036 & 0.231 & 0.007 & 0.000224 & 6.3 & \\
\hline P4 & 78.62 & 9.98 & 3.61 & 0.000036 & 0.214 & 0.007 & 0.000207 & 5.7 & \\
\hline P5 & 78.48 & 10.04 & 3.57 & 0.000036 & 0.321 & 0.007 & 0.000314 & 8.8 & \\
\hline P6 & 79.21 & 7.94 & 3.54 & 0.000028 & 0.105 & 0.007 & 0.000098 & 3.5 & \\
\hline P7 & 79.15 & 8.14 & 3.53 & 0.000029 & 0.106 & 0.007 & 0.000099 & 3.4 & \\
\hline P8 & 79.42 & 8.02 & 3.88 & 0.000031 & 0.106 & 0.007 & 0.000099 & 3.2 & \\
\hline P9 & 79.10 & 8.00 & 3.57 & 0.000029 & 0.105 & 0.007 & 0.000098 & 3.4 & \\
\hline P10 & 79.20 & 8.08 & 3.57 & 0.000029 & 0.105 & 0.007 & 0.000098 & 3.4 & \\
\hline
\end{tabular}

Table A22. Results of the notched impact tests and unnotched impact tests of PO_B.

\begin{tabular}{|c|c|c|c|c|c|c|c|c|c|}
\hline $\begin{array}{l}\text { Sample } \\
\text { Number }\end{array}$ & $\begin{array}{c}1 \\
(\mathrm{~mm})\end{array}$ & $\begin{array}{c}\mathrm{b}_{\mathrm{B}} \\
(\mathrm{mm})\end{array}$ & $\begin{array}{c}\mathrm{d} \\
(\mathrm{mm})\end{array}$ & $\underset{\left(\mathrm{m}^{2}\right)}{\mathrm{A}}$ & $\begin{array}{l}W \\
(J)\end{array}$ & $\begin{array}{c}W_{\text {empty }} \\
\text { (J) }\end{array}$ & $\begin{array}{c}\mathbf{W}_{\text {corr }} \\
(\mathrm{kJ})\end{array}$ & $\underset{\left(k J / m^{2}\right)}{a_{c N}}$ & Note \\
\hline P1 & 78.79 & 9.96 & 3.61 & 0.000036 & 0.202 & 0.008 & 0.000194 & 5.4 & partially broken \\
\hline P2 & 78.55 & 9.96 & 3.57 & 0.000036 & 0.342 & 0.008 & 0.000334 & 9.4 & partially broken \\
\hline P3 & 78.90 & 9.92 & 3.56 & 0.000035 & 0.284 & 0.008 & 0.000276 & 7.8 & partially broken \\
\hline $\mathrm{P} 4$ & 78.42 & 9.97 & 3.61 & 0.000036 & 0.390 & 0.008 & 0.000382 & 10.6 & \\
\hline P5 & 78.49 & 10.02 & 3.53 & 0.000035 & 0.245 & 0.008 & 0.000237 & 6.7 & partially broken \\
\hline P6 & 78.46 & 8.08 & 3.69 & 0.000030 & 0.206 & 0.007 & 0.000199 & 6.7 & \\
\hline P7 & 78.41 & 7.95 & 3.50 & 0.000028 & 0.183 & 0.007 & 0.000176 & 6.3 & partially broken \\
\hline P8 & 78.55 & 7.92 & 3.59 & 0.000028 & 0.147 & 0.007 & 0.000140 & 4.9 & partially broken \\
\hline P9 & 78.53 & 7.94 & 3.52 & 0.000028 & 0.195 & 0.007 & 0.000188 & 6.7 & \\
\hline P10 & 78.39 & 7.85 & 3.77 & 0.000030 & 0.245 & 0.007 & 0.000238 & 8.0 & \\
\hline
\end{tabular}

Table A23. Results of the notched impact tests and unnotched impact tests of PO_B,C.

\begin{tabular}{|c|c|c|c|c|c|c|c|c|c|}
\hline $\begin{array}{l}\text { Sample } \\
\text { Number }\end{array}$ & $\begin{array}{c}1 \\
(\mathrm{~mm})\end{array}$ & $\begin{array}{c}b_{B} \\
(\mathrm{~mm})\end{array}$ & $\begin{array}{c}\mathrm{d} \\
(\mathrm{mm})\end{array}$ & $\begin{array}{c}\mathrm{A} \\
\left(\mathrm{m}^{2}\right)\end{array}$ & $\begin{array}{l}W \\
(J)\end{array}$ & $\begin{array}{c}W_{\text {empty }} \\
\text { (J) }\end{array}$ & $\begin{array}{c}W_{\text {corr }} \\
(\mathrm{kJ})\end{array}$ & $\begin{array}{c}\mathrm{a}_{\mathrm{cN}} \\
\left(\mathrm{kJ} / \mathrm{m}^{2}\right)\end{array}$ & Note \\
\hline P1 & 78.64 & 9.99 & 3.51 & 0.000035 & 0.708 & 0.004 & 0.000704 & 20.1 & \\
\hline P2 & 78.58 & 9.93 & 3.52 & 0.000035 & 0.820 & 0.004 & 0.000816 & 23.3 & \\
\hline P3 & 78.72 & 10.00 & 3.56 & 0.000036 & 0.676 & 0.004 & 0.000672 & 18.9 & \\
\hline P4 & 78.72 & 9.95 & 3.60 & 0.000036 & 0.680 & 0.004 & 0.000676 & 18.9 & \\
\hline P5 & 78.61 & 9.99 & 3.54 & 0.000035 & 0.596 & 0.004 & 0.000592 & 16.7 & \\
\hline P6 & 78.68 & 8.08 & 3.56 & 0.000029 & 0.121 & 0.007 & 0.000114 & 4.0 & \\
\hline P7 & 78.70 & 7.95 & 3.58 & 0.000028 & 0.111 & 0.007 & 0.000104 & 3.7 & \\
\hline P8 & 78.72 & 7.92 & 3.57 & 0.000028 & 0.106 & 0.007 & 0.000099 & 3.5 & \\
\hline P9 & 78.70 & 7.94 & 3.55 & 0.000028 & 0.113 & 0.007 & 0.000106 & 3.8 & \\
\hline P10 & 78.81 & 7.85 & 3.56 & 0.000028 & 0.112 & 0.007 & 0.000105 & 3.8 & \\
\hline
\end{tabular}


Table A24. Results of the notched impact tests and unnotched impact tests of P.

\begin{tabular}{|c|c|c|c|c|c|c|c|c|c|}
\hline $\begin{array}{l}\text { Sample } \\
\text { Number }\end{array}$ & $\begin{array}{c}1 \\
(\mathrm{~mm})\end{array}$ & $\begin{array}{c}b_{B} \\
(\mathrm{~mm})\end{array}$ & $\underset{(\mathrm{mm})}{\mathrm{d}}$ & $\begin{array}{c}\text { A } \\
\left(\mathrm{m}^{2}\right)\end{array}$ & $\begin{array}{l}W \\
(J)\end{array}$ & $\begin{array}{c}W_{\text {leer }} \\
\text { (J) }\end{array}$ & $\begin{array}{c}W_{\text {empty }} \\
\text { (kJ) }\end{array}$ & $\begin{array}{c}a_{\mathrm{cN}} \\
\left(\mathrm{kJ} / \mathrm{m}^{2}\right)\end{array}$ & Note \\
\hline P1 & 78.72 & 10.07 & 4.08 & 0.000041 & 0.162 & 0.008 & 0.000154 & 3.7 & parcially broken \\
\hline P2 & 79.23 & 10.16 & 3.87 & 0.000039 & 0.214 & 0.008 & 0.000206 & 5.2 & parcially broken \\
\hline P3 & 79.14 & 10.32 & 3.88 & 0.000040 & 0.189 & 0.008 & 0.000181 & 4.5 & parcially broken \\
\hline $\mathrm{P} 4$ & 79.20 & 10.15 & 3.87 & 0.000039 & 0.151 & 0.008 & 0.000143 & 3.6 & parcially broken \\
\hline P5 & 79.10 & 10.17 & 4.15 & 0.000042 & 0.231 & 0.008 & 0.000223 & 5.3 & parcially broken \\
\hline P6 & 79.00 & 8.43 & 3.88 & 0.000033 & 0.129 & 0.007 & 0.000122 & 3.7 & \\
\hline P7 & 79.17 & 8.05 & 3.95 & 0.000032 & 0.155 & 0.007 & 0.000148 & 4.7 & \\
\hline P8 & 79.28 & 8.01 & 3.93 & 0.000031 & 0.135 & 0.007 & 0.000128 & 4.1 & \\
\hline P9 & 79.24 & 8.02 & 3.89 & 0.000031 & 0.143 & 0.007 & 0.000136 & 4.4 & \\
\hline P10 & 79.20 & 8.01 & 3.97 & 0.000032 & 0.138 & 0.007 & 0.000131 & 4.1 & \\
\hline
\end{tabular}

Table A25. Results of the notched impact tests and unnotched impact tests of P_C.

\begin{tabular}{|c|c|c|c|c|c|c|c|c|c|}
\hline $\begin{array}{l}\text { Sample } \\
\text { Number }\end{array}$ & $\begin{array}{c}1 \\
(\mathrm{~mm})\end{array}$ & $\begin{array}{c}b_{B} \\
(\mathrm{~mm})\end{array}$ & $\underset{(\mathrm{mm})}{\mathrm{d}}$ & $\begin{array}{c}\mathrm{A} \\
\left(\mathrm{m}^{2}\right)\end{array}$ & $\begin{array}{l}W \\
\text { (J) }\end{array}$ & $\begin{array}{c}W_{\text {empty }} \\
\text { (J) }\end{array}$ & $\begin{array}{c}\mathbf{W}_{\text {corr }} \\
(\mathrm{kJ})\end{array}$ & $\begin{array}{c}a_{\mathrm{cN}} \\
\left(\mathrm{kJ} / \mathrm{m}^{2}\right)\end{array}$ & Note \\
\hline P1 & 79.23 & 9.92 & 3.65 & 0.000036 & 0.184 & 0.008 & 0.000176 & 4.9 & \\
\hline P2 & 78.38 & 10.05 & 3.72 & 0.000037 & 0.132 & 0.008 & 0.000124 & 3.3 & \\
\hline P3 & 78.42 & 10.01 & 3.69 & 0.000037 & 0.235 & 0.008 & 0.000227 & 6.1 & \\
\hline P4 & 78.42 & 9.97 & 3.65 & 0.000036 & 0.169 & 0.008 & 0.000161 & 4.4 & \\
\hline P5 & 78.19 & 9.95 & 3.66 & 0.000036 & 0.188 & 0.008 & 0.000180 & 4.9 & \\
\hline P6 & 79.47 & 7.98 & 3.70 & 0.000030 & 0.077 & 0.007 & 0.000070 & 2.4 & \\
\hline P7 & 78.38 & 8.00 & 3.67 & 0.000029 & 0.074 & 0.007 & 0.000067 & 2.3 & \\
\hline P8 & 79.41 & 7.97 & 3.69 & 0.000029 & 0.078 & 0.007 & 0.000071 & 2.4 & \\
\hline P9 & 79.55 & 7.96 & 3.70 & 0.000029 & 0.066 & 0.007 & 0.000059 & 2.0 & \\
\hline P10 & 79.35 & 8.06 & 3.67 & 0.000030 & 0.083 & 0.007 & 0.000076 & 2.6 & \\
\hline
\end{tabular}




\section{Appendix F. Tensile Tests}

Table A26. Results of the tensile tests of P_PE.

\begin{tabular}{|c|c|c|c|c|c|c|c|c|c|c|c|c|c|c|c|c|c|}
\hline $\begin{array}{l}\text { Sample } \\
\text { Number }\end{array}$ & $\begin{array}{l}\text { Curve } \\
\text { Type }\end{array}$ & $\begin{array}{c}\mathrm{E}_{\mathrm{t}} \\
(\mathrm{MPa})\end{array}$ & $\begin{array}{c}\mathrm{s}_{\mathrm{y}} \\
(\mathrm{MPa})\end{array}$ & $\begin{array}{l}F_{y} \\
(N)\end{array}$ & $\begin{array}{c}e_{y} \\
(\%)\end{array}$ & $\begin{array}{c}\mathbf{e}_{\mathbf{Y}} \\
(\mathrm{mm})\end{array}$ & $\begin{array}{c}\mathrm{s}_{\mathrm{m}} \\
(\mathrm{MPa})\end{array}$ & $\begin{array}{l}\mathrm{s}_{\mathrm{M}} \\
(\mathrm{N})\end{array}$ & $\begin{array}{l}e_{m} \\
(\%)\end{array}$ & $\underset{(\mathrm{mm})}{\mathbf{e}_{M}}$ & $\begin{array}{c}\mathrm{s}_{\mathrm{b}} \\
(\mathrm{MPa})\end{array}$ & $\begin{array}{l}\mathrm{s}_{\mathrm{B}} \\
(\mathrm{N})\end{array}$ & $\begin{array}{l}e_{b} \\
(\%)\end{array}$ & $\underset{(\mathrm{mm})}{\mathbf{e}_{\mathrm{B}}}$ & $\begin{array}{c}\mathrm{b} \\
(\mathrm{mm})\end{array}$ & $\begin{array}{c}\mathrm{h} \\
(\mathrm{mm})\end{array}$ & $\underset{\left(\mathrm{mm}^{2}\right)}{\mathrm{A}_{0}}$ \\
\hline P1 & c & 532.0 & 9.12 & 325.6 & 6.06 & 3.028 & 9.12 & 325.6 & 6.06 & 3.028 & 8.227 & 293.7 & 7.08 & 3.54 & 9.89 & 3.61 & 35.70 \\
\hline P2 & a & 560.6 & - & - & - & - & 8.67 & 320.9 & 4.44 & 2.219 & 8.393 & 310.6 & 4.93 & 2.47 & 10 & 3.7 & 37.00 \\
\hline P3 & c & 579.0 & 9.19 & 329.4 & 5.43 & 2.714 & 9.19 & 329.4 & 5.43 & 2.714 & 1.836 & 65.9 & 7.36 & 3.68 & 9.88 & 3.63 & 35.86 \\
\hline $\mathrm{P} 4$ & a & 550.6 & - & - & - & - & 8.30 & 292.5 & 3.48 & 1.738 & 7.969 & 281.0 & 3.81 & 1.90 & 9.85 & 3.58 & 35.26 \\
\hline P5 & c & 593.3 & - & - & - & - & 8.61 & 315.9 & 3.79 & 1.897 & 8.404 & 308.4 & 3.93 & 1.96 & 9.89 & 3.71 & 36.69 \\
\hline P6 & c & 551.5 & 9.01 & 321.2 & 5.17 & 2.586 & 9.01 & 321.2 & 5.17 & 2.586 & 8.320 & 296.5 & 6.13 & 3.07 & 9.9 & 3.6 & 35.64 \\
\hline \multicolumn{2}{|c|}{ Mean value } & 561.2 & 9.11 & 325.4 & 5.55 & 2.776 & 8.82 & 317.6 & 4.73 & 2.363 & 7.192 & 259.3 & 5.54 & 2.77 & & & \\
\hline \multicolumn{2}{|c|}{$\begin{array}{l}\text { Standard } \\
\text { deviation }\end{array}$} & 21.9 & 0.09 & 4.1 & 0.45 & 0.227 & 0.35 & 13.1 & 1.00 & 0.499 & 2.628 & 95.4 & 1.55 & 0.77 & & & \\
\hline \multicolumn{2}{|c|}{$\begin{array}{c}\text { Relative } \\
\text { deviation [\%] }\end{array}$} & 3.91 & 0.97 & 1.27 & 8.18 & 8.18 & 3.93 & 4.13 & 21.10 & 21.10 & 36.55 & 36.78 & 27.94 & 27.95 & & & \\
\hline
\end{tabular}

Table A27. Results of the tensile tests of $P_{-} W, P E$.

\begin{tabular}{|c|c|c|c|c|c|c|c|c|c|c|c|c|c|}
\hline $\begin{array}{l}\text { Sample } \\
\text { Number }\end{array}$ & $\begin{array}{l}\text { Curve } \\
\text { Type }\end{array}$ & $\begin{array}{c}E_{t} \\
(\mathrm{MPa})\end{array}$ & $\begin{array}{c}\mathrm{s}_{\mathrm{m}} \\
(\mathrm{MPa})\end{array}$ & $\begin{array}{l}F_{M} \\
(\mathbf{N})\end{array}$ & $\begin{array}{l}e_{m} \\
(\%)\end{array}$ & $\begin{array}{c}e_{M} \\
(\mathrm{~mm})\end{array}$ & $\begin{array}{c}\mathrm{s}_{\mathrm{b}} \\
(\mathrm{MPa})\end{array}$ & $\begin{array}{c}\mathbf{s}_{\mathbf{B}} \\
(\mathbf{N})\end{array}$ & $\begin{array}{l}e_{b} \\
(\%)\end{array}$ & $\begin{array}{c}e_{B} \\
(\mathrm{~mm})\end{array}$ & $\begin{array}{c}\mathbf{b} \\
(\mathrm{mm})\end{array}$ & $\begin{array}{c}\mathrm{h} \\
(\mathrm{mm})\end{array}$ & $\begin{array}{c}\mathrm{A}_{0} \\
\left(\mathrm{~mm}^{2}\right)\end{array}$ \\
\hline P1 & c & 486.5 & 9.04 & 321.2 & 7.21 & 3.604 & 6.472 & 230.0 & 9.75 & 4.87 & 10.04 & 3.54 & 35.54 \\
\hline P2 & c & 498.6 & 9.13 & 324.5 & 5.68 & 2.842 & 8.884 & 315.7 & 6.00 & 3.00 & 10.01 & 3.55 & 35.54 \\
\hline P3 & c & 459.6 & 9.16 & 330.1 & 6.70 & 3.352 & 9.163 & 330.1 & 6.70 & 3.35 & 9.98 & 3.61 & 36.03 \\
\hline P4 & c & 494.7 & 8.82 & 314.8 & 6.63 & 3.316 & 8.824 & 314.8 & 6.63 & 3.32 & 10.05 & 3.55 & 35.68 \\
\hline P5 & c & 483.5 & 8.12 & 291.8 & 3.95 & 1.973 & 7.898 & 284.0 & 4.16 & 2.08 & 10.1 & 3.56 & 35.96 \\
\hline P6 & c & 497.0 & 8.75 & 306.7 & 5.94 & 2.970 & 8.753 & 306.7 & 5.94 & 2.97 & 10.04 & 3.49 & 35.04 \\
\hline \multicolumn{2}{|c|}{ Mean value } & 486.6 & 8.84 & 314.9 & 6.02 & 3.010 & 8.33 & 296.9 & 6.53 & 3.265 & & & \\
\hline \multicolumn{2}{|c|}{ Standard deviation } & 14.5 & 0.39 & 13.9 & 1.16 & 0.578 & 1.01 & 36.1 & 1.82 & 0.912 & & & \\
\hline \multicolumn{2}{|c|}{ Relative deviation [\%] } & 2.98 & 4.42 & 4.41 & 19.20 & 19.20 & 12.08 & 12.16 & 27.93 & 27.93 & & & \\
\hline
\end{tabular}


Table A28. Results of the tensile tests of P_C,PE.

\begin{tabular}{|c|c|c|c|c|c|c|c|c|c|c|c|c|c|}
\hline $\begin{array}{c}\text { Sample } \\
\text { Number }\end{array}$ & $\begin{array}{l}\text { Curve } \\
\text { Type }\end{array}$ & $\begin{array}{c}\mathrm{E}_{\mathrm{t}} \\
(\mathrm{MPa})\end{array}$ & $\begin{array}{c}\mathrm{s}_{\mathrm{m}} \\
(\mathrm{MPa})\end{array}$ & $\begin{array}{l}\mathbf{F}_{M} \\
(\mathrm{~N})\end{array}$ & $\begin{array}{l}e_{m} \\
(\%)\end{array}$ & $\underset{(\mathrm{mm})}{\mathbf{e}_{M}}$ & $\begin{array}{c}\mathrm{s}_{\mathrm{b}} \\
(\mathrm{MPa})\end{array}$ & $\begin{array}{l}\mathrm{s}_{\mathrm{B}} \\
(\mathrm{N})\end{array}$ & $\begin{array}{l}e_{b} \\
(\%)\end{array}$ & $\underset{(\mathrm{mm})}{\mathrm{e}_{\mathrm{B}}}$ & $\begin{array}{c}\mathbf{b} \\
(\mathrm{mm})\end{array}$ & $\underset{(\mathrm{mm})}{\mathrm{h}}$ & $\begin{array}{c}\mathbf{A}_{0} \\
\left(\mathbf{m m}^{2}\right)\end{array}$ \\
\hline P1 & a & 540.2 & 10.89 & 389.8 & 9.03 & 4.513 & 10.621 & 380.0 & 10.30 & 5.15 & 9.94 & 3.6 & 35.78 \\
\hline P2 & $\mathrm{a}$ & 537.2 & 11.10 & 397.3 & 11.82 & 5.911 & 10.593 & 379.3 & 15.06 & 7.53 & 9.89 & 3.62 & 35.80 \\
\hline P3 & $\mathrm{a}$ & 574.2 & 10.71 & 388.4 & 8.67 & 4.337 & 10.406 & 377.4 & 9.42 & 4.71 & 9.91 & 3.66 & 36.27 \\
\hline $\mathrm{P} 4$ & a & 557.6 & 10.58 & 378.8 & 6.22 & 3.111 & 10.481 & 375.2 & 6.41 & 3.21 & 9.89 & 3.62 & 35.80 \\
\hline P5 & $\mathrm{a}$ & 533.2 & 10.90 & 390.8 & 9.78 & 4.890 & 10.517 & 377.0 & 11.20 & 5.60 & 9.93 & 3.61 & 35.85 \\
\hline P6 & $\mathrm{a}$ & 540.8 & 10.91 & 391.0 & 9.70 & 4.850 & 10.611 & 380.3 & 10.73 & 5.36 & 10.01 & 3.58 & 35.84 \\
\hline \multicolumn{2}{|c|}{ Mean value } & 547.2 & 10.85 & 389.4 & 9.20 & 4.602 & 10.538 & 378.2 & 10.52 & 5.26 & & & \\
\hline \multicolumn{2}{|c|}{ Standard deviation } & 15.6 & 0.18 & 6.0 & 1.82 & 0.912 & 0.085 & 2.0 & 2.80 & 1.40 & & & \\
\hline \multicolumn{2}{|c|}{ Relative deviation [\%] } & 2.86 & 1.66 & 1.54 & 19.82 & 19.82 & 0.81 & 0.52 & 26.64 & 26.64 & & & \\
\hline
\end{tabular}

Table A29. Results of the tensile tests of $P_{-} W, C, P E$.

\begin{tabular}{|c|c|c|c|c|c|c|c|c|c|c|c|c|c|c|c|c|c|}
\hline $\begin{array}{l}\text { Sample } \\
\text { Number }\end{array}$ & $\begin{array}{l}\text { Curve } \\
\text { Type }\end{array}$ & $\begin{array}{c}\mathrm{E}_{\mathrm{t}} \\
(\mathrm{MPa})\end{array}$ & $\begin{array}{c}\mathrm{s}_{\mathrm{y}} \\
(\mathrm{MPa})\end{array}$ & $\begin{array}{l}F_{y} \\
(\mathbf{N})\end{array}$ & $\begin{array}{c}\mathrm{e}_{\mathrm{y}} \\
(\%)\end{array}$ & $\begin{array}{c}\mathbf{e}_{Y} \\
(\mathrm{~mm})\end{array}$ & $\begin{array}{c}\mathrm{s}_{\mathrm{m}} \\
(\mathrm{MPa})\end{array}$ & $\begin{array}{l}\mathrm{s}_{\mathrm{M}} \\
(\mathrm{N})\end{array}$ & $\begin{array}{l}e_{m} \\
(\%)\end{array}$ & $\begin{array}{c}\mathbf{e}_{M} \\
(\mathrm{~mm})\end{array}$ & $\begin{array}{c}\mathrm{s}_{\mathrm{b}} \\
(\mathrm{MPa})\end{array}$ & $\begin{array}{c}\mathrm{S}_{\mathrm{B}} \\
(\mathrm{N})\end{array}$ & $\begin{array}{c}e_{b} \\
(\%)\end{array}$ & $\underset{(\mathrm{mm})}{\mathbf{e}_{\mathbf{B}}}$ & $\begin{array}{c}b \\
(\mathrm{~mm})\end{array}$ & $\begin{array}{c}\mathrm{h} \\
(\mathrm{mm})\end{array}$ & $\begin{array}{c}\mathrm{A}_{0} \\
\left(\mathrm{~mm}^{2}\right)\end{array}$ \\
\hline P1 & c & 499.2 & 12.14 & 429.7 & 11.45 & 5.727 & 12.14 & 429.7 & 11.45 & 5.727 & 9.511 & 336.8 & 44.26 & 22.13 & 9.89 & 3.58 & 35.41 \\
\hline P2 & c & 533.9 & 12.26 & 435.7 & 11.56 & 5.781 & 12.26 & 435.7 & 11.56 & 5.781 & 8.435 & 299.7 & 49.63 & 24.82 & 9.87 & 3.6 & 35.53 \\
\hline P3 & c & 526.4 & 12.23 & 435.4 & 12.30 & 6.150 & 12.23 & 435.4 & 12.30 & 6.150 & 5.915 & 210.6 & 53.86 & 26.93 & 9.86 & 3.61 & 35.59 \\
\hline P4 & c & 539.7 & 12.36 & 436.6 & 12.39 & 6.193 & 12.36 & 436.6 & 12.39 & 6.193 & 4.356 & 153.9 & 43.94 & 21.97 & 9.84 & 3.59 & 35.33 \\
\hline P5 & c & 535.3 & 12.34 & 431.0 & 11.57 & 5.784 & 12.34 & 431.0 & 11.57 & 5.784 & 3.918 & 136.9 & 46.26 & 23.13 & 9.84 & 3.55 & 34.93 \\
\hline P6 & c & 578.9 & 12.56 & 449.8 & 12.31 & 6.154 & 12.56 & 449.8 & 12.31 & 6.154 & 4.634 & 166.0 & 52.04 & 26.02 & 9.87 & 3.63 & 35.83 \\
\hline \multicolumn{2}{|c|}{ Mean value } & 535.6 & 12.31 & 436.4 & 11.93 & 5.965 & 12.31 & 436.4 & 11.93 & 5.965 & 6.128 & 217.3 & 48.33 & 24.17 & - & - & - \\
\hline \multicolumn{2}{|c|}{$\begin{array}{l}\text { Standard } \\
\text { deviation }\end{array}$} & 25.7 & 0.14 & 7.2 & 0.44 & 0.221 & 0.14 & 7.2 & 0.44 & 0.221 & 2.327 & 82.7 & 4.15 & 2.08 & - & - & - \\
\hline \multicolumn{2}{|c|}{$\begin{array}{c}\text { Relative } \\
\text { deviation [\%] }\end{array}$} & 4.80 & 1.16 & 1.64 & 3.71 & 3.71 & 1.16 & 1.64 & 3.71 & 3.71 & 37.97 & 38.07 & 8.59 & 8.59 & - & - & - \\
\hline
\end{tabular}


Table A30. Results of the tensile tests of P_PP.

\begin{tabular}{|c|c|c|c|c|c|c|c|c|c|c|c|c|c|}
\hline $\begin{array}{l}\text { Sample } \\
\text { Number }\end{array}$ & $\begin{array}{c}\text { Curve } \\
\text { Type }\end{array}$ & $\begin{array}{c}\mathrm{E}_{\mathrm{t}} \\
(\mathrm{MPa})\end{array}$ & $\begin{array}{c}\mathrm{s}_{\mathrm{m}} \\
(\mathrm{MPa})\end{array}$ & $\begin{array}{l}F_{M} \\
(N)\end{array}$ & $\begin{array}{l}e_{m} \\
(\%)\end{array}$ & $\begin{array}{c}\mathrm{e}_{\mathrm{M}} \\
(\mathrm{mm})\end{array}$ & $\begin{array}{c}\mathrm{s}_{\mathrm{b}} \\
(\mathrm{MPa})\end{array}$ & $\begin{array}{l}\mathbf{s}_{\mathbf{B}} \\
(\mathbf{N})\end{array}$ & $\begin{array}{l}e_{b} \\
(\%)\end{array}$ & $\begin{array}{c}e_{B} \\
(\mathrm{~mm})\end{array}$ & $\begin{array}{c}\mathrm{b} \\
(\mathrm{mm})\end{array}$ & $\begin{array}{c}\mathrm{h} \\
(\mathrm{mm})\end{array}$ & $\begin{array}{c}\mathrm{A}_{0} \\
\left(\mathrm{~mm}^{2}\right)\end{array}$ \\
\hline P1 & $\mathrm{a}$ & 1373.1 & 13.09 & 469.8 & 1.69 & 0.843 & 12.596 & 452.2 & 1.84 & 0.92 & 10 & 3.59 & 35.90 \\
\hline P2 & $\mathrm{a}$ & 1435.4 & 13.19 & 473.4 & 1.64 & 0.820 & 13.186 & 473.4 & 1.64 & 0.82 & 10 & 3.59 & 35.90 \\
\hline P3 & a & 1399.6 & 11.65 & 418.2 & 1.30 & 0.648 & 11.648 & 418.2 & 1.30 & 0.65 & 10 & 3.59 & 35.90 \\
\hline $\mathrm{P} 4$ & $\mathrm{a}$ & 1414.2 & 11.88 & 426.7 & 1.24 & 0.620 & 11.884 & 426.7 & 1.24 & 0.62 & 10 & 3.59 & 35.90 \\
\hline P5 & $\mathrm{a}$ & 1380.5 & 10.16 & 364.8 & 0.97 & 0.487 & 10.035 & 360.3 & 0.99 & 0.50 & 10 & 3.59 & 35.90 \\
\hline P6 & $\mathrm{a}$ & 1467.9 & 11.01 & 395.4 & 1.02 & 0.508 & 11.014 & 395.4 & 1.02 & 0.51 & 10 & 3.59 & 35.90 \\
\hline \multicolumn{2}{|c|}{ Mean value } & 1411.8 & 11.83 & 424.7 & 1.31 & 0.655 & 11.727 & 421.0 & 1.34 & 0.67 & - & - & - \\
\hline \multicolumn{2}{|c|}{ Standard deviation } & 35.6 & 1.17 & 42.2 & 0.30 & 0.151 & 1.121 & 40.3 & 0.34 & 0.17 & - & - & - \\
\hline \multicolumn{2}{|c|}{ Relative deviation [\%] } & 2.52 & 9.93 & 9.93 & 23.01 & 23.01 & 9.56 & 9.56 & 25.35 & 25.35 & - & - & - \\
\hline
\end{tabular}

Table A31. Results of the tensile tests of P_W,PP.

\begin{tabular}{|c|c|c|c|c|c|c|c|c|c|c|c|c|c|}
\hline $\begin{array}{l}\text { Sample } \\
\text { Number }\end{array}$ & $\begin{array}{l}\text { Curve } \\
\text { Type }\end{array}$ & $\begin{array}{c}\mathrm{E}_{\mathrm{t}} \\
(\mathrm{MPa})\end{array}$ & $\begin{array}{c}\mathrm{s}_{\mathrm{m}} \\
(\mathrm{MPa})\end{array}$ & $\begin{array}{l}F_{M} \\
(N)\end{array}$ & $\begin{array}{l}\mathbf{e}_{\mathrm{m}} \\
(\%)\end{array}$ & $\underset{(\mathrm{mm})}{\mathbf{e}_{\mathrm{M}}}$ & $\begin{array}{c}\mathrm{s}_{\mathrm{b}} \\
(\mathrm{MPa})\end{array}$ & $\begin{array}{c}\mathrm{s}_{\mathrm{B}} \\
(\mathrm{N})\end{array}$ & $\begin{array}{l}e_{b} \\
(\%)\end{array}$ & $\underset{(\mathrm{mm})}{\mathbf{e}_{\mathbf{B}}}$ & $\begin{array}{c}\mathbf{b} \\
(\mathrm{mm})\end{array}$ & $\begin{array}{c}\mathrm{h} \\
(\mathrm{mm})\end{array}$ & $\begin{array}{c}\mathbf{A}_{0} \\
\left(\mathrm{~mm}^{2}\right)\end{array}$ \\
\hline P1 & a & 1509.3 & 15.69 & 555.8 & 1.50 & 0.748 & 15.690 & 555.8 & 1.50 & 0.75 & 10.15 & 3.49 & 35.42 \\
\hline $\mathrm{P} 2$ & a & 1517.7 & 18.16 & 657.4 & 2.50 & 1.250 & 18.160 & 657.4 & 2.50 & 1.25 & 10.14 & 3.57 & 36.20 \\
\hline P3 & a & 1508.4 & 18.65 & 678.4 & 2.48 & 1.242 & 18.654 & 678.4 & 2.48 & 1.24 & 10.13 & 3.59 & 36.37 \\
\hline $\mathrm{P} 4$ & a & 1552.9 & 17.90 & 644.2 & 2.30 & 1.150 & 17.897 & 644.2 & 2.30 & 1.15 & 10.14 & 3.55 & 36.00 \\
\hline P5 & a & 1452.3 & 17.58 & 642.2 & 2.30 & 1.150 & 17.579 & 642.2 & 2.30 & 1.15 & 10.29 & 3.55 & 36.53 \\
\hline P6 & a & 1502.7 & 18.21 & 652.6 & 2.58 & 1.292 & 18.213 & 652.6 & 2.58 & 1.29 & 10.18 & 3.52 & 35.83 \\
\hline \multicolumn{2}{|c|}{ Mean value } & 1507.2 & 17.70 & 638.4 & 2.28 & 1.139 & 17.699 & 638.4 & 2.28 & 1.14 & - & - & - \\
\hline \multicolumn{2}{|c|}{ Standard deviation } & 32.4 & 1.05 & 42.5 & 0.40 & 0.200 & 1.047 & 42.5 & 0.40 & 0.20 & - & - & - \\
\hline \multicolumn{2}{|c|}{ Relative deviation [\%] } & 2.15 & 5.92 & 6.66 & 17.54 & 17.54 & 5.92 & 6.66 & 17.54 & 17.54 & - & - & - \\
\hline
\end{tabular}


Table A32. Results of the tensile tests of P_C,PP.

\begin{tabular}{|c|c|c|c|c|c|c|c|c|c|c|c|c|c|}
\hline $\begin{array}{l}\text { Sample } \\
\text { Number }\end{array}$ & $\begin{array}{l}\text { Curve } \\
\text { Type }\end{array}$ & $\begin{array}{c}\mathrm{E}_{\mathrm{t}} \\
(\mathrm{MPa})\end{array}$ & $\begin{array}{c}\mathrm{s}_{\mathrm{m}} \\
(\mathrm{MPa})\end{array}$ & $\begin{array}{l}F_{M} \\
(\mathbf{N})\end{array}$ & $\begin{array}{l}e_{m} \\
(\%)\end{array}$ & $\begin{array}{c}\mathrm{e}_{\mathrm{M}} \\
(\mathrm{mm})\end{array}$ & $\begin{array}{c}\mathrm{s}_{\mathrm{b}} \\
(\mathrm{MPa})\end{array}$ & $\begin{array}{c}\mathrm{s}_{\mathrm{B}} \\
(\mathrm{N})\end{array}$ & $\begin{array}{l}e_{b} \\
(\%)\end{array}$ & $\begin{array}{c}e_{B} \\
(\mathrm{~mm})\end{array}$ & $\begin{array}{c}\mathrm{b} \\
(\mathrm{mm})\end{array}$ & $\begin{array}{c}\mathrm{h} \\
(\mathrm{mm})\end{array}$ & $\begin{array}{c}\mathbf{A}_{0} \\
\left(\mathrm{~mm}^{2}\right)\end{array}$ \\
\hline P1 & $\mathrm{a}$ & 1697.3 & 14.46 & 525.1 & 1.24 & 0.620 & 14.455 & 525.1 & 1.24 & 0.62 & 9.98 & 3.64 & 36.33 \\
\hline P2 & a & 1573.2 & 16.34 & 592.8 & 1.74 & 0.872 & 16.345 & 592.8 & 1.74 & 0.87 & 9.91 & 3.66 & 36.27 \\
\hline P3 & a & 1599.2 & 17.61 & 618.4 & 1.99 & 0.995 & 17.614 & 618.4 & 1.99 & 1.00 & 9.78 & 3.59 & 35.11 \\
\hline P4 & $\mathrm{a}$ & 1481.3 & 16.23 & 576.5 & 1.59 & 0.794 & 16.137 & 573.3 & 1.59 & 0.79 & 9.68 & 3.67 & 35.53 \\
\hline P5 & a & 1589.4 & 15.35 & 551.9 & 1.44 & 0.720 & 15.352 & 551.9 & 1.44 & 0.72 & 9.69 & 3.71 & 35.95 \\
\hline P6 & a & 1549.7 & 16.31 & 599.0 & 1.60 & 0.798 & 16.276 & 597.6 & 1.60 & 0.80 & 9.87 & 3.72 & 36.72 \\
\hline \multicolumn{2}{|c|}{ Mean value } & 1581.7 & 16.05 & 577.3 & 1.60 & 0.800 & 16.030 & 576.5 & 1.60 & 0.80 & - & - & - \\
\hline \multicolumn{2}{|c|}{ Standard deviation } & 70.6 & 1.06 & 34.0 & 0.26 & 0.128 & 1.060 & 33.8 & 0.26 & 0.13 & - & - & - \\
\hline \multicolumn{2}{|c|}{ Relative deviation [\%] } & 4.46 & 6.63 & 5.89 & 16.01 & 16.01 & 6.61 & 5.87 & 16.01 & 16.01 & - & - & - \\
\hline
\end{tabular}

Table A33. Results of the tensile tests of P_W,C,PP.

\begin{tabular}{|c|c|c|c|c|c|c|c|c|c|c|c|c|c|c|c|c|c|}
\hline $\begin{array}{l}\text { Sample } \\
\text { Number }\end{array}$ & $\begin{array}{l}\text { Curve } \\
\text { Type }\end{array}$ & $\begin{array}{c}E_{t} \\
(\mathrm{MPa})\end{array}$ & $\begin{array}{c}\mathrm{s}_{\mathrm{y}} \\
(\mathrm{MPa})\end{array}$ & $\begin{array}{l}F_{y} \\
(N)\end{array}$ & $\begin{array}{c}e_{y} \\
(\%)\end{array}$ & $\begin{array}{c}e_{Y} \\
(\mathrm{~mm})\end{array}$ & $\begin{array}{c}\mathrm{s}_{\mathrm{m}} \\
(\mathrm{MPa})\end{array}$ & $\begin{array}{l}\mathrm{s}_{\mathrm{M}} \\
(\mathrm{N})\end{array}$ & $\begin{array}{l}e_{m} \\
(\%)\end{array}$ & $\begin{array}{c}e_{M} \\
(\mathrm{~mm})\end{array}$ & $\begin{array}{c}\mathrm{s}_{\mathrm{b}} \\
(\mathrm{MPa})\end{array}$ & $\begin{array}{l}\mathbf{s}_{\mathbf{B}} \\
(\mathbf{N})\end{array}$ & $\begin{array}{l}e_{b} \\
(\%)\end{array}$ & $\begin{array}{c}\mathbf{e}_{B} \\
(\mathrm{~mm})\end{array}$ & $\begin{array}{c}\mathrm{b} \\
(\mathrm{mm})\end{array}$ & $\begin{array}{c}\mathrm{h} \\
(\mathrm{mm})\end{array}$ & $\begin{array}{c}\mathrm{A}_{0} \\
\left(\mathrm{~mm}^{2}\right)\end{array}$ \\
\hline P1 & a & 1484.0 & - & - & - & - & 23.88 & 869.9 & 3.88 & 1.942 & 23.880 & 869.9 & 3.88 & 1.94 & 9.98 & 3.65 & 36.43 \\
\hline P2 & a & 1556.5 & - & - & - & - & 21.07 & 765.5 & 3.28 & 1.638 & 21.069 & 765.5 & 3.28 & 1.64 & 9.9 & 3.67 & 36.33 \\
\hline P3 & c & 1542.1 & 17.54 & 638.0 & 2.14 & 1.071 & 17.54 & 638.0 & 2.14 & 1.071 & 10.456 & 380.3 & 2.89 & 1.45 & 9.91 & 3.67 & 36.37 \\
\hline $\mathrm{P} 4$ & a & 1282.4 & - & - & - & - & 21.20 & 778.5 & 3.57 & 1.783 & 21.202 & 778.5 & 3.57 & 1.78 & 9.87 & 3.72 & 36.72 \\
\hline P5 & a & 2039.3 & - & - & - & - & 20.64 & 746.1 & 3.50 & 1.749 & 19.999 & 722.9 & 3.72 & 1.86 & 9.93 & 3.64 & 36.15 \\
\hline P6 & a & 1616.8 & - & - & - & - & 20.87 & 758.9 & 3.55 & 1.776 & 20.867 & 758.9 & 3.55 & 1.78 & 9.91 & 3.67 & 36.37 \\
\hline \multicolumn{2}{|c|}{ Mean value } & 1586.9 & 17.54 & 638.0 & 2.14 & 1.071 & 20.87 & 759.5 & 3.32 & 1.660 & 19.579 & 712.7 & 3.48 & 1.74 & - & - & - \\
\hline \multicolumn{2}{|c|}{$\begin{array}{l}\text { Standard } \\
\text { deviation }\end{array}$} & 249.7 & - & - & - & - & 2.02 & 74.2 & 0.61 & 0.304 & 4.657 & 170.0 & 0.35 & 0.18 & - & - & - \\
\hline \multicolumn{2}{|c|}{$\begin{array}{c}\text { Relative } \\
\text { deviation [\%] }\end{array}$} & 15.74 & - & - & - & - & 9.66 & 9.77 & 18.34 & 18.34 & 23.78 & 23.86 & 10.09 & 10.07 & - & - & - \\
\hline
\end{tabular}


Table A34. Results of the tensile tests of P_PS.

\begin{tabular}{|c|c|c|c|c|c|c|c|c|c|c|c|c|c|c|c|c|c|}
\hline $\begin{array}{l}\text { Sample } \\
\text { Num- } \\
\text { ber }\end{array}$ & $\begin{array}{c}\text { Curve } \\
\text { Type }\end{array}$ & $\begin{array}{c}\mathrm{E}_{\mathrm{t}} \\
(\mathrm{MPa})\end{array}$ & $\begin{array}{c}\mathrm{s}_{\mathrm{y}} \\
(\mathrm{MPa})\end{array}$ & $\begin{array}{l}F_{y} \\
(N)\end{array}$ & $\begin{array}{c}e_{y} \\
(\%)\end{array}$ & $\begin{array}{c}\mathbf{e}_{\mathbf{Y}} \\
(\mathrm{mm})\end{array}$ & $\begin{array}{c}\mathrm{s}_{\mathrm{m}} \\
(\mathrm{MPa})\end{array}$ & $\begin{array}{l}\mathbf{s}_{\mathbf{M}} \\
(\mathbf{N})\end{array}$ & $\begin{array}{l}e_{m} \\
(\%)\end{array}$ & $\begin{array}{c}\mathbf{e}_{M} \\
(\mathrm{~mm})\end{array}$ & $\begin{array}{c}\mathrm{s}_{\mathrm{b}} \\
(\mathrm{MPa})\end{array}$ & $\begin{array}{l}\mathbf{S}_{\mathbf{B}} \\
(\mathbf{N})\end{array}$ & $\begin{array}{c}e_{b} \\
(\%)\end{array}$ & $\begin{array}{c}\mathrm{e}_{\mathrm{B}} \\
(\mathrm{mm})\end{array}$ & $\begin{array}{c}\mathrm{b} \\
(\mathrm{mm})\end{array}$ & $\begin{array}{c}\mathrm{h} \\
(\mathrm{mm})\end{array}$ & $\begin{array}{c}\mathbf{A}_{0} \\
\left(\mathrm{~mm}^{2}\right)\end{array}$ \\
\hline P1 & a & 924.8 & - & - & - & - & 5.83 & 216.3 & 0.78 & 0.391 & 5.664 & 210.1 & 0.79 & 0.40 & 10 & 3.71 & 37.10 \\
\hline $\mathrm{P} 2$ & a & 914.5 & - & - & - & - & 6.01 & 223.4 & 0.93 & 0.464 & 5.663 & 210.3 & 1.01 & 0.50 & 10.01 & 3.71 & 37.14 \\
\hline P3 & c & 1005.8 & 6.24 & 227.9 & 0.86 & 0.429 & 6.24 & 227.9 & 0.86 & 0.429 & 1.246 & 45.5 & 1.82 & 0.91 & 9.95 & 3.67 & 36.52 \\
\hline $\mathrm{P} 4$ & c & 909.4 & 6.25 & 229.0 & 1.02 & 0.510 & 6.25 & 229.0 & 1.02 & 0.510 & 1.248 & 45.8 & 1.90 & 0.95 & 9.91 & 3.7 & 36.67 \\
\hline P5 & a & 983.7 & - & - & - & - & 6.89 & 259.1 & 1.13 & 0.565 & 6.647 & 249.9 & 1.19 & 0.60 & 10 & 3.76 & 37.60 \\
\hline \multicolumn{2}{|c|}{ Mean value } & 954.8 & 6.24 & 228.5 & 0.94 & 0.469 & 6.22 & 229.2 & 0.92 & 0.458 & 4.404 & 162.6 & 1.25 & 0.63 & - & - & - \\
\hline \multicolumn{2}{|c|}{$\begin{array}{l}\text { Standard } \\
\text { deviation }\end{array}$} & 43.1 & 0.00 & 0.8 & 0.11 & 0.057 & 0.36 & 15.4 & 0.14 & 0.070 & 2.472 & 91.8 & 0.50 & 0.25 & - & - & - \\
\hline \multicolumn{2}{|c|}{$\begin{array}{c}\text { Relative } \\
\text { deviation [\%] }\end{array}$} & 4.52 & 0.06 & 0.35 & 12.11 & 12.11 & 5.80 & 6.71 & 15.19 & 15.19 & 56.13 & 56.48 & 39.55 & 39.55 & - & - & - \\
\hline
\end{tabular}

Table A35. Results of the tensile tests of P_W,PS.

\begin{tabular}{|c|c|c|c|c|c|c|c|c|c|c|c|c|c|}
\hline $\begin{array}{l}\text { Sample } \\
\text { Number }\end{array}$ & $\begin{array}{l}\text { Curve } \\
\text { Type }\end{array}$ & $\begin{array}{c}E_{t} \\
(\mathrm{MPa})\end{array}$ & $\begin{array}{c}\mathrm{s}_{\mathrm{m}} \\
(\mathrm{MPa})\end{array}$ & $\begin{array}{l}F_{M} \\
(\mathbf{N})\end{array}$ & $\begin{array}{l}e_{m} \\
(\%)\end{array}$ & $\begin{array}{c}e_{M} \\
(\mathrm{~mm})\end{array}$ & $\begin{array}{c}\mathrm{s}_{\mathrm{b}} \\
(\mathrm{MPa})\end{array}$ & $\begin{array}{l}\mathrm{s}_{\mathrm{B}} \\
(\mathrm{N})\end{array}$ & $\begin{array}{c}e_{b} \\
(\%)\end{array}$ & $\begin{array}{c}\mathbf{e}_{\mathrm{B}} \\
(\mathrm{mm})\end{array}$ & $\begin{array}{c}\mathrm{b} \\
(\mathrm{mm})\end{array}$ & $\begin{array}{c}\mathrm{h} \\
(\mathrm{mm})\end{array}$ & $\begin{array}{c}\mathbf{A}_{0} \\
\left(\mathrm{~mm}^{2}\right)\end{array}$ \\
\hline P1 & $\mathrm{a}$ & 2265.6 & 12.65 & 483.4 & 0.64 & 0.318 & 12.545 & 479.2 & 0.64 & 0.32 & 10 & 3.82 & 38.20 \\
\hline $\mathrm{P} 2$ & $\mathrm{a}$ & 2336.9 & 13.34 & 511.0 & 0.69 & 0.346 & 12.800 & 490.4 & 0.72 & 0.36 & 10.03 & 3.82 & 38.31 \\
\hline P3 & $\mathrm{a}$ & 2309.6 & 14.40 & 547.8 & 0.74 & 0.370 & 14.402 & 547.8 & 0.74 & 0.37 & 10.01 & 3.8 & 38.04 \\
\hline $\mathrm{P} 4$ & $\mathrm{a}$ & 2244.1 & 13.65 & 527.9 & 0.69 & 0.343 & 13.436 & 519.6 & 0.68 & 0.34 & 10.07 & 3.84 & 38.67 \\
\hline P5 & $\mathrm{a}$ & 2267.7 & 14.25 & 559.5 & 0.78 & 0.391 & 14.246 & 559.5 & 0.78 & 0.39 & 10.2 & 3.85 & 39.27 \\
\hline P6 & $\mathrm{a}$ & 2379.6 & 13.81 & 536.7 & 0.65 & 0.323 & 13.785 & 535.5 & 0.65 & 0.32 & 10.09 & 3.85 & 38.85 \\
\hline \multicolumn{2}{|c|}{ Mean value } & 2300.6 & 13.68 & 527.7 & 0.70 & 0.348 & 13.536 & 522.0 & 0.70 & 0.35 & - & - & - \\
\hline \multicolumn{2}{|c|}{ Standard deviation } & 51.3 & 0.64 & 27.3 & 0.06 & 0.028 & 0.755 & 31.9 & 0.06 & 0.03 & - & - & - \\
\hline \multicolumn{2}{|c|}{ Relative deviation [\%] } & 2.23 & 4.66 & 5.18 & 8.05 & 8.05 & 5.58 & 6.11 & 8.04 & 8.04 & - & - & - \\
\hline
\end{tabular}


Table A36. Results of the tensile tests of P_C,PS.

\begin{tabular}{|c|c|c|c|c|c|c|c|c|c|c|c|c|c|}
\hline $\begin{array}{c}\text { Sample } \\
\text { Number }\end{array}$ & $\begin{array}{l}\text { Curve } \\
\text { Type }\end{array}$ & $\begin{array}{c}\mathrm{E}_{\mathrm{t}} \\
(\mathrm{MPa})\end{array}$ & $\begin{array}{c}\mathrm{s}_{\mathrm{m}} \\
(\mathrm{MPa})\end{array}$ & $\begin{array}{l}\mathbf{F}_{M} \\
(\mathrm{~N})\end{array}$ & $\begin{array}{l}e_{m} \\
(\%)\end{array}$ & $\underset{(\mathrm{mm})}{\mathbf{e}_{M}}$ & $\begin{array}{c}\mathrm{s}_{\mathrm{b}} \\
(\mathrm{MPa})\end{array}$ & $\begin{array}{c}S_{B} \\
(N)\end{array}$ & $\begin{array}{l}e_{b} \\
(\%)\end{array}$ & $\underset{(\mathrm{mm})}{\mathrm{e}_{\mathrm{B}}}$ & $\begin{array}{c}\mathbf{b} \\
(\mathrm{mm})\end{array}$ & $\underset{(\mathrm{mm})}{\mathrm{h}}$ & $\begin{array}{c}\mathbf{A}_{0} \\
\left(\mathbf{m m}^{2}\right)\end{array}$ \\
\hline P1 & a & 2453.1 & 19.15 & 771.9 & 0.95 & 0.474 & 18.830 & 759.1 & 1.03 & 0.51 & 10.18 & 3.96 & 40.31 \\
\hline P2 & $\mathrm{a}$ & 2438.1 & 19.44 & 773.0 & 0.96 & 0.480 & 19.041 & 757.2 & 1.08 & 0.54 & 10.17 & 3.91 & 39.76 \\
\hline P3 & $\mathrm{a}$ & 2374.3 & 19.21 & 786.4 & 0.95 & 0.474 & 17.708 & 725.1 & 1.19 & 0.59 & 10.16 & 4.03 & 40.94 \\
\hline $\mathrm{P} 4$ & a & 2351.4 & 18.78 & 769.8 & 0.90 & 0.451 & 18.776 & 769.8 & 0.90 & 0.45 & 10.25 & 4 & 41.00 \\
\hline P5 & $\mathrm{a}$ & 2446.2 & 19.51 & 782.2 & 0.93 & 0.467 & 19.461 & 780.2 & 0.95 & 0.48 & 10.15 & 3.95 & 40.09 \\
\hline P6 & $\mathrm{a}$ & 2363.5 & 18.75 & 755.2 & 0.86 & 0.429 & 18.751 & 755.2 & 0.86 & 0.43 & 10.17 & 3.96 & 40.27 \\
\hline \multicolumn{2}{|c|}{ Mean value } & 2404.4 & 19.14 & 773.1 & 0.92 & 0.462 & 18.761 & 757.8 & 1.00 & 0.50 & - & - & - \\
\hline \multicolumn{2}{|c|}{ Standard deviation } & 46.1 & 0.32 & 10.9 & 0.04 & 0.019 & 0.580 & 18.6 & 0.12 & 0.06 & - & - & - \\
\hline \multicolumn{2}{|c|}{ Relative deviation [\%] } & 1.92 & 1.67 & 1.41 & 4.12 & 4.12 & 3.09 & 2.45 & 12.23 & 12.23 & - & - & - \\
\hline
\end{tabular}

Table A37. Results of the tensile tests of $P_{-} W, C, P S$.

\begin{tabular}{|c|c|c|c|c|c|c|c|c|c|c|c|c|c|}
\hline $\begin{array}{c}\text { Sample } \\
\text { Number }\end{array}$ & $\begin{array}{l}\text { Curve } \\
\text { Type }\end{array}$ & $\begin{array}{c}\mathrm{E}_{\mathrm{t}} \\
(\mathrm{MPa})\end{array}$ & $\begin{array}{c}\mathrm{s}_{\mathrm{m}} \\
(\mathrm{MPa})\end{array}$ & $\begin{array}{l}F_{M} \\
(\mathbf{N})\end{array}$ & $\begin{array}{l}e_{m} \\
(\%)\end{array}$ & $\underset{(\mathrm{mm})}{\mathbf{e}_{\mathrm{M}}}$ & $\begin{array}{c}\mathrm{s}_{\mathrm{b}} \\
(\mathrm{MPa})\end{array}$ & $\begin{array}{l}\mathrm{s}_{\mathbf{B}} \\
(\mathrm{N})\end{array}$ & $\begin{array}{l}e_{b} \\
(\%)\end{array}$ & $\begin{array}{c}\mathrm{e}_{\mathrm{B}} \\
(\mathrm{mm})\end{array}$ & $\begin{array}{c}\mathbf{b} \\
(\mathrm{mm})\end{array}$ & $\underset{(\mathrm{mm})}{\mathrm{h}}$ & $\begin{array}{c}\mathbf{A}_{0} \\
\left(\mathrm{~mm}^{2}\right)\end{array}$ \\
\hline P1 & a & 930.4 & 6.80 & 248.6 & 0.86 & 0.432 & 6.729 & 245.9 & 0.87 & 0.43 & 9.85 & 3.71 & 36.54 \\
\hline $\mathrm{P} 2$ & a & 923.3 & 7.33 & 266.0 & 1.04 & 0.519 & 6.714 & 243.8 & 1.09 & 0.55 & 9.84 & 3.69 & 36.31 \\
\hline P3 & $\mathrm{a}$ & 936.5 & 5.46 & 196.1 & 0.67 & 0.334 & 4.349 & 156.1 & 0.64 & 0.32 & 9.78 & 3.67 & 35.89 \\
\hline $\mathrm{P} 4$ & $\mathrm{a}$ & 896.6 & 6.33 & 227.0 & 0.85 & 0.425 & 6.333 & 227.0 & 0.85 & 0.42 & 9.82 & 3.65 & 35.84 \\
\hline P5 & $\mathrm{a}$ & 945.8 & 6.12 & 222.7 & 0.76 & 0.381 & 6.119 & 222.7 & 0.76 & 0.38 & 9.89 & 3.68 & 36.40 \\
\hline P6 & $\mathrm{a}$ & 904.8 & 6.38 & 229.3 & 0.88 & 0.438 & 6.378 & 229.3 & 0.88 & 0.44 & 9.85 & 3.65 & 35.95 \\
\hline \multicolumn{2}{|c|}{ Mean value } & 922.9 & 6.40 & 231.6 & 0.84 & 0.422 & 6.104 & 220.8 & 0.85 & 0.42 & - & - & - \\
\hline \multicolumn{2}{|c|}{ Standard deviation } & 18.9 & 0.63 & 23.8 & 0.12 & 0.062 & 0.891 & 33.0 & 0.15 & 0.08 & - & - & - \\
\hline \multicolumn{2}{|c|}{ Relative deviation [\%] } & 2.05 & 9.83 & 10.28 & 14.71 & 14.71 & 14.60 & 14.96 & 17.72 & 17.72 & - & - & - \\
\hline
\end{tabular}


Table A38. Results of the tensile tests of PO_A.

\begin{tabular}{|c|c|c|c|c|c|c|c|c|c|c|c|c|c|}
\hline $\begin{array}{l}\text { Sample } \\
\text { Number }\end{array}$ & $\begin{array}{l}\text { Curve } \\
\text { Type }\end{array}$ & $\begin{array}{c}E_{t} \\
(\mathrm{MPa})\end{array}$ & $\begin{array}{c}\mathrm{s}_{\mathrm{m}} \\
(\mathrm{MPa})\end{array}$ & $\begin{array}{l}F_{M} \\
(N)\end{array}$ & $\begin{array}{l}e_{m} \\
(\%)\end{array}$ & $\begin{array}{c}e_{M} \\
(\mathrm{~mm})\end{array}$ & $\begin{array}{c}\mathrm{s}_{\mathrm{b}} \\
(\mathrm{MPa})\end{array}$ & $\begin{array}{c}\mathrm{S}_{\mathrm{B}} \\
(\mathrm{N})\end{array}$ & $\begin{array}{c}e_{b} \\
(\%)\end{array}$ & $\begin{array}{c}\mathbf{e}_{B} \\
(\mathrm{~mm})\end{array}$ & $\begin{array}{c}\mathrm{b} \\
(\mathrm{mm})\end{array}$ & $\begin{array}{c}\mathrm{h} \\
(\mathrm{mm})\end{array}$ & $\begin{array}{c}\mathbf{A}_{0} \\
\left(\mathrm{~mm}^{2}\right)\end{array}$ \\
\hline P1 & a & 994.1 & 8.87 & 352.3 & 1.74 & 0.872 & 8.847 & 351.4 & 1.81 & 0.91 & 10.03 & 3.96 & 39.72 \\
\hline $\mathrm{P} 2$ & a & 1043.2 & 9.59 & 360.6 & 1.68 & 0.838 & 8.960 & 337.1 & 1.82 & 0.91 & 10.06 & 3.74 & 37.62 \\
\hline P3 & a & 1113.7 & 9.44 & 356.1 & 1.70 & 0.852 & 9.283 & 350.2 & 1.79 & 0.89 & 9.98 & 3.78 & 37.72 \\
\hline $\mathrm{P} 4$ & a & 1115.3 & 9.50 & 359.0 & 1.47 & 0.733 & 9.368 & 354.0 & 1.50 & 0.75 & 9.97 & 3.79 & 37.79 \\
\hline P5 & a & 986.5 & 9.79 & 371.1 & 1.80 & 0.901 & 9.449 & 358.3 & 1.97 & 0.99 & 9.98 & 3.8 & 37.92 \\
\hline P6 & a & 1066.1 & 9.67 & 361.7 & 1.78 & 0.889 & 9.241 & 345.5 & 1.95 & 0.98 & 9.97 & 3.75 & 37.39 \\
\hline \multicolumn{2}{|c|}{ Mean value } & 1053.2 & 9.48 & 360.2 & 1.70 & 0.848 & 9.191 & 349.4 & 1.81 & 0.90 & - & - & - \\
\hline \multicolumn{2}{|c|}{ Standard deviation } & 56.1 & 0.32 & 6.4 & 0.12 & 0.061 & 0.237 & 7.4 & 0.17 & 0.09 & - & - & - \\
\hline \multicolumn{2}{|c|}{ Relative deviation [\%] } & 5.32 & 3.39 & 1.76 & 7.14 & 7.14 & 2.58 & 2.11 & 9.43 & 9.43 & - & - & - \\
\hline
\end{tabular}

Table A39. Results of the tensile tests of PO_A,W.

\begin{tabular}{|c|c|c|c|c|c|c|c|c|c|c|c|c|c|}
\hline $\begin{array}{l}\text { Sample } \\
\text { Number }\end{array}$ & $\begin{array}{l}\text { Curve } \\
\text { Type }\end{array}$ & $\begin{array}{c}\mathrm{E}_{\mathrm{t}} \\
(\mathrm{MPa})\end{array}$ & $\begin{array}{c}\mathrm{s}_{\mathrm{m}} \\
(\mathrm{MPa})\end{array}$ & $\begin{array}{l}F_{M} \\
(N)\end{array}$ & $\begin{array}{l}\mathbf{e}_{\mathrm{m}} \\
(\%)\end{array}$ & $\underset{(\mathrm{mm})}{\mathbf{e}_{\mathbf{M}}}$ & $\begin{array}{c}\mathrm{s}_{\mathrm{b}} \\
(\mathrm{MPa})\end{array}$ & $\begin{array}{l}\mathrm{s}_{\mathrm{B}} \\
(\mathrm{N})\end{array}$ & $\begin{array}{l}e_{b} \\
(\%)\end{array}$ & $\underset{(\mathrm{mm})}{\mathbf{e}_{\mathbf{B}}}$ & $\begin{array}{c}\mathbf{b} \\
(\mathrm{mm})\end{array}$ & $\begin{array}{c}\mathrm{h} \\
(\mathrm{mm})\end{array}$ & $\begin{array}{c}\mathbf{A}_{0} \\
\left(\mathrm{~mm}^{2}\right)\end{array}$ \\
\hline $\mathrm{P} 1$ & a & 845.8 & 9.29 & 341.8 & 2.19 & 1.096 & 8.707 & 320.4 & & & 9.92 & 3.71 & 36.80 \\
\hline $\mathrm{P} 2$ & a & 896.9 & 10.07 & 358.5 & 2.66 & 1.331 & 9.856 & 351.0 & 2.83 & 1.41 & 9.92 & 3.59 & 35.61 \\
\hline P3 & a & 855.9 & 9.77 & 350.7 & 2.11 & 1.054 & 9.581 & 343.9 & 2.17 & 1.09 & 9.97 & 3.6 & 35.89 \\
\hline $\mathrm{P} 4$ & a & 908.6 & 9.98 & 358.3 & 2.54 & 1.268 & 9.763 & 350.4 & 2.76 & 1.38 & 9.97 & 3.6 & 35.89 \\
\hline P5 & a & 905.5 & 9.55 & 342.7 & 1.87 & 0.934 & 9.289 & 333.1 & 1.99 & 0.99 & 9.99 & 3.59 & 35.86 \\
\hline P6 & a & 860.9 & 8.95 & 325.2 & 2.04 & 1.018 & 8.746 & 317.7 & 2.20 & 1.10 & 9.98 & 3.64 & 36.33 \\
\hline \multicolumn{2}{|c|}{ Mean value } & 878.9 & 9.60 & 346.2 & 2.23 & 1.117 & 9.324 & 336.1 & 2.39 & 1.19 & - & - & - \\
\hline \multicolumn{2}{|c|}{ Standard deviation } & 27.8 & 0.43 & 12.5 & 0.31 & 0.153 & 0.502 & 14.7 & 0.38 & 0.19 & - & - & - \\
\hline \multicolumn{2}{|c|}{ Relative deviation [\%] } & 3.16 & 4.44 & 3.62 & 13.65 & 13.65 & 5.38 & 4.37 & 15.86 & 15.86 & - & - & - \\
\hline
\end{tabular}


Table A40. Results of the tensile tests of PO_A,C.

\begin{tabular}{|c|c|c|c|c|c|c|c|c|c|c|c|c|c|}
\hline $\begin{array}{l}\text { Sample } \\
\text { Number }\end{array}$ & $\begin{array}{l}\text { Curve } \\
\text { Type }\end{array}$ & $\begin{array}{c}E_{t} \\
(\mathrm{MPa})\end{array}$ & $\begin{array}{c}\mathrm{s}_{\mathrm{m}} \\
(\mathrm{MPa})\end{array}$ & $\begin{array}{l}F_{M} \\
(N)\end{array}$ & $\begin{array}{l}e_{m} \\
(\%)\end{array}$ & $\underset{(\mathrm{mm})}{\mathrm{e}_{\mathrm{M}}}$ & $\begin{array}{c}\mathrm{s}_{\mathrm{b}} \\
(\mathrm{MPa})\end{array}$ & $\begin{array}{c}\mathrm{s}_{\mathrm{B}} \\
(\mathrm{N})\end{array}$ & $\begin{array}{c}e_{b} \\
(\%)\end{array}$ & $\begin{array}{c}\mathrm{e}_{\mathrm{B}} \\
(\mathrm{mm})\end{array}$ & $\begin{array}{c}b \\
(\mathrm{~mm})\end{array}$ & $\begin{array}{c}\mathrm{h} \\
(\mathrm{mm})\end{array}$ & $\begin{array}{c}\mathrm{A}_{0} \\
\left(\mathrm{~mm}^{2}\right)\end{array}$ \\
\hline $\mathrm{P} 1$ & a & 1037.3 & 10.16 & 350.1 & 1.96 & 0.980 & 10.158 & 350.1 & 1.96 & 0.98 & 9.82 & 3.51 & 34.47 \\
\hline P2 & a & 920.6 & 8.65 & 306.6 & 1.43 & 0.713 & 8.555 & 303.2 & 1.42 & 0.71 & 9.9 & 3.58 & 35.44 \\
\hline P3 & a & 835.9 & 9.37 & 344.9 & 2.06 & 1.029 & 9.366 & 344.9 & 2.06 & 1.03 & 9.82 & 3.75 & 36.83 \\
\hline P4 & $\mathrm{a}$ & 873.2 & 9.16 & 322.3 & 1.56 & 0.779 & 9.161 & 322.3 & 1.56 & 0.78 & 9.8 & 3.59 & 35.18 \\
\hline P5 & a & 825.4 & 7.34 & 258.4 & 1.11 & 0.556 & 7.224 & 254.3 & 1.12 & 0.56 & 9.78 & 3.6 & 35.21 \\
\hline P6 & a & 840.7 & 8.70 & 307.7 & 1.52 & 0.760 & 8.541 & 302.0 & 1.53 & 0.77 & 9.85 & 3.59 & 35.36 \\
\hline \multicolumn{2}{|c|}{ Mean value } & 888.9 & 8.90 & 315.0 & 1.61 & 0.803 & 8.834 & 312.8 & 1.61 & 0.80 & - & - & - \\
\hline \multicolumn{2}{|c|}{ Standard deviation } & 80.5 & 0.94 & 33.2 & 0.35 & 0.175 & 0.990 & 35.1 & 0.35 & 0.17 & - & - & - \\
\hline \multicolumn{2}{|c|}{ Relative deviation [\%] } & 9.06 & 10.55 & 10.54 & 21.85 & 21.85 & 11.21 & 11.20 & 21.68 & 21.68 & - & - & - \\
\hline
\end{tabular}

Table A41. Results of the tensile tests of PO_A,W,C.

\begin{tabular}{|c|c|c|c|c|c|c|c|c|c|c|c|c|c|}
\hline $\begin{array}{c}\text { Sample } \\
\text { Number }\end{array}$ & $\begin{array}{l}\text { Curve } \\
\text { Type }\end{array}$ & $\begin{array}{c}\mathrm{E}_{\mathrm{t}} \\
(\mathrm{MPa})\end{array}$ & $\begin{array}{c}\mathrm{s}_{\mathrm{m}} \\
(\mathrm{MPa})\end{array}$ & $\begin{array}{l}\mathbf{F}_{\mathbf{M}} \\
(\mathrm{N})\end{array}$ & $\begin{array}{l}e_{m} \\
(\%)\end{array}$ & $\underset{(\mathrm{mm})}{\mathbf{e}_{\mathrm{M}}}$ & $\begin{array}{c}\mathrm{s}_{\mathrm{b}} \\
(\mathrm{MPa})\end{array}$ & $\begin{array}{l}\mathrm{s}_{\mathbf{B}} \\
(\mathrm{N})\end{array}$ & $\begin{array}{l}e_{b} \\
(\%)\end{array}$ & $\begin{array}{c}\mathrm{e}_{\mathrm{B}} \\
(\mathrm{mm})\end{array}$ & $\begin{array}{c}\mathbf{b} \\
(\mathrm{mm})\end{array}$ & $\underset{(\mathrm{mm})}{\mathrm{h}}$ & $\begin{array}{c}\mathbf{A}_{0} \\
\left(\mathrm{~mm}^{2}\right)\end{array}$ \\
\hline P1 & a & 814.3 & 9.52 & 338.5 & 1.85 & 0.925 & 9.351 & 332.6 & 1.87 & 0.93 & 9.88 & 3.6 & 35.57 \\
\hline $\mathrm{P} 2$ & a & 884.0 & 10.31 & 367.3 & 2.43 & 1.217 & 10.310 & 367.3 & 2.43 & 1.22 & 9.84 & 3.62 & 35.62 \\
\hline P3 & $\mathrm{a}$ & 876.0 & 9.93 & 352.6 & 2.05 & 1.027 & 9.499 & 337.4 & 2.12 & 1.06 & 9.84 & 3.61 & 35.52 \\
\hline $\mathrm{P} 4$ & $\mathrm{a}$ & 860.8 & 10.19 & 364.3 & 2.35 & 1.174 & 10.037 & 358.8 & 2.40 & 1.20 & 9.82 & 3.64 & 35.74 \\
\hline P5 & $\mathrm{a}$ & 855.1 & 9.66 & 343.3 & 1.97 & 0.983 & 9.663 & 343.3 & 1.97 & 0.98 & 9.95 & 3.57 & 35.52 \\
\hline P6 & $\mathrm{a}$ & 840.7 & 9.58 & 338.5 & 2.03 & 1.015 & 9.449 & 333.7 & 2.08 & 1.04 & 9.92 & 3.56 & 35.32 \\
\hline \multicolumn{2}{|c|}{ Mean value } & 855.1 & 9.87 & 350.7 & 2.11 & 1.057 & 9.718 & 345.5 & 2.15 & 1.07 & - & - & - \\
\hline \multicolumn{2}{|c|}{ Standard deviation } & 25.2 & 0.33 & 12.8 & 0.23 & 0.114 & 0.377 & 14.3 & 0.23 & 0.11 & - & - & - \\
\hline \multicolumn{2}{|c|}{ Relative deviation [\%] } & 2.95 & 3.36 & 3.64 & 10.77 & 10.77 & 3.88 & 4.15 & 10.61 & 10.61 & - & - & - \\
\hline
\end{tabular}


Table A42. Results of the tensile tests of PO_B.

\begin{tabular}{|c|c|c|c|c|c|c|c|c|c|c|c|c|c|c|c|c|c|}
\hline $\begin{array}{l}\text { Sample } \\
\text { Number }\end{array}$ & $\begin{array}{l}\text { Curve } \\
\text { Type }\end{array}$ & $\begin{array}{c}\mathrm{E}_{\mathrm{t}} \\
(\mathrm{MPa})\end{array}$ & $\begin{array}{c}\mathrm{sy}_{\mathrm{y}} \\
(\mathrm{MPa})\end{array}$ & $\begin{array}{l}F_{y} \\
(N)\end{array}$ & $\begin{array}{c}e_{y} \\
(\%)\end{array}$ & $\begin{array}{c}\mathbf{e}_{\mathbf{Y}} \\
(\mathrm{mm})\end{array}$ & $\begin{array}{c}\mathrm{s}_{\mathrm{m}} \\
(\mathrm{MPa})\end{array}$ & $\begin{array}{l}\mathrm{s}_{\mathrm{M}} \\
(\mathrm{N})\end{array}$ & $\begin{array}{l}e_{m} \\
(\%)\end{array}$ & $\begin{array}{c}e_{M} \\
(\mathrm{~mm})\end{array}$ & $\begin{array}{c}\mathrm{s}_{\mathrm{b}} \\
(\mathrm{MPa})\end{array}$ & $\begin{array}{l}\mathrm{S}_{\mathrm{B}} \\
(\mathrm{N})\end{array}$ & $\begin{array}{l}e_{b} \\
(\%)\end{array}$ & $\underset{(\mathrm{mm})}{\mathrm{e}_{\mathrm{B}}}$ & $\begin{array}{c}\mathrm{b} \\
(\mathrm{mm})\end{array}$ & $\begin{array}{c}\mathrm{h} \\
(\mathrm{mm})\end{array}$ & $\begin{array}{c}\mathrm{A}_{0} \\
\left(\mathrm{~mm}^{2}\right)\end{array}$ \\
\hline P1 & c & 830.6 & - & - & - & - & 9.47 & 332.6 & 1.85 & 0.925 & 9.368 & 329.0 & 1.86 & 0.93 & 10.15 & 3.46 & 35.12 \\
\hline P2 & c & 830.7 & - & - & - & - & 10.35 & 384.5 & 2.52 & 1.260 & 10.120 & 375.8 & 2.67 & 1.34 & 10.2 & 3.64 & 37.13 \\
\hline P3 & c & 877.0 & - & - & - & - & 9.48 & 333.7 & 1.81 & 0.903 & 9.302 & 327.6 & 1.85 & 0.92 & 10.18 & 3.46 & 35.22 \\
\hline $\mathrm{P} 4$ & c & 837.6 & - & - & - & - & 9.35 & 338.8 & 1.82 & 0.910 & 9.174 & 332.5 & 1.85 & 0.93 & 10.21 & 3.55 & 36.25 \\
\hline P5 & c & 847.8 & 10.21 & 369.3 & 2.53 & 1.263 & 10.21 & 369.3 & 2.53 & 1.263 & 7.597 & 274.7 & 3.20 & 1.60 & 10.3 & 3.51 & 36.15 \\
\hline P6 & c & 904.5 & - & - & - & - & 9.47 & 350.5 & 1.58 & 0.788 & 9.347 & 345.9 & 1.62 & 0.81 & 10.25 & 3.61 & 37.00 \\
\hline \multicolumn{2}{|c|}{ Mean value } & 854.7 & 10.21 & 369.3 & 2.53 & 1.263 & 9.72 & 351.6 & 2.02 & 1.008 & 9.151 & 330.9 & 2.18 & 1.09 & - & - & - \\
\hline \multicolumn{2}{|c|}{$\begin{array}{l}\text { Standard } \\
\text { deviation }\end{array}$} & 29.9 & - & - & - & - & 0.44 & 21.2 & 0.40 & 0.202 & 0.832 & 32.9 & 0.62 & 0.31 & - & - & - \\
\hline \multicolumn{2}{|c|}{$\begin{array}{c}\text { Relative } \\
\text { deviation [\%] }\end{array}$} & 3.50 & - & - & - & - & 4.53 & 6.02 & 20.05 & 20.05 & 9.09 & 9.95 & 28.47 & 28.47 & - & - & - \\
\hline
\end{tabular}

Table A43. Results of the tensile tests of PO_B,C.

\begin{tabular}{|c|c|c|c|c|c|c|c|c|c|c|c|c|c|c|c|c|c|}
\hline $\begin{array}{c}\text { Sample } \\
\text { Num- } \\
\text { ber }\end{array}$ & $\begin{array}{l}\text { Curve } \\
\text { Type }\end{array}$ & $\begin{array}{c}E_{t} \\
(\mathrm{MPa})\end{array}$ & $\begin{array}{c}\mathrm{s}_{\mathrm{y}} \\
(\mathrm{MPa})\end{array}$ & $\begin{array}{l}F_{y} \\
(N)\end{array}$ & $\begin{array}{c}e_{y} \\
(\%)\end{array}$ & $\begin{array}{c}e_{Y} \\
(\mathrm{~mm})\end{array}$ & $\begin{array}{c}\mathrm{s}_{\mathrm{m}} \\
(\mathrm{MPa})\end{array}$ & $\begin{array}{l}\mathrm{s}_{\mathrm{M}} \\
(\mathrm{N})\end{array}$ & $\begin{array}{c}e_{m} \\
(\%)\end{array}$ & $\begin{array}{c}e_{M} \\
(\mathrm{~mm})\end{array}$ & $\begin{array}{c}\mathrm{s}_{\mathrm{b}} \\
(\mathrm{MPa})\end{array}$ & $\begin{array}{l}\mathbf{s}_{\mathbf{B}} \\
(\mathrm{N})\end{array}$ & $\begin{array}{c}e_{b} \\
(\%)\end{array}$ & $\begin{array}{c}\mathbf{e}_{B} \\
(\mathrm{~mm})\end{array}$ & $\begin{array}{c}\mathrm{b} \\
(\mathrm{mm})\end{array}$ & $\begin{array}{c}\mathrm{h} \\
(\mathrm{mm})\end{array}$ & $\begin{array}{c}\mathrm{A}_{0} \\
\left(\mathrm{~mm}^{2}\right)\end{array}$ \\
\hline P1 & a & 836.5 & - & - & - & - & 12.51 & 435.6 & 3.64 & 1.818 & 12.512 & 435.6 & 3.64 & 1.82 & 9.89 & 3.52 & 34.81 \\
\hline P2 & a & 845.2 & - & - & - & - & 11.75 & 415.5 & 2.79 & 1.393 & 11.689 & 413.3 & 2.82 & 1.41 & 9.96 & 3.55 & 35.36 \\
\hline P3 & $\mathrm{a}$ & 845.3 & - & - & - & - & 12.43 & 428.7 & 3.20 & 1.600 & 12.178 & 419.9 & 3.34 & 1.67 & 9.88 & 3.49 & 34.48 \\
\hline P4 & c & 864.0 & 12.92 & 447.9 & 3.66 & 1.829 & 12.92 & 447.9 & 3.66 & 1.829 & 12.453 & 431.8 & 4.27 & 2.13 & 9.85 & 3.52 & 34.67 \\
\hline P5 & a & 814.7 & - & - & - & - & 11.07 & 384.1 & 2.23 & 1.113 & 11.066 & 384.1 & 2.23 & 1.11 & 9.86 & 3.52 & 34.71 \\
\hline \multicolumn{2}{|c|}{ Mean value } & 846.0 & 12.92 & 447.9 & 3.66 & 1.829 & 12.17 & 424.0 & 3.13 & 1.565 & 11.990 & 417.7 & 3.27 & 1.64 & - & - & - \\
\hline \multicolumn{2}{|c|}{$\begin{array}{l}\text { Standard } \\
\text { deviation }\end{array}$} & 20.0 & - & - & - & - & 0.66 & 22.2 & 0.55 & 0.273 & 0.542 & 18.4 & 0.70 & 0.35 & - & - & - \\
\hline \multicolumn{2}{|c|}{$\begin{array}{c}\text { Relative } \\
\text { deviation [\%] }\end{array}$} & 2.36 & - & - & - & - & 5.42 & 5.24 & 17.48 & 17.48 & 4.52 & 4.40 & 21.31 & 21.31 & - & - & - \\
\hline
\end{tabular}


Table A44. Results of the tensile tests of P.

\begin{tabular}{|c|c|c|c|c|c|c|c|c|c|c|c|c|c|c|c|c|c|}
\hline $\begin{array}{l}\text { Sample } \\
\text { Number }\end{array}$ & $\begin{array}{l}\text { Curve } \\
\text { Type }\end{array}$ & $\begin{array}{c}\mathrm{E}_{\mathrm{t}} \\
(\mathrm{MPa})\end{array}$ & $\begin{array}{c}\mathrm{s}_{\mathrm{y}} \\
(\mathrm{MPa})\end{array}$ & $\begin{array}{l}F_{y} \\
(N)\end{array}$ & $\begin{array}{l}e_{y} \\
(\%)\end{array}$ & $\begin{array}{c}e_{Y} \\
(\mathrm{~mm})\end{array}$ & $\begin{array}{c}\mathrm{s}_{\mathrm{m}} \\
(\mathrm{MPa})\end{array}$ & $\begin{array}{l}\mathrm{s}_{\mathrm{M}} \\
(\mathrm{N})\end{array}$ & $\begin{array}{l}e_{m} \\
(\%)\end{array}$ & $\underset{(\mathrm{mm})}{\mathrm{e}_{\mathrm{M}}}$ & $\begin{array}{c}\mathrm{s}_{\mathrm{b}} \\
(\mathrm{MPa})\end{array}$ & $\begin{array}{l}\mathrm{S}_{\mathrm{B}} \\
(\mathrm{N})\end{array}$ & $\begin{array}{c}e_{b} \\
(\%)\end{array}$ & $\underset{(\mathrm{mm})}{\mathbf{e}_{\mathbf{B}}}$ & $\begin{array}{c}\mathrm{b} \\
(\mathrm{mm})\end{array}$ & $\begin{array}{c}\mathrm{h} \\
(\mathrm{mm})\end{array}$ & $\begin{array}{c}\mathrm{A}_{0} \\
\left(\mathrm{~mm}^{2}\right)\end{array}$ \\
\hline P1 & a & 924.8 & - & - & - & - & 5.83 & 216.3 & 0.78 & 0.391 & 5.664 & 210.1 & 0.79 & 0.40 & 10 & 3.71 & 37.10 \\
\hline $\mathrm{P} 2$ & a & 914.5 & - & - & - & - & 6.01 & 223.4 & 0.93 & 0.464 & 5.663 & 210.3 & 1.01 & 0.50 & 10.01 & 3.71 & 37.14 \\
\hline P3 & c & 1005.8 & 6.24 & 227.9 & 0.86 & 0.429 & 6.24 & 227.9 & 0.86 & 0.429 & 1.246 & 45.5 & 1.82 & 0.91 & 9.95 & 3.67 & 36.52 \\
\hline P4 & c & 909.4 & 6.25 & 229.0 & 1.02 & 0.510 & 6.25 & 229.0 & 1.02 & 0.510 & 1.248 & 45.8 & 1.90 & 0.95 & 9.91 & 3.7 & 36.67 \\
\hline P5 & c & 983.7 & - & - & - & - & 6.89 & 259.1 & 1.13 & 0.565 & 6.647 & 249.9 & 1.19 & 0.60 & 10 & 3.76 & 37.60 \\
\hline P6 & a & 990.5 & - & - & - & - & 6.12 & 219.6 & 0.78 & 0.389 & 5.959 & 213.8 & 0.80 & 0.40 & 9.91 & 3.62 & 35.87 \\
\hline \multicolumn{2}{|c|}{ Mean value } & 954.8 & 6.24 & 228.5 & 0.94 & 0.469 & 6.22 & 229.2 & 0.92 & 0.458 & 4.404 & 162.6 & 1.25 & 0.63 & - & - & - \\
\hline \multicolumn{2}{|c|}{$\begin{array}{l}\text { Standard } \\
\text { deviation }\end{array}$} & 43.1 & 0.00 & 0.8 & 0.11 & 0.057 & 0.36 & 15.4 & 0.14 & 0.070 & 2.472 & 91.8 & 0.50 & 0.25 & - & - & - \\
\hline \multicolumn{2}{|c|}{$\begin{array}{c}\text { Relative } \\
\text { deviation [\%] }\end{array}$} & 4.52 & 0.06 & 0.35 & 12.11 & 12.11 & 5.80 & 6.71 & 15.19 & 15.19 & 56.13 & 56.48 & 39.55 & 39.55 & - & - & - \\
\hline
\end{tabular}

Table A45. Results of the tensile tests of P_C.

\begin{tabular}{|c|c|c|c|c|c|c|c|c|c|c|c|c|c|}
\hline $\begin{array}{c}\text { Sample } \\
\text { Number }\end{array}$ & $\begin{array}{l}\text { Curve } \\
\text { Type }\end{array}$ & $\begin{array}{c}E_{t} \\
(\mathrm{MPa})\end{array}$ & $\begin{array}{c}\mathrm{s}_{\mathrm{m}} \\
(\mathrm{MPa})\end{array}$ & $\begin{array}{l}F_{M} \\
(\mathbf{N})\end{array}$ & $\begin{array}{l}e_{m} \\
(\%)\end{array}$ & $\begin{array}{c}e_{M} \\
(\mathrm{~mm})\end{array}$ & $\begin{array}{c}\mathrm{s}_{\mathrm{b}} \\
(\mathrm{MPa})\end{array}$ & $\begin{array}{l}\mathrm{s}_{\mathrm{B}} \\
(\mathrm{N})\end{array}$ & $\begin{array}{c}e_{b} \\
(\%)\end{array}$ & $\begin{array}{c}\mathrm{e}_{\mathrm{B}} \\
(\mathrm{mm})\end{array}$ & $\begin{array}{c}\mathrm{b} \\
(\mathrm{mm})\end{array}$ & $\begin{array}{c}\mathrm{h} \\
(\mathrm{mm})\end{array}$ & $\begin{array}{c}\mathbf{A}_{0} \\
\left(\mathrm{~mm}^{2}\right)\end{array}$ \\
\hline P1 & $\mathrm{a}$ & 930.4 & 6.80 & 248.6 & 0.86 & 0.432 & 6.803 & 248.6 & 0.86 & 0.43 & 9.85 & 3.71 & 36.54 \\
\hline P2 & $\mathrm{a}$ & 923.3 & 7.33 & 266.0 & 1.04 & 0.519 & 7.327 & 266.0 & 1.04 & 0.52 & 9.84 & 3.69 & 36.31 \\
\hline P3 & $\mathrm{a}$ & 936.5 & 5.46 & 196.1 & 0.67 & 0.334 & 5.465 & 196.1 & 0.67 & 0.33 & 9.78 & 3.67 & 35.89 \\
\hline $\mathrm{P} 4$ & $\mathrm{a}$ & 896.6 & 6.33 & 227.0 & 0.85 & 0.425 & 6.333 & 227.0 & 0.85 & 0.42 & 9.82 & 3.65 & 35.84 \\
\hline P5 & $\mathrm{a}$ & 945.8 & 6.12 & 222.7 & 0.76 & 0.381 & 6.119 & 222.7 & 0.76 & 0.38 & 9.89 & 3.68 & 36.40 \\
\hline P6 & $\mathrm{a}$ & 904.8 & 6.38 & 229.3 & 0.88 & 0.438 & 6.378 & 229.3 & 0.88 & 0.44 & 9.85 & 3.65 & 35.95 \\
\hline \multicolumn{2}{|c|}{ Mean value } & 922.9 & 6.40 & 231.6 & 0.84 & 0.422 & 6.404 & 231.6 & 0.84 & 0.42 & - & - & - \\
\hline \multicolumn{2}{|c|}{ Standard deviation } & 18.9 & 0.63 & 23.8 & 0.12 & 0.062 & 0.629 & 23.8 & 0.12 & 0.06 & - & - & - \\
\hline \multicolumn{2}{|c|}{ Relative deviation [\%] } & 2.05 & 9.83 & 10.28 & 14.71 & 14.71 & 9.83 & 10.28 & 14.71 & 14.71 & - & - & - \\
\hline
\end{tabular}




\section{Appendix G. Bulk Densities}

Table A46. Results of bulk density tests of P_PE; P_C,PE; P_W,PE; and P_W,C,PE.

\begin{tabular}{|c|c|c|c|c|c|c|c|c|}
\hline \multirow{2}{*}{$\begin{array}{c}\text { Material } \\
\text { Sample } \\
\text { Number }\end{array}$} & \multicolumn{2}{|c|}{ P_PE } & \multicolumn{2}{|c|}{ P_C,PE } & \multicolumn{2}{|c|}{ P_W,PE } & \multicolumn{2}{|c|}{ P_W,C,PE } \\
\hline & $\begin{array}{l}\text { Net Mass } \\
\text { (g) }\end{array}$ & $\begin{array}{l}\text { Bulk Density } \\
\left(\mathrm{g} / \mathrm{cm}^{3}\right)\end{array}$ & $\begin{array}{l}\text { Net Mass } \\
\text { (g) }\end{array}$ & $\begin{array}{l}\text { Bulk Density } \\
\qquad\left(\mathrm{g} / \mathrm{cm}^{3}\right)\end{array}$ & $\begin{array}{l}\text { Net Mass } \\
(\mathrm{g})\end{array}$ & $\begin{array}{l}\text { Bulk Density } \\
\qquad\left(\mathrm{g} / \mathrm{cm}^{3}\right)\end{array}$ & $\begin{array}{l}\text { Net Mass } \\
\text { (g) }\end{array}$ & $\begin{array}{c}\text { Bulk Density } \\
\left(\mathrm{g} / \mathrm{cm}^{3}\right)\end{array}$ \\
\hline P1 & 8.486 & 0.0849 & 48.996 & 0.4900 & 7.272 & 0.0727 & 48.983 & 0.4898 \\
\hline $\mathrm{P} 2$ & 8.237 & 0.0824 & 48.538 & 0.4854 & 7.373 & 0.0737 & 48.992 & 0.4899 \\
\hline P3 & 8.178 & 0.0818 & 49.016 & 0.4902 & 7.466 & 0.0747 & 49.069 & 0.4907 \\
\hline $\mathrm{P} 4$ & 8.211 & 0.0821 & 48.050 & 0.4805 & 7.192 & 0.0719 & 50.302 & 0.5030 \\
\hline P5 & 7.854 & 0.0785 & 48.420 & 0.4842 & 6.891 & 0.0689 & 49.531 & 0.4953 \\
\hline
\end{tabular}

Table A47. Results of bulk density tests of P_PP; P_C,PP; P_W,PP; and P_W,C,PP.

\begin{tabular}{|c|c|c|c|c|c|c|c|c|}
\hline \multirow{2}{*}{$\begin{array}{c}\text { Material } \\
\text { Sample } \\
\text { Number }\end{array}$} & \multicolumn{2}{|c|}{ P_PP } & \multicolumn{2}{|c|}{ P_C,PP } & \multicolumn{2}{|c|}{ P_W,PP } & \multicolumn{2}{|c|}{ P_W,C,PP } \\
\hline & $\begin{array}{l}\text { Net Mass } \\
\text { (g) }\end{array}$ & $\begin{array}{c}\text { Bulk Density } \\
\left(\mathrm{g} / \mathrm{cm}^{3}\right)\end{array}$ & $\begin{array}{l}\text { Net Mass } \\
\text { (g) }\end{array}$ & $\begin{array}{c}\text { Bulk Density } \\
\left(\mathrm{g} / \mathrm{cm}^{3}\right)\end{array}$ & $\begin{array}{l}\text { Net Mass } \\
\text { (g) }\end{array}$ & $\begin{array}{c}\text { Bulk Density } \\
\left(\mathrm{g} / \mathrm{cm}^{3}\right)\end{array}$ & $\begin{array}{l}\text { Net Mass } \\
\text { (g) }\end{array}$ & $\begin{array}{l}\text { Bulk Density } \\
\left(\mathrm{g} / \mathrm{cm}^{3}\right)\end{array}$ \\
\hline $\mathrm{P} 1$ & 16.825 & 0.1683 & 43.877 & 0.4388 & 15.463 & 0.1546 & 46.074 & 0.4607 \\
\hline P2 & 16.368 & 0.1637 & 44.926 & 0.4493 & 15.625 & 0.1563 & 47.104 & 0.4710 \\
\hline P3 & 17.537 & 0.1754 & 43.697 & 0.4370 & 15.075 & 0.1508 & 46.296 & 0.4630 \\
\hline $\mathrm{P} 4$ & 15.492 & 0.1549 & 44.057 & 0.4406 & 15.196 & 0.1520 & 47.222 & 0.4722 \\
\hline P5 & 15.415 & 0.1542 & 43.769 & 0.4377 & 14.955 & 0.1496 & 46.712 & 0.4671 \\
\hline
\end{tabular}

Table A48. Results of bulk density tests of P_PS; P_C,PS; P_W,PS; and P_W,C,PS.

\begin{tabular}{|c|c|c|c|c|c|c|c|c|}
\hline \multirow{2}{*}{$\begin{array}{c}\text { Material } \\
\text { Sample } \\
\text { Number }\end{array}$} & \multicolumn{2}{|c|}{ P_PS } & \multicolumn{2}{|c|}{ P_W,PS } & \multicolumn{2}{|c|}{ P_W,PS } & \multicolumn{2}{|c|}{ PS_W,C,PS } \\
\hline & $\begin{array}{l}\text { Net Mass } \\
\text { (g) }\end{array}$ & $\begin{array}{l}\text { Bulk Density } \\
\left(\mathrm{g} / \mathrm{cm}^{3}\right)\end{array}$ & $\begin{array}{l}\text { Net Mass } \\
\text { (g) }\end{array}$ & $\begin{array}{l}\text { Bulk Density } \\
\qquad\left(\mathrm{g} / \mathrm{cm}^{3}\right)\end{array}$ & $\begin{array}{c}\text { Net Mass } \\
\text { (g) }\end{array}$ & $\begin{array}{l}\text { Bulk Density } \\
\qquad\left(\mathrm{g} / \mathrm{cm}^{3}\right)\end{array}$ & $\begin{array}{l}\text { Net Mass } \\
\text { (g) }\end{array}$ & $\begin{array}{l}\text { Bulk Density } \\
\left(\mathrm{g} / \mathrm{cm}^{3}\right)\end{array}$ \\
\hline P1 & 16.986 & 0.1699 & 26.825 & 0.2683 & 16.369 & 0.1637 & 28.51 & 0.2851 \\
\hline $\mathrm{P} 2$ & 16.08 & 0.1608 & 27.184 & 0.2718 & 17.167 & 0.1717 & 28.062 & 0.2806 \\
\hline P3 & 16.506 & 0.1651 & 26.986 & 0.2699 & 14.616 & 0.1462 & 27.355 & 0.2736 \\
\hline $\mathrm{P} 4$ & 15.464 & 0.1546 & 27.859 & 0.2786 & 16.297 & 0.1630 & 27.326 & 0.2733 \\
\hline P5 & 16.216 & 0.1622 & 27.357 & 0.2736 & 14.762 & 0.1476 & 28.576 & 0.2858 \\
\hline
\end{tabular}


Table A49. Results of bulk density tests of PO_A; PO_A,C; PO_A,W; and PO_A,W,C.

\begin{tabular}{|c|c|c|c|c|c|c|c|c|}
\hline \multirow{2}{*}{$\begin{array}{l}\text { Material } \\
\text { Sample } \\
\text { Number }\end{array}$} & \multicolumn{2}{|c|}{ PO_A } & \multicolumn{2}{|c|}{ PO_A,C } & \multicolumn{2}{|c|}{ PO_A,W } & \multicolumn{2}{|c|}{ PO_A,W,C } \\
\hline & $\begin{array}{l}\text { Net Mass } \\
\text { (g) }\end{array}$ & $\begin{array}{l}\text { Bulk Density } \\
\qquad\left(\mathrm{g} / \mathrm{cm}^{3}\right)\end{array}$ & $\begin{array}{l}\text { Net Mass } \\
\text { (g) }\end{array}$ & $\begin{array}{l}\text { Bulk Density } \\
\left(\mathrm{g} / \mathrm{cm}^{3}\right)\end{array}$ & $\begin{array}{l}\text { Net Mass } \\
\text { (g) }\end{array}$ & $\begin{array}{l}\text { Bulk Density } \\
\left(\mathrm{g} / \mathrm{cm}^{3}\right)\end{array}$ & $\begin{array}{l}\text { Net Mass } \\
\text { (g) }\end{array}$ & $\begin{array}{l}\text { Bulk Density } \\
\left(\mathrm{g} / \mathrm{cm}^{3}\right)\end{array}$ \\
\hline $\mathrm{P} 1$ & 6.955 & 0.0696 & 40.454 & 0.4045 & 7.046 & 0.0705 & 46.537 & 0.4654 \\
\hline P2 & 7.202 & 0.0720 & 39.489 & 0.3949 & 6.758 & 0.0676 & 45.656 & 0.4566 \\
\hline P3 & 7.133 & 0.0713 & 40.002 & 0.4000 & 6.483 & 0.0648 & 45.822 & 0.4582 \\
\hline $\mathrm{P} 4$ & 6.671 & 0.0667 & 39.872 & 0.3987 & 6.574 & 0.0657 & 45.478 & 0.4548 \\
\hline P5 & 7.091 & 0.0709 & 40.090 & 0.4009 & 6.640 & 0.0664 & 44.83 & 0.4483 \\
\hline
\end{tabular}

Table A50. Results of bulk density tests of PO_B; PO_B,C; P; and P_C.

\begin{tabular}{|c|c|c|c|c|c|c|c|c|}
\hline \multirow{2}{*}{$\begin{array}{c}\text { Material } \\
\text { Sample } \\
\text { Number }\end{array}$} & \multicolumn{2}{|c|}{ PO_B } & \multicolumn{2}{|c|}{ PO_B,C } & \multicolumn{2}{|c|}{$\mathbf{P}$} & \multicolumn{2}{|c|}{ P_C } \\
\hline & $\begin{array}{l}\text { Net Mass } \\
\text { (g) }\end{array}$ & $\begin{array}{c}\text { Bulk Density } \\
\left(\mathrm{g} / \mathrm{cm}^{3}\right)\end{array}$ & $\begin{array}{l}\text { Net Mass } \\
\text { (g) }\end{array}$ & $\begin{array}{c}\text { Bulk Density } \\
\left(\mathrm{g} / \mathrm{cm}^{3}\right)\end{array}$ & $\begin{array}{l}\text { Net Mass } \\
\text { (g) }\end{array}$ & $\begin{array}{c}\text { Bulk Density } \\
\left(\mathrm{g} / \mathrm{cm}^{3}\right)\end{array}$ & $\begin{array}{l}\text { Net Mass } \\
\text { (g) }\end{array}$ & $\begin{array}{l}\text { Bulk Density } \\
\left(\mathrm{g} / \mathrm{cm}^{3}\right)\end{array}$ \\
\hline P1 & 8.944 & 0.0894 & 47.328 & 0.4733 & 10.362 & 0.1036 & 44.022 & 0.4402 \\
\hline $\mathrm{P} 2$ & 8.805 & 0.0881 & 48.663 & 0.4866 & 11.124 & 0.1112 & 44.705 & 0.4471 \\
\hline P3 & 9.143 & 0.0914 & 48.607 & 0.4861 & 11.679 & 0.1168 & 44.073 & 0.4407 \\
\hline $\mathrm{P} 4$ & 9.586 & 0.0959 & 47.541 & 0.4754 & 12.066 & 0.1207 & 44.469 & 0.4447 \\
\hline P5 & 9.452 & 0.0945 & 47.759 & 0.4776 & 11.326 & 0.1133 & 44.847 & 0.4485 \\
\hline
\end{tabular}

Table A51. Results of bulk density tests of P_PET and P_W,PET.

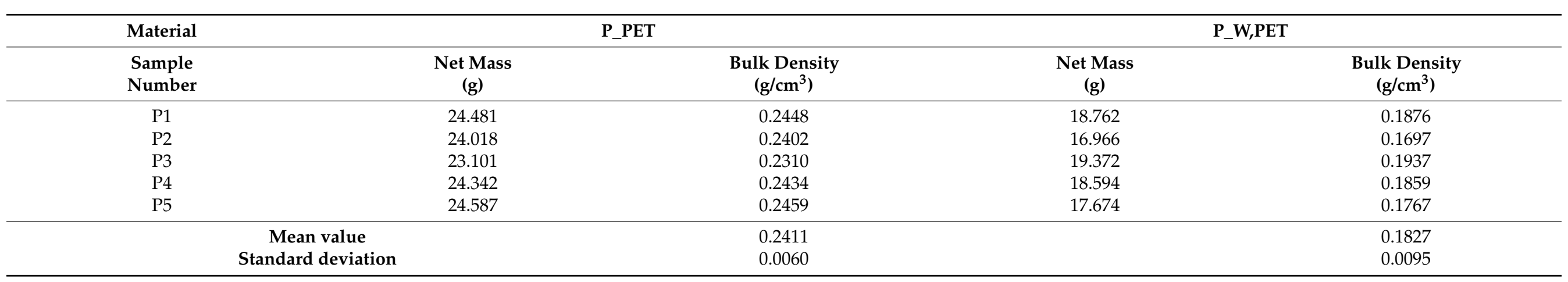


Appendix H. Ash Contents

Table A52. Results of ash content tests of P_PET and P_W,PET.

\begin{tabular}{|c|c|c|c|c|c|c|c|}
\hline $\begin{array}{l}\text { Sample Iden- } \\
\text { tification }\end{array}$ & $\begin{array}{l}\text { Crucible } \\
\text { Empty (g) }\end{array}$ & $\begin{array}{l}\text { Crucible and } \\
\text { Sample } \\
\text { (g) }\end{array}$ & $\begin{array}{c}\text { Crucible } \\
\text { Containing } \\
\text { Ash (g) }\end{array}$ & $\begin{array}{l}\text { Ignition } \\
\text { Residue } \\
\text { (g) }\end{array}$ & $\begin{array}{l}\text { Ash Content } \\
\text { (AC) (\%) }\end{array}$ & $\begin{array}{c}\text { Mean Value } \\
\text { AC (\%) }\end{array}$ & $\begin{array}{c}\text { Relative } \\
\text { Deviation } \\
(\%)\end{array}$ \\
\hline P_PE & 36.81 & 38.90 & 36.89 & 0.086 & 4.08 & & \\
\hline P_PE & 38.59 & 40.46 & 38.67 & 0.081 & 4.32 & 4.40 & 0.37 \\
\hline P_PE & 36.51 & 38.92 & 36.62 & 0.116 & 4.81 & & \\
\hline P_W,PE & 34.33 & 36.30 & 34.37 & 0.046 & 2.31 & & \\
\hline P_W,PE & 38.15 & 40.07 & 38.19 & 0.048 & 2.48 & 2.40 & 0.08 \\
\hline P_W,PE & 33.20 & 34.84 & 33.24 & 0.039 & 2.40 & & \\
\hline P_C,PE & 32.97 & 34.58 & 33.03 & 0.063 & 3.89 & & \\
\hline P_C,PE & 38.04 & 39.99 & 38.12 & 0.080 & 4.09 & 3.93 & 0.14 \\
\hline P_C,PE & 36.40 & 38.01 & 36.46 & 0.061 & 3.81 & & \\
\hline P_W,C,PE & 32.72 & 34.60 & 32.77 & 0.044 & 2.32 & & \\
\hline P_W,C,PE & 39.22 & 40.96 & 39.26 & 0.043 & 2.47 & 2.40 & 0.08 \\
\hline P_W,C,PE & 34.45 & 36.01 & 34.48 & 0.038 & 2.43 & & \\
\hline P_PP & 34.92 & 37.02 & 34.96 & 0.045 & 2.16 & & \\
\hline P_PP & 34.89 & 36.85 & 34.94 & 0.051 & 2.60 & 2.41 & 0.23 \\
\hline P_PP & 35.70 & 38.24 & 35.76 & 0.063 & 2.48 & & \\
\hline P_W,PP & 32.67 & 34.59 & 32.72 & 0.045 & 2.37 & & \\
\hline P_W,PP & 35.33 & 37.33 & 35.39 & 0.060 & 3.00 & 2.39 & 0.59 \\
\hline P_W,PP & 37.50 & 39.66 & 37.53 & 0.040 & 1.82 & & \\
\hline P_C,PP & 34.98 & 37.00 & 35.04 & 0.059 & 2.91 & & \\
\hline P_C,PP & 39.22 & 41.00 & 39.26 & 0.044 & 2.46 & 2.67 & 0.23 \\
\hline P_C,PP & 31.23 & 32.67 & 31.27 & 0.038 & 2.63 & & \\
\hline P_W,C,PP & 34.86 & 36.70 & 34.89 & 0.032 & 1.72 & & \\
\hline P_W,C,PP & 34.98 & 36.63 & 35.01 & 0.026 & 1.57 & 1.68 & 0.10 \\
\hline P_W,C,PP & 35.64 & 37.28 & 35.67 & 0.029 & 1.77 & & \\
\hline P_PS & 39.17 & 41.17 & 39.25 & 0.083 & 4.17 & & \\
\hline P_PS & 32.72 & 34.65 & 32.81 & 0.086 & 4.46 & 4.59 & 0.50 \\
\hline P_PS & 39.48 & 40.96 & 39.55 & 0.076 & 5.14 & & \\
\hline P_W,PS & 33.10 & 35.11 & 33.17 & 0.071 & 3.53 & & \\
\hline P_W,PS & 39.98 & 40.94 & 40.01 & 0.026 & 2.69 & 3.36 & 0.60 \\
\hline P_W,PS & 37.68 & 39.95 & 37.77 & 0.088 & 3.85 & & \\
\hline P_C,PS & 39.48 & 41.24 & 39.56 & 0.088 & 4.97 & & \\
\hline P_C,PS & 39.04 & 41.02 & 39.14 & 0.100 & 5.04 & 4.98 & 0.05 \\
\hline P_C,PS & 31.23 & 33.28 & 31.33 & 0.101 & 4.94 & & \\
\hline P_W,C,PS & 38.81 & 40.94 & 38.88 & 0.078 & 3.63 & & \\
\hline P_W,C,PS & 39.81 & 41.94 & 39.88 & 0.075 & 3.53 & 3.63 & 0.11 \\
\hline P_W,C,PS & 33.64 & 35.25 & 33.70 & 0.060 & 3.74 & & \\
\hline PO_A & 34.55 & 36.60 & 34.67 & 0.127 & 6.18 & & \\
\hline PO_A & 33.56 & 35.43 & 33.68 & 0.118 & 6.32 & 6.25 & 0.07 \\
\hline PO_A & 39.06 & 41.03 & 39.18 & 0.124 & 6.27 & & \\
\hline PO_A,W & 36.39 & 38.37 & 36.47 & 0.082 & 4.13 & & \\
\hline PO_A,W & 34.48 & 36.53 & 34.56 & 0.085 & 4.16 & 4.15 & 0.01 \\
\hline PO_A,W & 32.13 & 34.51 & 32.23 & 0.099 & 4.15 & & \\
\hline
\end{tabular}


Table A52. Cont

\begin{tabular}{|c|c|c|c|c|c|c|c|}
\hline $\begin{array}{l}\text { Sample Iden- } \\
\text { tification }\end{array}$ & $\begin{array}{l}\text { Crucible } \\
\text { Empty (g) }\end{array}$ & $\begin{array}{l}\text { Crucible and } \\
\text { Sample } \\
\text { (g) }\end{array}$ & $\begin{array}{c}\text { Crucible } \\
\text { Containing } \\
\text { Ash (g) }\end{array}$ & $\begin{array}{l}\text { Ignition } \\
\text { Residue } \\
\text { (g) }\end{array}$ & $\begin{array}{l}\text { Ash Content } \\
\text { (AC) }(\%)\end{array}$ & $\begin{array}{c}\text { Mean Value } \\
\text { AC (\%) }\end{array}$ & $\begin{array}{c}\text { Relative } \\
\text { Deviation } \\
(\%)\end{array}$ \\
\hline PO_A,C & 33.17 & 35.05 & 33.28 & 0.110 & 5.90 & & \\
\hline PO_A,C & 34.10 & 35.73 & 34.19 & 0.094 & 5.76 & 5.81 & 0.08 \\
\hline PO_A,C & 39.17 & 40.54 & 39.25 & 0.079 & 5.78 & & \\
\hline PO_A,W,C & 37.67 & 39.67 & 37.76 & 0.082 & 4.12 & & \\
\hline PO_A,W,C & 40.03 & 41.28 & 40.08 & 0.050 & 3.96 & 3.92 & 0.21 \\
\hline PO_A,W,C & 33.37 & 34.51 & 33.42 & 0.042 & 3.70 & & \\
\hline PO_B & 38.58 & 40.23 & 38.62 & 0.036 & 2.20 & & \\
\hline PO_B & 33.44 & 35.33 & 33.48 & 0.040 & 2.12 & 2.21 & 0.10 \\
\hline PO_B & 37.67 & 39.87 & 37.72 & 0.051 & 2.31 & & \\
\hline PO_B,C & 39.04 & 40.77 & 39.08 & 0.043 & 2.46 & & \\
\hline PO_B,C & 34.44 & 36.07 & 34.48 & 0.040 & 2.48 & 2.45 & 0.05 \\
\hline PO_B,C & 35.64 & 36.95 & 35.67 & 0.031 & 2.40 & & \\
\hline $\mathrm{P}$ & 33.41 & 35.43 & 33.59 & 0.176 & 8.71 & & \\
\hline $\mathrm{P}$ & 34.53 & 36.85 & 34.72 & 0.184 & 7.95 & 8.41 & 0.41 \\
\hline $\mathrm{P}$ & 33.53 & 36.45 & 33.78 & 0.251 & 8.57 & & \\
\hline P_C & 36.54 & 38.42 & 36.67 & 0.122 & 6.47 & & \\
\hline P_C & 38.43 & 40.20 & 38.54 & 0.115 & 6.48 & 6.19 & 0.51 \\
\hline P_C & 38.59 & 39.76 & 38.66 & 0.065 & 5.60 & & \\
\hline
\end{tabular}

\section{Appendix I. Exemplary Material Photos}

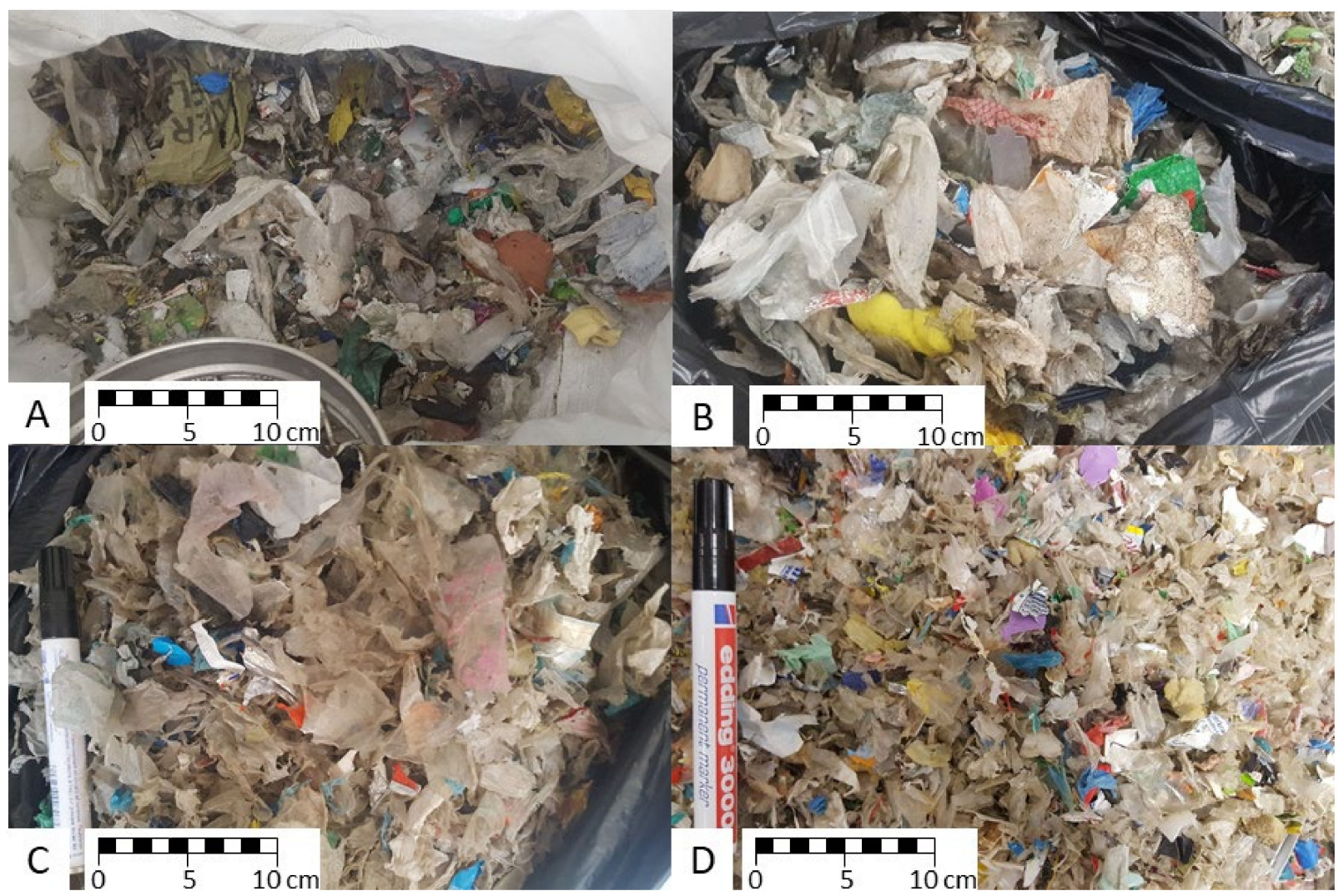

Figure A2. Exemplary photos of the input materials: SRF in (A) and (B), PO_A in (C), and PO_B in (D). 


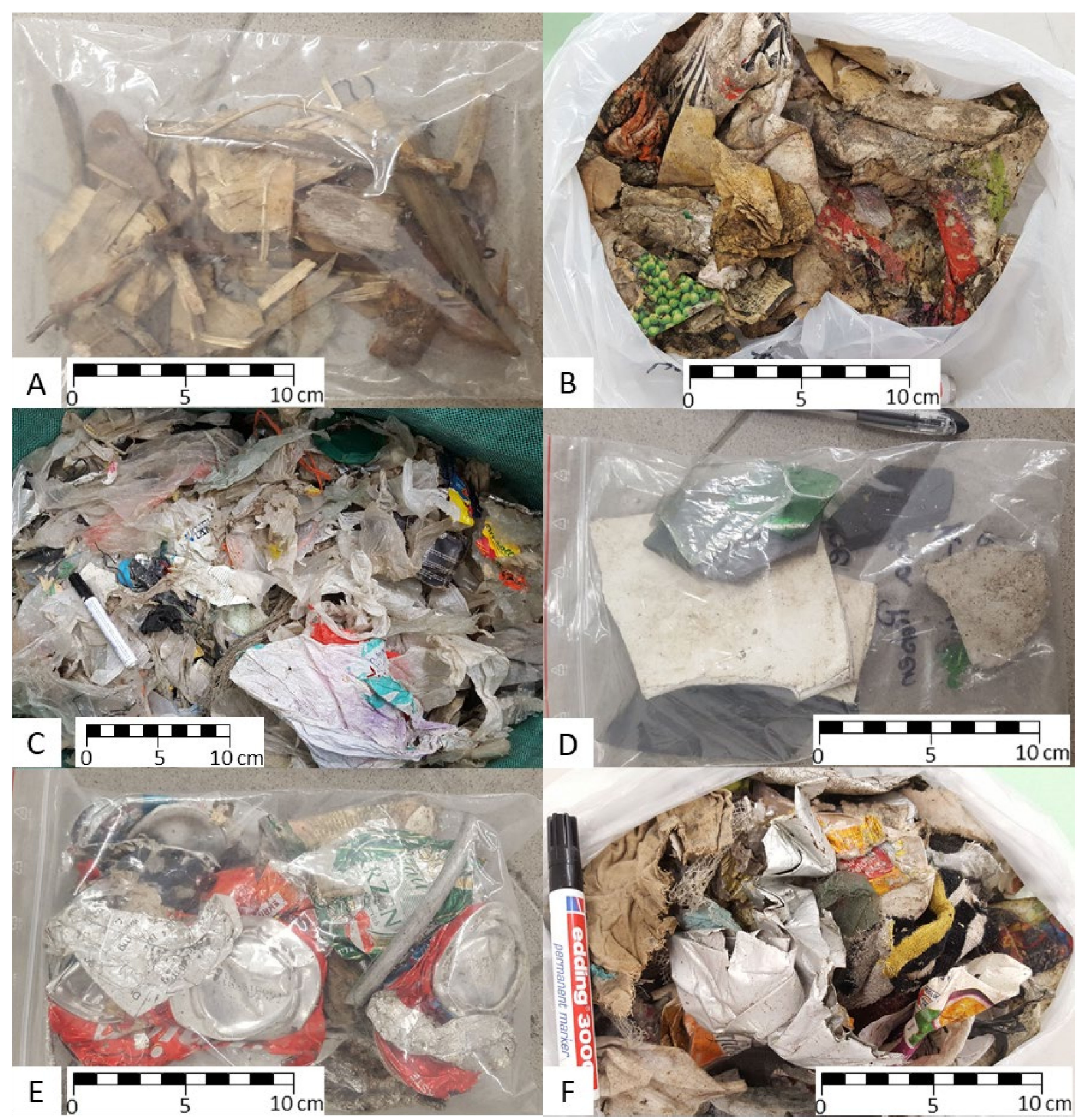

Figure A3. Exemplary photos of the manually sorted material fractions: wood $-\mathbf{A} ;$ P\&C$-\mathbf{B}$; plastics $-\mathbf{C}$; inert $-\mathbf{D}$; metalsE; others-F. 

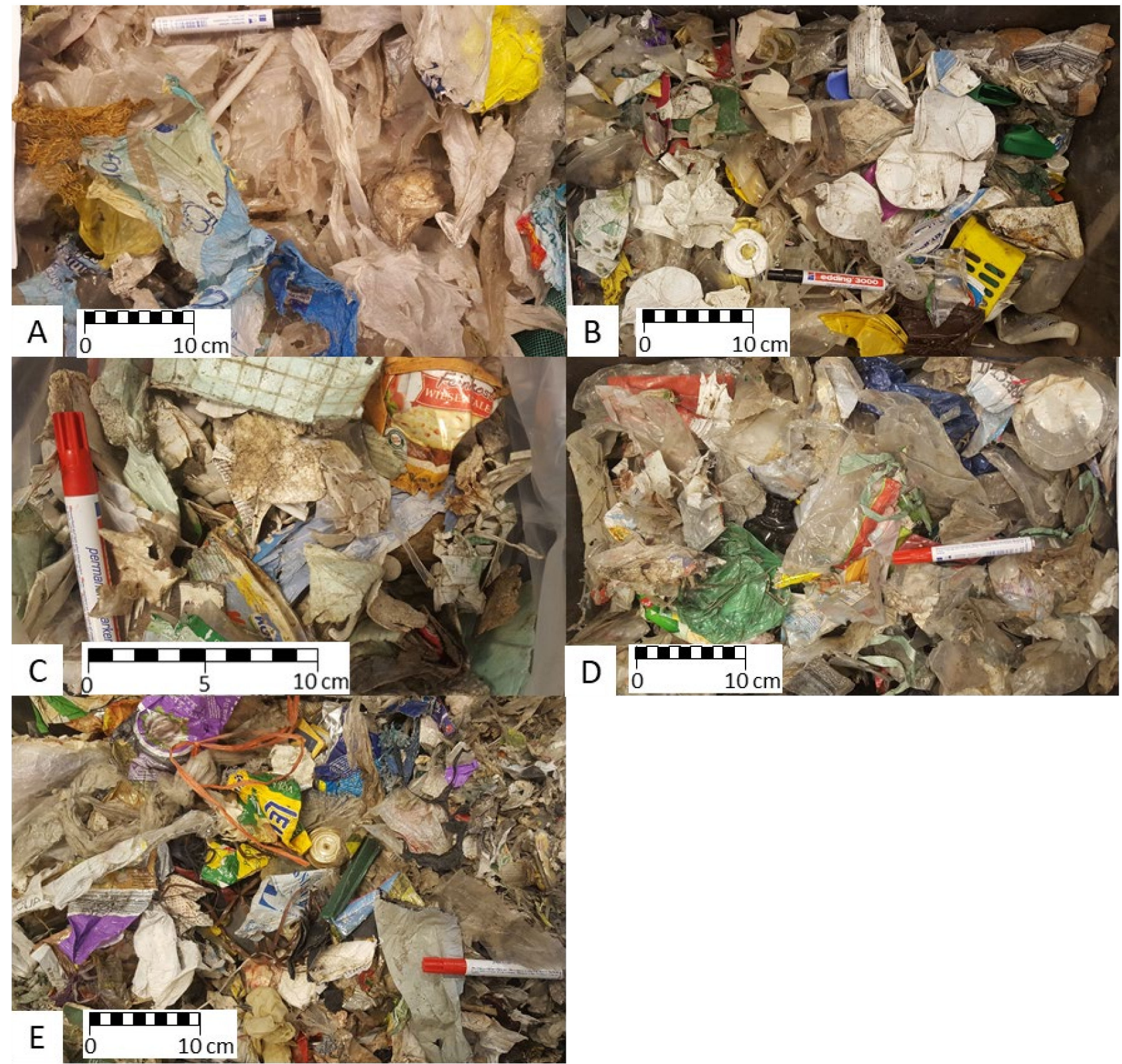

Figure A4. Exemplary photos of plastic types sorted with NIR: PE-A; PP-B; PET-C; PS-D; and others-E. 

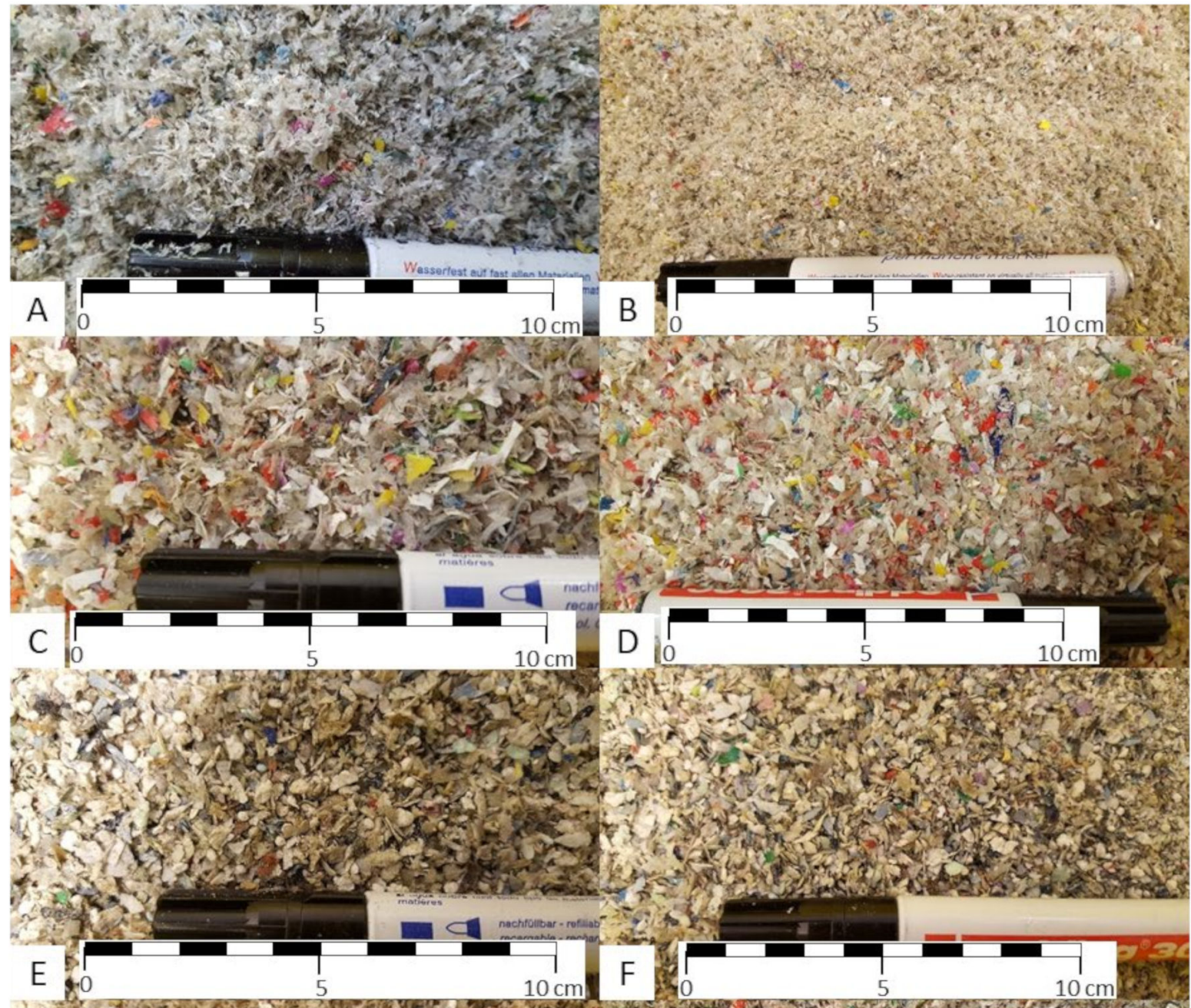

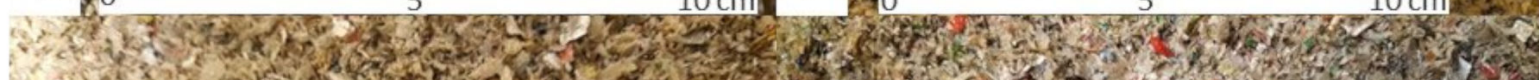

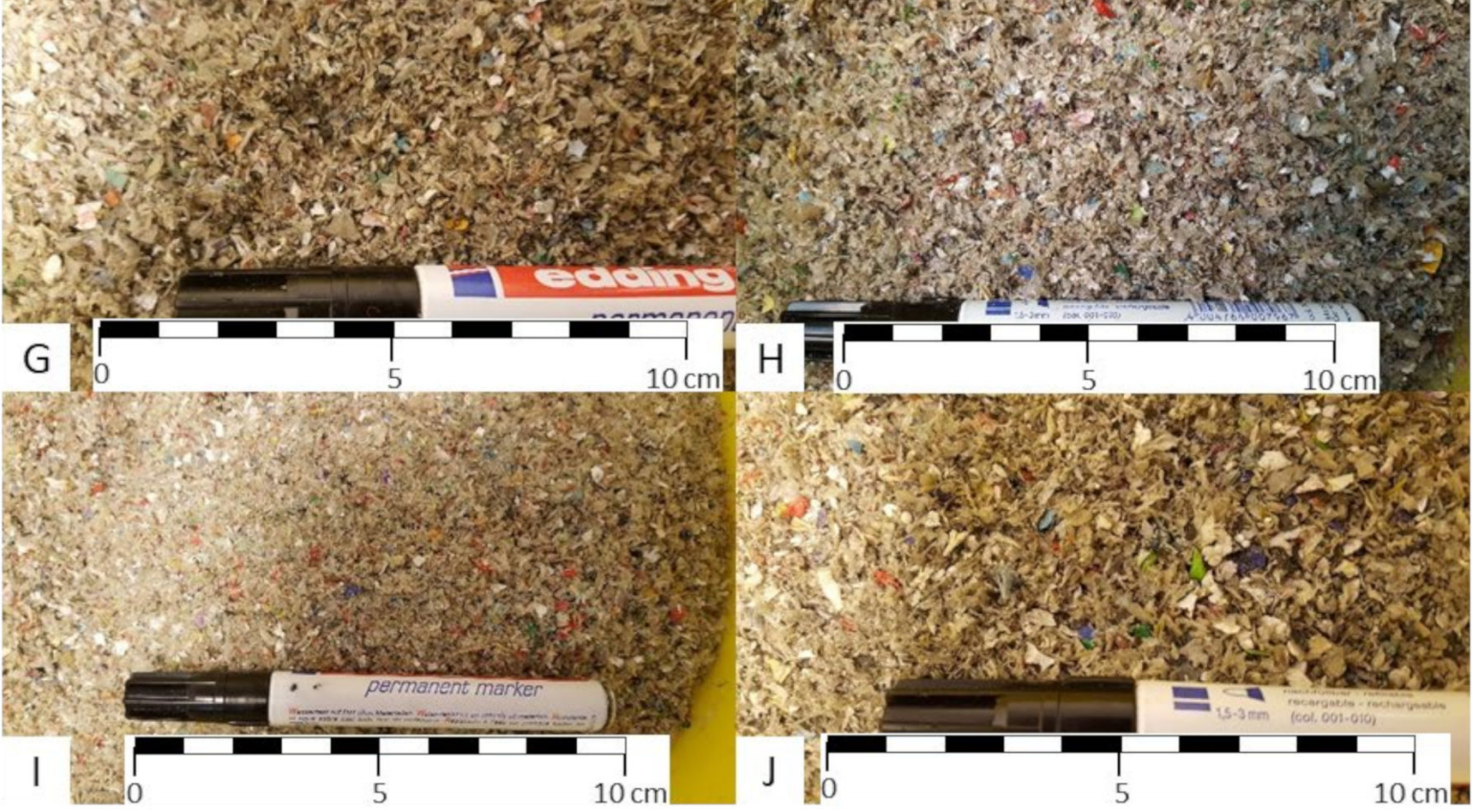

Figure A5. Exemplary photos of the flakes of all investigated materials after shredding to $<4 \mathrm{~mm}$ : $\mathrm{P} \_\mathrm{PE}-\mathbf{A} ; \mathrm{P}_{-} \mathrm{W}, \mathrm{PE}-\mathbf{B}$; P_PP-C; P_W,PP-D; P_PS-E; P_W,PS-F; PO_A-G; PO_W,A-H; PO_B-I; and P-J. 


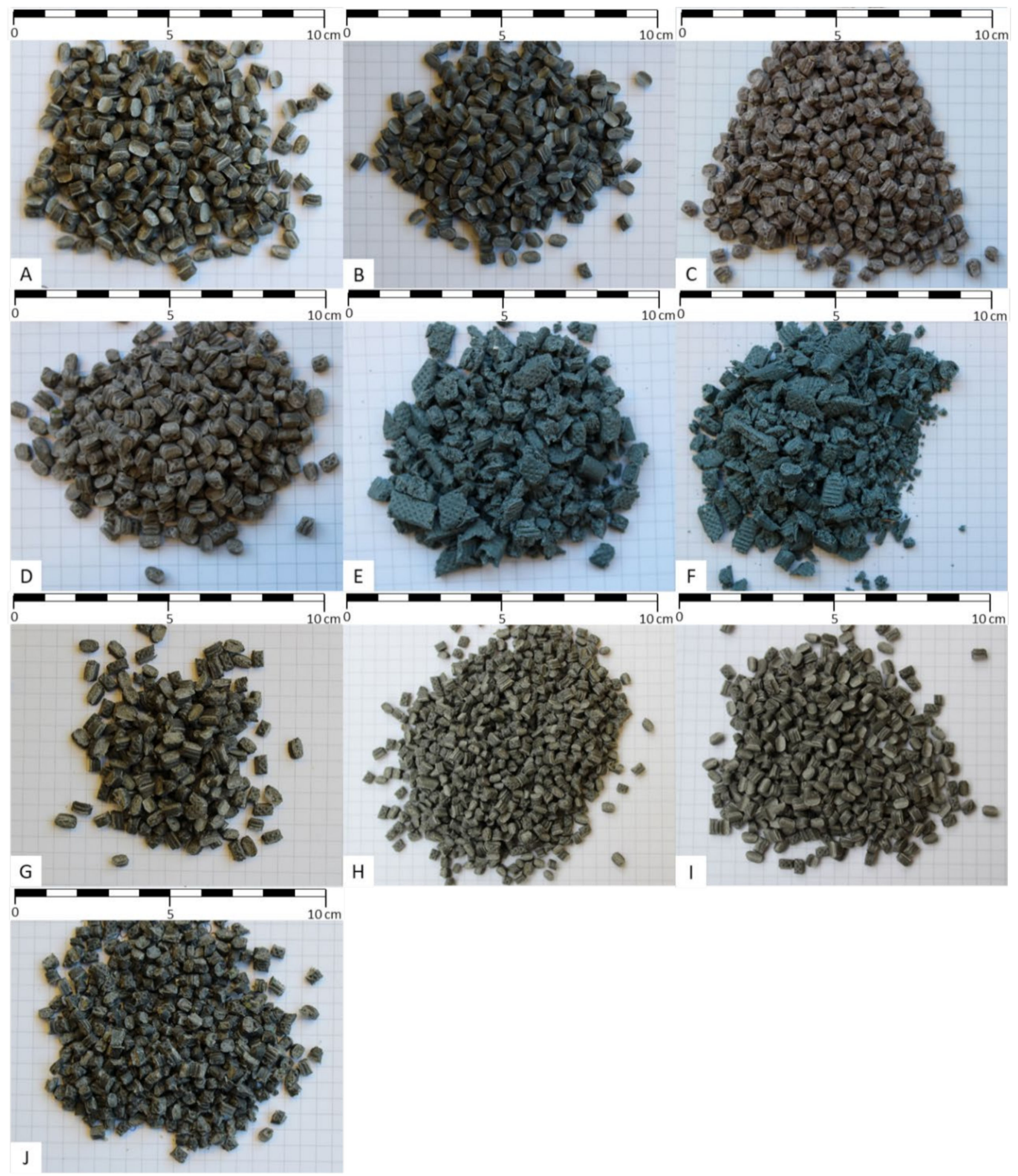

Figure A6. Exemplary photos of the granulates of all investigated materials after homogenisation and pelletising: $\mathrm{P} \_\mathrm{C}, \mathrm{PE}-$ A; P_W,C,PE-B; P_PP_C-C; P_W,C,PP-D; P_C,PS-E; P_W,C,PS-F; PO_A,C-G; PO_W,C,A-H; PO_B,C-I; and P_C - J. 


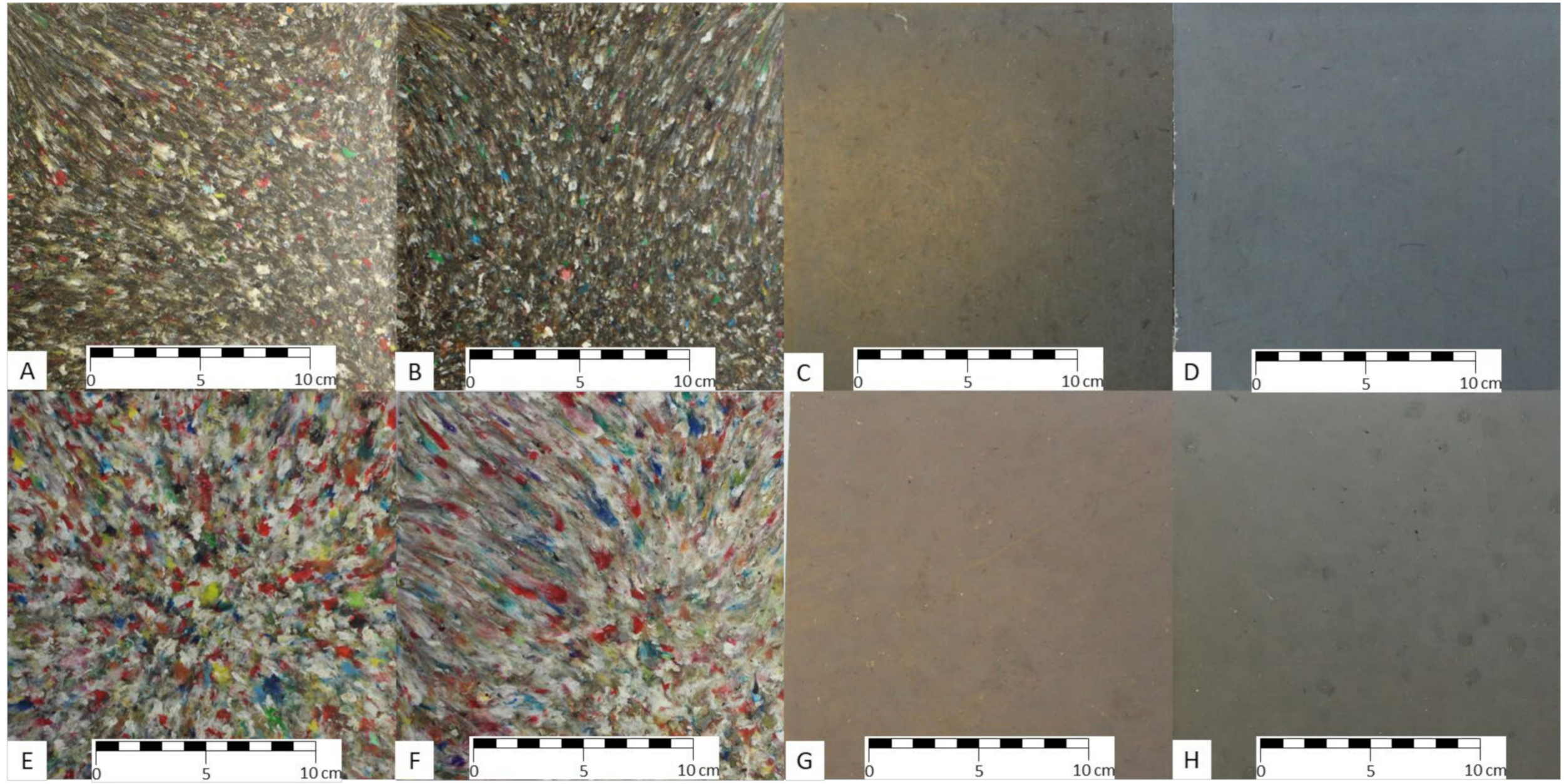

Figure A7. Exemplary photos of vacuum compression moulded plates: P_PE-A; P_W,PE-B; P_C,PE-C; P_W,C,PE—D; P_PP—E; P_W,PP—F; P_C,PP—G; and P_W,C,PP—H. 


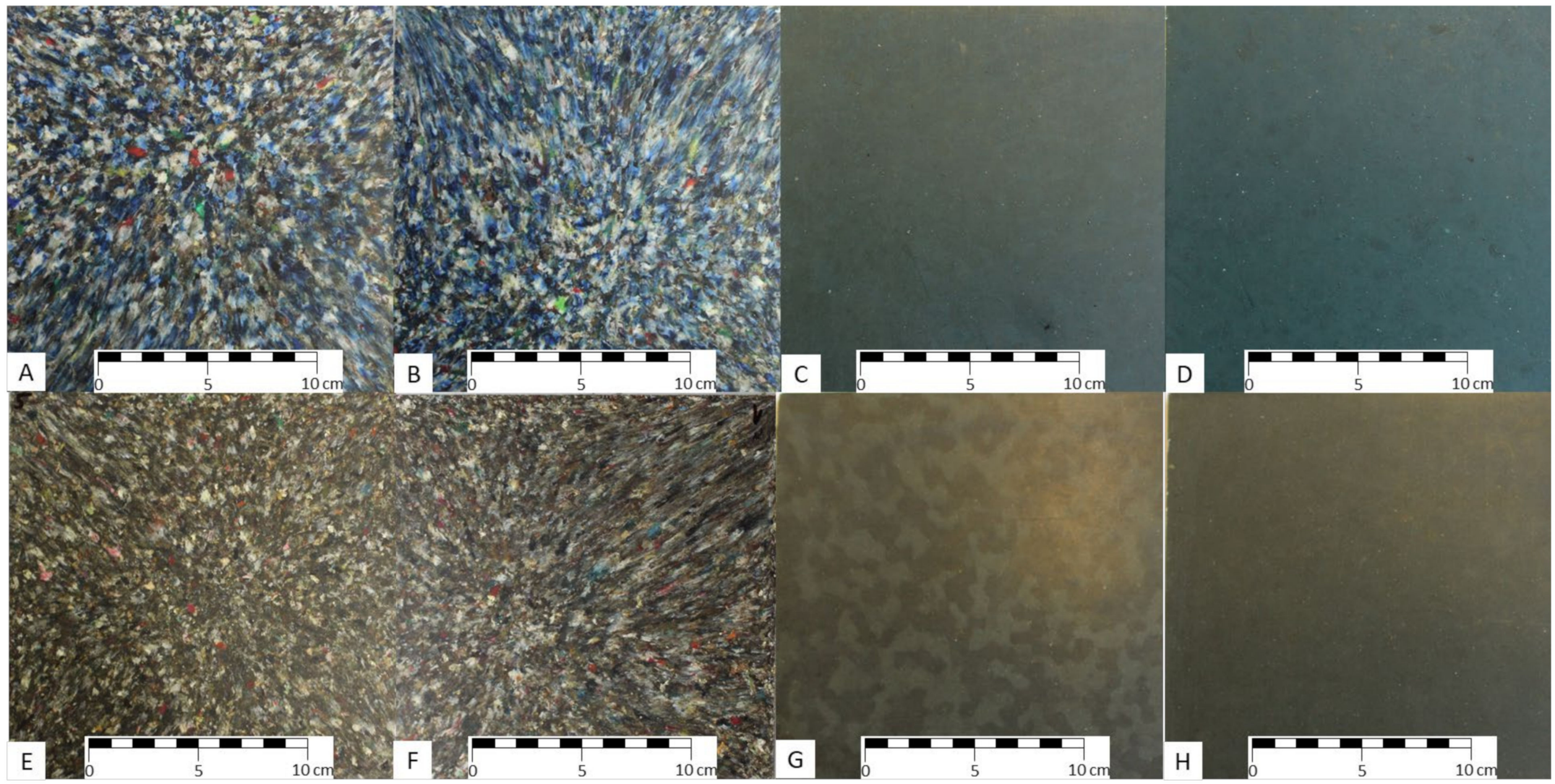

Figure A8. Exemplary photos of vacuum compression moulded plates: P_PS-A; P_W,PS-B; P_C,PS-C; P_W,C,PS-D; PO_A-E; PO_A,W-F; PO_A,C-G; and PO_A,W,C-H. 


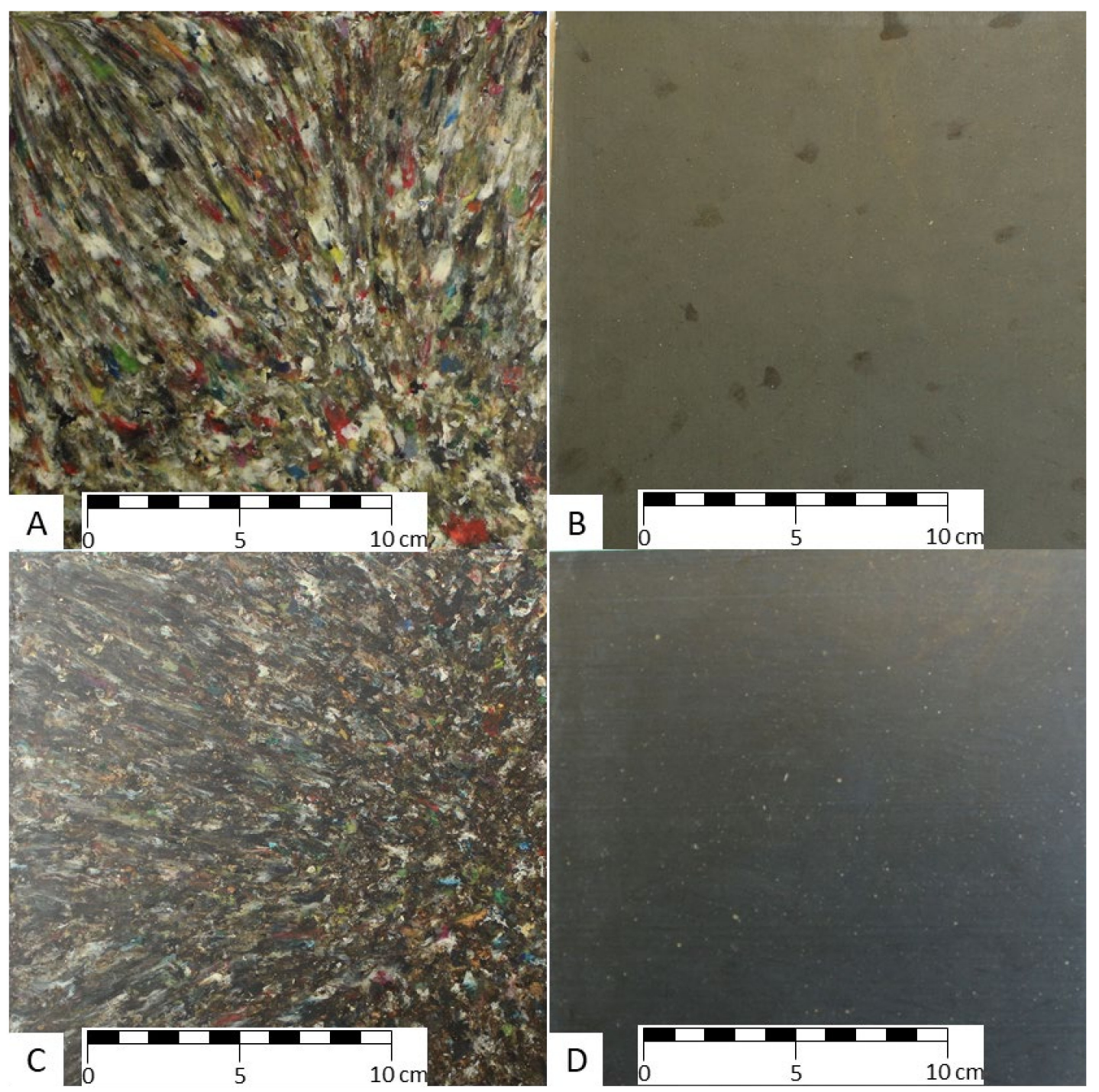

Figure A9. Exemplary photos of vacuum compression moulded plates: PO_B-A; PO_B,W-B; P-C; and P_C—D.

\section{Appendix J. Application Options}

Table A53. Possible applications for the materials investigated.

\begin{tabular}{|c|c|c|}
\hline Material & Processability & Potential Products for Application \\
\hline P_PE & compression moulding & $\begin{array}{l}\text { distribution pallets [33], bins, pails, roofing [36] and fencing [35] sheets [37], plates for } \\
\text { impact sound and thermal insulation, lawn stones }\end{array}$ \\
\hline P_W,PE & compression moulding & $\begin{array}{l}\text { distribution pallets [33], bins, pails, roofing [36] and fencing [35] sheets [37], plates for } \\
\text { impact sound and thermal insulation, lawn stones }\end{array}$ \\
\hline P_C,PE & extrusion & Round, square and flat profiles [38], sheets, plates for in-and outdoor applications \\
\hline P_W,C,PE & extrusion & Round, square and flat profiles [38], sheets, plates for in-and outdoor applications \\
\hline P_PP & compression moulding & $\begin{array}{l}\text { distribution pallets [33], bins, pails, roofing [36] and fencing [35] sheets [37], plates for } \\
\text { impact sound and thermal insulation, lawn stones }\end{array}$ \\
\hline P_W,PP & compression moulding & $\begin{array}{l}\text { distribution pallets [33], bins, pails, roofing [36] and fencing [35] sheets [37], plates for } \\
\text { impact sound and thermal insulation, lawn stones }\end{array}$ \\
\hline P_C,PP & extrusion & Round, square and flat profiles [38], sheets, plates for in-and outdoor applications \\
\hline P_W,C,PP & extrusion & Round, square and flat profiles [38], sheets, plates for in-and outdoor applications \\
\hline
\end{tabular}


Table A53. Cont.

\begin{tabular}{|c|c|c|}
\hline Material & Processability & Potential Products for Application \\
\hline P_PET & No processing possible & No application \\
\hline P_W,PET & No processing possible & No application \\
\hline P_C,PET & No processing possible & No application \\
\hline P_W,C,PET & No processing possible & No application \\
\hline P_PS & compression moulding & $\begin{array}{l}\text { roofing and fencing sheets, plates for thermal insulation, office equipment, cases, plant } \\
\text { pots, desk items [39] }\end{array}$ \\
\hline P_W,PS & compression moulding & $\begin{array}{l}\text { roofing and fencing sheets, plates for thermal insulation, office equipment, cases, plant } \\
\text { pots, desk items [39] }\end{array}$ \\
\hline P_C,PS & extrusion & Round, square and flat profiles [38], sheets, plates for in and outdoor applications \\
\hline P_W,C,PS & extrusion & Round, square and flat profiles [38], sheets, plates for in and outdoor applications \\
\hline PO_A & compression moulding & $\begin{array}{l}\text { distribution pallets [33], bins, pails, roofing [36] and fencing [35] sheets [37], plates for } \\
\text { impact sound and thermal insulation, lawn stones }\end{array}$ \\
\hline PO_A,W & compression moulding & $\begin{array}{l}\text { distribution pallets [33], bins, pails, roofing [36] and fencing [35] sheets [37], plates for } \\
\text { impact sound and thermal insulation, lawn stones }\end{array}$ \\
\hline PO_A,C & extrusion & Round, square and flat profiles [38], sheets, plates for in-and outdoor applications \\
\hline PO_A,W,C & extrusion & Round, square and flat profiles [38], sheets, plates for in- and outdoor applications \\
\hline PO_B & compression moulding & $\begin{array}{l}\text { distribution pallets [33], bins, pails, roofing [36] and fencing [35] sheets [37], plates for } \\
\text { impact sound and thermal insulation, lawn stones }\end{array}$ \\
\hline PO_B,C & extrusion & Round, square and flat profiles [38], sheets, plates for in-and outdoor applications \\
\hline $\mathrm{P}$ & compression moulding & $\begin{array}{l}\text { distribution pallets [33], bins, pails, roofing [36] and fencing [35] sheets [37], plates for } \\
\text { impact sound and thermal insulation, lawn stones }\end{array}$ \\
\hline P_C & extrusion & Round, square and flat profiles [38], sheets, plates for in-and outdoor applications \\
\hline
\end{tabular}

\section{References}

1. Ignatyev, I.A.; Thielemans, W.; Beke, B.V. Recycling of Polymers: A Review. ChemSusChem 2014, 7, 1579-1593. [CrossRef] [PubMed]

2. Ragaert, K.; Delva, L.; Van Geem, K. Mechanical and chemical recycling of solid plastic waste. Waste Manag. 2017, 69, 24-58. [CrossRef] [PubMed]

3. Al-Salem, S.M.; Lettieri, P.; Baeyens, J. Recycling and recovery routes of plastic solid waste (PSW): A review. Waste Manag. 2009, 29, 2625-2643. [CrossRef] [PubMed]

4. Plastics Europe. Plastics— the Facts 2020: An Analysis of European Plastics Production, Demand and Waste Data. Available online: https: / / www.plasticseurope.org/en/resources/publications/4312-plastics-facts-2020 (accessed on 16 December 2020).

5. Pomberger, R.; Sarc, R.; Lorber, K. Dynamic visualisation of municipal waste management performance in the EU using Ternary Diagram method. Waste Manag. 2017, 61, 558-571. [CrossRef] [PubMed]

6. Bauer, M.; Lehner, M. Post-consumer plastics in Austria and their potential for chemical recycling. In Proceedings of the ISWA World Congress, Vienna, Austria, 7-11 October 2013.

7. European Union (EU). Directive 2008/98/EC of the European Parliament and of the Council of 19 November 2008 on Waste and Repealing Certain Directives; European Union: Brussels, Belgium, 2018.

8. Federal Ministry for Climate Protection, Environment, Energy, Mobility, Innovation and Technology. Die Bestandsaufnahme der Abfallwirtschaft in Österreich-Statusbericht 2020 (Referenzjahr 2018); Federal Ministry for Climate Protection, Environment, Energy, Mobility, Innovation and Technology: Vienna, Austria, 2020. Available online: https://www.bmk.gv.at/en/topics/climateenvironment.html (accessed on 30 December 2020).

9. Friedrich, K.; Möllnitz, S.; Holzschuster, S.; Pomberger, R.; Vollprecht, D.; Sarc, R. Benchmark Analysis for Plastic Recyclates in Austrian Waste Management. Detritus 2019, 9, 105-112. [CrossRef]

10. Letcher, T.M. Platic Waste and Recycling_Environmental Impact, Societal Issues, Prevention, and Solutions; Elsevier: London, UK, 2020.

11. Austrian Standards Institute. ÖNORM S 2123-3: Sampling Plans for Waste—Part 3: Sampling of Solid Waste out of Material Streams; Austrian Standards Institute: Vienna, Austria, 2003.

12. Bauer, M.; Lehner, M.; Schwabl, D.; Flachberger, H.; Kranzinger, L.; Pomberger, R.; Hofer, W. Sink-float density separation of post-consumer plastics for feedstock recycling. J. Mater. Cycles Waste Manag. 2018, 20, 1781-1791. [CrossRef]

13. Wunderlich, B. Materials Properties. Structure and Properties of Materials. In Thermal Analysis of Polymeric Materials; Springer: Berlin/Heidelberg, Germany, 2005; pp. 512-516. 
14. Van Krevelen, D.W.; te Nijenhuis, K. Properties of Polymers:Their Correlation with Chemical Structure; Their Numerical Estimation and Prediction from Additive Group Contributions, 4th ed.; Elsevier: Amsterdam, The Netherlands, 2008.

15. DIN EN ISO 11357-1:2016. Plastics_Differential Scanning Calorimetry (DSC) Part 1: General Principles; Beuth: Berlin, Germany, 2017.

16. DIN EN ISO 179-1:2010. Plastics—Determination of Charpy Impact Properties_Part 1: Non-Instrumented Impact Test; Beuth: Berlin, Germany, 2011.

17. Austrian Standards Institute (ASI). ÖNORM EN ISO 527-1:2012 05 15: Plastics—Determination of Tensile Properties—Part 1: General Principles; Beuth: Vienna, Austria, 2012.

18. Austrian Standards Institute (ASI). ÖNORM EN ISO 527-2:2012 05 15: Plastics—Determination of Tensile Properties—Part 2: Test Conditions for Moulding and Extrusion Plastics; Beuth: Vienna, Austria, 2012.

19. DIN EN ISO 3451-1:2019. Plastics—Determination of ash-Part 1: General Methods; Beuth: Berlin, Germany, 2019.

20. DIN EN ISO 60:1999. Plastics_Determination of Apparent Density of Material That Can Be Poured from a Specified Funnel; Beuth: Berlin, Germany, 2000.

21. DIN EN ISO 1133-1:2011. Plastics-Determination of the Melt Mass-Flow Rate (MFR) and Melt Volume-Flow Rate (MVR) of Thermoplastics_-Part 1: Standard Method; Beuth: Berlin, Germany, 2012.

22. Sarc, R.; E Lorber, K.; Pomberger, R.; Rogetzer, M.; Sipple, E.M. Design, quality, and quality assurance of solid recovered fuels for the substitution of fossil feedstock in the cement industry. Waste Manag. Res. 2014, 32, 565-585. [CrossRef] [PubMed]

23. Ehrenstein, G.W.; Theriault, R.P. Thermomechanical Properties. In Polymeric Materials: Structure, Properties, Applications; Hanser: Munich, Germany, 2001; pp. 143-165.

24. Domininghaus, H.; Elsner, P.; Eyerer, P.; Hirth, T. Thermoplastische Polymere. In Kunststoffe—Eigenschaften und Anwendungen, 7th ed.; Springer: Berlin/Heidelberg, Germany, 2012; pp. 163-629.

25. Karger-Kocsis, J. Crystalline structures of polypropylene homo and copolymers. In Polypropylene Structure, Blends and CompositesVolume 1 Structure and Morphology; Springer: Berlin, Germany, 1995; pp. 31-56.

26. Ehrenstein, G.W.; Riedel, G.; Trawiel, P. Grundlagen der Dynamischen Differenzkaloriemetrie. In Praxis der Thermischen Analyse von Kunststoffen, 2nd ed.; Hanser: Munich, Germany, 2003; pp. 1-35.

27. Koltzenburg, S.; Maskos, M.; Nuyken, O. Polymere: Synthese, Eigenschaften und Anwendungen; Springer: Berlin, Germany, 2014.

28. Pina-Estany, J.; García-Granada, A.A. Computational analysis of polymer molecular structure effect on nanocavities replication via injection moulding. Afinidad Barc. 2018, 75, 3-8.

29. Kies, T. Entwicklung und Anwendung Eines Technologischen Vergleichsverfahrens zur Abschätzung der Verarbeitungseigenschaften von Thermoplast-Recyclaten beim Spritzgießen [Development and Application of a Technological Comparison Method for Estimating the Processing Properties of Thermoplastic Recyclates during Injection Moulding]. Ph.D. Thesis, Martin-LutherUniversität Halle-Wittenberg, Halle-Wittenberg, Germany, 2002.

30. Moll, S. Untersuchung der Auswirkungen einer Thermisch-oxidativen Beanspruchung auf das Emissionsverhalten von ABS und PP und der Korrelation mit dem Alterungsgrad [Investigation of the Effects of Thermal Oxidative Stress on the Emission Behaviour of ABS and PP and the Correlation with the Degree of Ageing]. Ph.D. Thesis, Friedrich-Alexander-Universität Erlangen-Nürnberg, Erlangen-Nürnberg, Germany, 2017.

31. Grellmann, W.; Seidler, S. Kunststoffprïfung-2. Auflage; Carl Hanser: Munich, Germany, 2011.

32. Shrivastava, A. Chapter 3-Plastic Properties and Testing. In Introduction to Plastics Engineering, Plastics Design Library; William Andrew Publishing: Oxford, UK, 2018; pp. 49-110.

33. Mark, J.E. Physical Properties of Polymers Handbook, 2nd ed.; Springer Science+Business Media: New York, NY, USA, 2007.

34. Retting, W. Chapter: Verformungs- und Bruchverhalten von Kunststoffen. In Mechanik der Kunststoffe: Die Mechanischen Eigenschaften von Polymer-Werkstoffen; Hanser: Munich, Germany, 1991; pp. 44-62.

35. Verdu, J. Effect of Aging on the Mechanical Properties of Polymeric Materials. J. Macromol. Sci. Part A 1994, 31, 1383-1398. [CrossRef]

36. Oswald, T.A. Understanding Polymer Processing_Processes and Governing Equations; Carl Hanser: Munich, Germany, 2017.

37. TranPak Inc. Proteus Distribution Pallet. Available online: https://www.tranpak.com/wp-content/uploads/2019/02/114218 SPEC-48x48.pdf (accessed on 24 January 2021).

38. IndiaMART. Recycled Plastic Roofing Sheet. Available online: https://www.indiamart.com/proddetail/recycled-plastic-roofingsheet-16254450733.html (accessed on 24 January 2021).

39. RictonPanels. Ricton Corrugated Eco-Fence. Available online: https://pdf.indiamart.com/impdf/22365236291/MY-22045255 / corrugated-eco-fencing.pdf (accessed on 24 January 2021). 